\title{
Recent Advances in Plant Responses to Stress: Bridging the Gap between Science and Technology
}

\author{
held at the \\ 91st ASHS Annual Meeting \\ Corvallis, Ore. \\ 7 Aug. 1994
}

\author{
sponsored by the \\ Environmental Stress Physiology Working Group \\ Developmental Physiology Working Group \\ Genetics and Germplasm Working Group \\ Growth Regulators in Fruit and Nut Production Working Group \\ Postharvest Working Group \\ Root Growth and Rhizosphere Dynamics Working Group \\ Water Utilization and Management Working Group \\ Mineral Nutrition Working Group \\ Plant Dormancy Working Group
}

published by the

American Society for Horticultural Science

Alexandria, VA 22314-2824

as a special insert in

HortScience 31(1), February 1996 


\title{
Colloquium Papers and Authors
}

\section{Presiding: Michael Wisniewski}

Recent Advances in Plant Responses to Stress: Bridging the Gap between Science and Technology: Introduction to the Colloquium

Michael Wisniewski

Recent Advances in Plant Response to Mechanical Stress: Theory and Application

Cary A. Mitchell

Regulation of Plant Growth Responses to Low Soil Water Potentials

Robert E. Sharp

Low-temperature Stress Tolerance: The Role of Abscisic Acid, Sugars, and Heat-stable Proteins

L.V. Gusta, R.W. Wilen, and P. Fu

Theory and Application of Genetic Engineering for Stress Resistance and Avoidance

Steven E. Lindow

Role of Calcium in Plant Responses to Stresses: Linking Basic Research to the Solution of Practical Problems

Jiwan P. Palta

\section{Recent Advances in Plant Responses to Stress: Bridging the Gap between Science and Technology: Introduction to the Colloquium}

\author{
Michael Wisniewski \\ U.S. Department of Agriculture, Agricultural Research Service, Appalachian Fruit Research Station, \\ Kearneysville, WV 25430
}

\begin{abstract}
In nature, all plants are exposed to environmental conditions and biotic influences that reduce their potential growth. The impact of nonoptimal growing conditions on plants is referred to as environmental and biotic stress. As a stress is imposed, plants usually exhibit a cascade of responses, occurring on different time scales, that involve biochemical and morphological adjustments leading to stress tolerance or avoidance (Mooney et al., 1991). Plant stress, because of its impact on growth and reproductive output, plays a significant role in limiting crop production. Consequently, considerable research has been devoted to understanding basic mechanisms underlying the response of plants to stress. As noted by Close and Bray (1993), it is especially challenging to identify the stress responses that might be exploited to improve plant production in limiting environments.

In the past two decades, the field of plant stress has become a major subdiscipline within plant biology, and many basic and applied research goals have been reached. This colloquium is intended to review recent advances in our basic knowledge of plant adaptation to stress and the efforts to develop specific management practices that either attempt to moderate detrimental stress responses or, alternatively, use stress to horticultural advantage. This colloquium is not intended to be a comprehensive review, but rather to highlight the accumulation of
\end{abstract}

Received for publication 25 May 1995. Accepted for publication 24 July 1995. The cost of publishing this paper was defrayed in part by the payment of page charges. Under postal regulations, this paper therefore must be hereby marked advertisement solely to indicate this fact. new knowledge in specific areas and the beneficial application of that knowledge in the real world.

As attitudes regarding government-supported research change and the need for fiscal responsibility increases, funding for plant research is becoming more difficult to obtain. As horticulturists, we are becoming more adept at communicating the economic importance of our research to agricultural production. That is why this colloquium has been subtitled, "Bridging the Gap Between Science and Technology." As scientists, we have to be concerned more than ever before about the application of our knowledge. Patents, technology transfer, research and development grants, biotechnology, all these terms are becoming an integral part of our professional vernacular. With this in mind, our contributors were asked, wherever possible, to indicate how our basic knowledge of plant stress has led to the development of new technology or management practices that maintain or increase agricultural production.

Cary Mitchell reviews recent advances in our understanding of how plants respond to mechanical stress (seismic and thigmic). Although an appreciation of the impact of this type of stress on plant growth and development has been slow to develop, Mitchell will clearly illustrate the commercial potential of regulating plant growth under greenhouse conditions in a beneficial manner via the use of physical pertubations. He will also address how the discovery of "touch genes" in plants has led to a more fundamental understanding of signal transduction in plants.

Robert Sharp discusses the response of plants to low soil water 
potentials. In particular, he discusses the role of abscisic acid in regulating root growth and its possible role as a "root signal" that inhibits leaf growth in the absence of leaf water deficits.

Larry Gusta and coauthors present a comprehensive review of lowtemperature stress tolerance in plants, covering recent advances in our basic knowledge, attempts to use growth regulators to enhance freezing tolerance, and the potential of using genetic engineering to produce genotypes with increased cold hardiness.

Steven Lindow presents an overview of the theory and application of genetic engineering to alter plants in innovative ways as a means to confer resistance or tolerance to biological and abiotic stresses. In particular, he will give an insightful summary of the contrasting activities of industry vs. public research institutions in the area of biotechnology.

Last, Jiwan Palta discusses the role of $\mathrm{Ca}$ in plant responses to environmental and biotic stress. He will also describe how the appli- cation of this knowledge has led to the development of innovative cultural practices designed to alleviate stress-related production problems in the Wisconsin potato industry. In my estimation, the contributors have done an excellent job in reviewing the important advances that have been made in the area of plant stress biology and in demonstrating that this knowledge has practical application in enhancing agricultural production via the development of new management practices and the introduction of new stress-resistant genotypes.

\section{Literature Cited}

Close, T.J. and E.A. Bray (eds.). 1993. Plant responses to cellular dehydration during environmental stress. Amer. Soc. Plant Physiol., Rockville, Md.

Mooney, H., W.E. Winner, and E.J. Pell (eds.). 1991. Response of plants to multiple stresses. Academic, San Diego.

\title{
Recent Advances in Plant Response to Mechanical Stress: Theory and Application
}

\author{
Cary A. Mitchell \\ Center for Plant Environmental Stress Physiology, Department of Horticulture, Purdue University, West Lafayette, \\ IN 47907-1165
}

\section{APPRECIATION OF MECHANICAL SENSITIVITY IN PLANTS}

The sensitivity of plants to mechanical stress long was regarded as an artifact of the plant hardening response to extreme environments (Klickoff, 1965), as a curiosity of specialized plants adapted for insectivory (Ball, 1926), or as an avoidance of grazing herbivores (Toriyama, 1955). Mechanical stress vectors of nature include wind, rain, hail, and animal movements. Production agriculture and landscape practices provide further physical insults to plants in the form of pruning, pinching, tying, guying, and trimming. Urban high-rise buildings create air turbulence and downdrafts that permanently entrain trees and shrubs to growth habits reminiscent of natural plants inhabiting seacoasts and mountain slopes. Appreciation for wind per se as a powerful factor limiting plant development has been slow to develop. It is easy to overlook the mechanical aspect of wind and precipitation on plant form and growth habit because they are not always present and because many environmental stress factors coexist with wind in the outdoor environment (Mitchell et al., 1975). The influences of other environmental stress factors on plants often mask or negate the influence of mechanical stress. Confounding natural factors include airborne sea salt, desiccation, and evaporative chilling, all of which accompany wind (Mitchell, 1977b). Only if controlled mechanical stresses (e.g., shaking, handling, flexing) are applied to plants growing in the wind-protected confines of a greenhouse or growth chamber is it possible to separate effects of mechanical stress per se from those of other environmental stresses, such as heat, cold, drought, flooding, and/or mineral deficiencies. It is surprising how sensitive plant growth can be to brief episodes of mechanical stress, especially if the plants are grown otherwise undisturbed in a stress-free environment. The general effect of shaking plants is retardation of internode elongation and inhibition of leaf expansion, which dwarfs plants in size and mass, depending on the dose of stress received (Fig. 1). Plant growth and developmental responses to shaking have been described as "seismomorphism," and the process as

Received for publication 25 May 1995. Accepted for publication 24 July 1995. Journal paper no. 14521 of the Purdue Univ. Agricultural Experiment Station. The cost of publishing this paper was defrayed in part by the payment of page charges. Under postal regulations, this paper therefore must be hereby marked advertisement solely to indicate this fact. "seismomorphogenesis" (Mitchell et al., 1975). The term "thigmomorphogenesis" describes developmental changes resulting from contact rubbing (Jaffe, 1973). The defining characteristics of thigmomorphism are internode compression and lateral enlargement (i.e., swelling) of stems. Plant responses to seismic stress tend to be similar, but not always identical, to those of thigmic stress (Heuchert et al., 1983).

\section{CONTROLLED APPLICATION OF MECHANICAL STRESS}

When the branch tips of potted chrysanthemums [Dendranthema $\times$ grandiflorum (Ramat.) Kitamura] were manually flexed for a few seconds each day, the plants grew much more slowly than did untouched controls (Hammer et al., 1974). Flowers of the shorter, stressed plants were not smaller, but the smaller plants required much less water than the taller controls, which had more transpiring leaf surface. Shaking, upper stem flexure, or both could be an alternative to use of chemical growth retardants, but growers cannot afford the labor to manually tweak every plant on a greenhouse bench one or more times daily. To standardize application of seismic treatments for research, laboratory shakers can be modified with platforms to accommodate several plants (Mitchell, 1977b), but growers still cannot afford to manually load and unload a limited number of platform shakers. Thus, a series of automated mechanical oscillatory shaking (AMOS) devices were built at Purdue Univ. in the mid-1970s to serve as a prototype for shaking devices with potential commercial application (Beyl and Mitchell, 1977a). Research on height control of chrysanthemum using AMOS revealed that early morning was the most effective time for shaking, and that seismomorphism obeys the law of reciprocity (Beyl and Mitchell, 1977b). Brief, daily shaking of 'Alaska' pea (Pisum sativum L.) plants on a gyratory platform shaker not only dwarfed the plants, but also decreased the number of pods formed as well as the number of seeds per pod (Akers and Mitchell, 1984). The combined effect was that seed yield of shaken pea plants was only half that of undisturbed controls. Every crop species examined thus far has undergone some kind of yield reduction from mechanical stress, due either to a delay in flowering or to a decrease in size, number, or mass of harvestible parts (Akers and Mitchell, 1985). Stroking the stem tips (thigmic stress) or shaking the entire shoot (seismic stress) of potted potato (Solanum tuberosum $\mathrm{L}$.) plants led to a decrease in the size and 


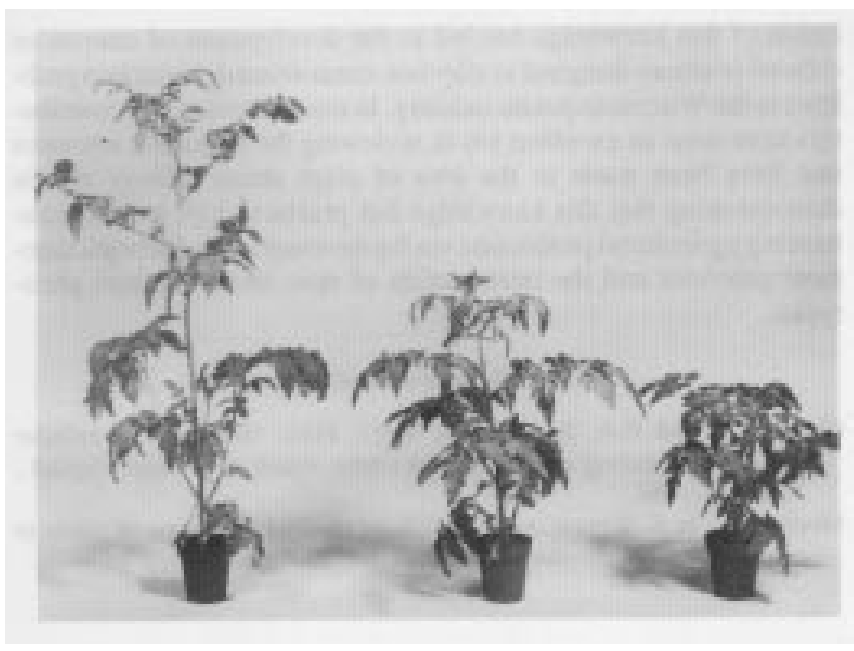

Fig. 1. Seismomorphism of 'Bonny Best' tomato plants after 28 consecutive days of mechanical stress treatment in a greenhouse. All three plants were the same size and age at initiation of seismic treatment, and all three received subirrigation throughout the treatment period. Treatments included (left) undisturbed control, (center) $30 \mathrm{sec}$ of horizontal gyratory shaking at $282 \mathrm{rpm}$ once daily, and (right) $30 \mathrm{sec}$ of shaking twice daily (Mitchell et al., 1975).

mass, but not the number, of tubers formed during treatment (Mitchell, 1992). The outcome of mechanical stress experiments with potato suggests that shoots, which receive the primary mechanical stress stimuli, are able to communicate those signals to below-ground plant parts. The fact that localized rubbing of stem tips has the same growthretarding effects on potato tubers as more general shaking treatments applied to the entire shoot weakens any argument that stress effects on roots and tubers are caused merely by transmission of physical forces within plant tissues from shoots to below-ground plant parts.

\section{ENVIRONMENTAL MODIFICATION OF MECHANICAL STRESS SENSITIVITY}

\section{Seasonality}

Not all mechanical stress effects on plants are negative. Herbaceous species growing in a greenhouse under the low light conditions of winter typically elongate and develop weak stems. Soybean (Glycine max Merr.), tomato (Lycopersicon esculentum Mill.), and potato stems assume a vining growth habit under such conditions. However, touching, shaking, or vibrating plants a few seconds per day is all that is needed to keep the stems of all three species growing strong and erect during the winter (Heuchert and Mitchell, 1983). The modulus of elasticity of tomato stem and petiole tissue was lower during the winter than during the summer (Heuchert et al., 1983). Periodic shaking enhanced stem elasticity during the winter but not during the summer. Nonoptimal environmental conditions likely raise the threshold of plant response to mechanical stress. At least during the winter, increasing intensity of shaking treatments enhanced the cellulose component of tomato stem fiber, which contributes to stem flexibility. In fact, the stems of tomato plants that have been shaken for a few seconds each day for several weeks become so fibrous that they can be bent into a horseshoe shape, then a reverse horseshoe shape, and even straightened once again. In contrast, the stems of undisturbed control plants are so brittle that they snap if bent slightly from vertical.

\section{Temperature}

One clue regarding the seasonal nature of mechanical stress sensitivity may come from the stress response/temperature profile of bean (Phaseolus vulgaris L.) stem growth (Jaffe, 1976a). Between 20 and $30 \mathrm{C}$, maximum growth reduction occurs at $24 \mathrm{C}$. Even though the plants were almost insensitive to rubbing at 20 or 30C, growth of unstressed plants continued at those temperatures. Each species likely has its own temperature range for optimum mechanical stress sensitivity. One can readily appreciate how easily temperature could leave the optimal range for mechanical stress response in a summer or winter greenhouse.

\section{Light level}

The other logical difference between winter and summer is maximum intensity and daily dosage of sunlight available to support plant growth. When soybean plants were grown at various levels of shading in a controlled environment, sensitivity to mechanical stress was inversely proportional to the level of light at which the plants were grown (Jones et al., 1990). At photosynthetic photon fluxes $>300$ $\mu \mathrm{mol} \cdot \mathrm{m}^{-2} \cdot \mathrm{s}^{-1}$, soybean growth was hardly affected by a vigorous daily shaking regime. Internodes were compressed and leaves were enlarged for both control and seismic stress treatments. With $25 \%$ shading, the dwarfing response to stress was a bit more evident, and even more at $50 \%$ shading. At $75 \%$ shading, not only was the stress response evident, but also the spindly plant syndrome for undisturbed controls. Soybeans growing in the field seem to be relatively insensitive to mechanical perturbation, or have they merely become hardened to a given level of physical stress? The threshold of mechanical stress sensitivity likely is higher for outdoor-grown plants than for greenhouse plants, and it takes a higher intensity or duration of shaking to dwarf outdoor plants to the same extent as greenhouse plants.

\section{HEIGHT CONTROL AND CONDITIONING OF TRANSPLANTS}

Experiments investigated the commercial potential for exploiting the use of shoot "brushing" to condition tender greenhouse seedlings to the outdoor environment (Latimer, 1991b). Brushing reduced stem length, leaf area, and shoot dry weight of various vegetable transplants $25 \%$ to $43 \%$, depending on when treatment was initiated before transplanting outdoors. Unlike drought-stressed transplants, brushed ones resume normal growth within 3 days after treatment is stopped (Latimer and Beverly, 1993). Brush-preconditioned seedlings survived transplant shock in the field better than unbrushed controls (Latimer et al., 1991). An adjustable height guide for a brush pole across a bench with slide channels on either side of the bench has been tested brushing an entire bench of transplants, accomplished by an operator in minutes (Latimer, 1991a). One potential disadvantage of contact methods for stress application is that resulting shoot tissue abrasion may provide a ready avenue for pathogen invasion. This limitation might be circumvented by methods that apply mechanical vibration, shaking action, or air currents to entire benches of transplants. Although there have been claims that mechanical stress improves cold and drought tolerance of plants (Jaffe and Biro, 1979), evidence supporting this interpretation is not strong. One of the main advantages of mechanical conditioning is that it strengthens stems and petioles. Another is that brushing does not have long-term retarding effects on plant development, whereas severe drought stress does. A combination of brushing and mild drought stress may hold the best promise for low-cost, chemical-free conditioning of vegetable transplants.

\section{STIMULATING PLANT GROWTH}

Several studies have shown that low-amplitude mechanical vibration in the frequency range of 50 to $60 \mathrm{~Hz}$ actually stimulates rather than inhibits cumulative plant growth (Takahashi et al., 1991). Such vibration for $30 \mathrm{~min}$ each hour for 7 days stimulated growth in size and mass of tomato seedlings $10 \%$ to $15 \%$ after 10 days of treatment (Akers and Mitchell, 1980). Mild growth stimulation occurred in various horticultural and agronomic crops after vibrating or slowly shaking them almost continuously (M. Cuellar, T. Pappas, J. Latimer, and C. Mitchell, unpublished). Japanese growers apply vibration, and even music, below benches and position speakers in contact with components of commercial hydroponic culture systems (Tohoku Pioneer Electronic Corp., Tendo, Japan). The vibroacoustic frequencies are claimed to stimulate photosynthesis, crop growth, and yield. 


\section{EFFECTS ON PHOTOSYNTHETIC PRODUCTIVITY}

Less frequent episodes of seismic stress are much more effective for inhibiting photosynthetic productivity than is continuous stimulation (Pappas and Mitchell, 1985a). Soybean plants shaken for only a few seconds once or twice daily became proportionately dwarfed copies of undisturbed controls. A mild reduction in net assimilation rate (NAR) by shaken soybean plants was not quite offset by a compensatory increase in leaf area ratio (LAR). The resulting modest reduction in relative growth rate (RGR) according to the relationship RGR $=$ NAR $\times$ LAR caused a lag in cumulative growth of seismostressed plants that was compounded each day stress was applied. These decrements of lagging growth quickly added up to retarded growth in biomass, photosynthetic surface, and plant size. To determine what contributes to the stress-induced decrease in NAR, net photosynthesis was measured within a whole-plant, gas-exchange cuvette while the entire cuvette and its plant contents were shaken (Pappas and Mitchell, 1985b). Net carbon assimilation dropped within minutes of the onset of a brief shaking episode, and it took at least 40 min for photosynthesis to recover to the rate of nonstressed controls. Leaf resistance analysis indicated that stomatal resistance for $\mathrm{H}_{2} \mathrm{O}$ vapor and $\mathrm{CO}_{2}$ diffusion increased $20 \mathrm{~min}$ after a brief shaking episode, especially on lower leaf surfaces. In contrast, mesophyll resistance was unaffected by shaking. Thus, the combination of retarded expansion of new leaves plus the temporary reduction in stomatal aperture for expanded leaves contributed to the lighter mass of shaken soybean plants over time.

\section{EVIDENCE FOR HORMONAL INVOLVEMENT}

Observations that mechanical stress responses of plants are dose dependent (Jaffe, 1976a), that the responses are saturable (Beyl and Mitchell, 1977b), and that one or more morphogenetic stimuli are transmissible from physically disturbed plant parts to nondisturbed parts (Erner et al., 1980) have been taken as evidence for hormonal mediation. Furthermore, many symptoms of seismo- and thigmomorphogenesis can be either mimicked or antagonized by chemical agents, including exogenous hormones (Biro and Jaffe, 1984; Boyer et al., 1983; Erner and Jaffe, 1982).

\section{Ethylene}

Ethylene $\left(\mathrm{C}_{2} \mathrm{H}_{4}\right)$, the so-called "stress hormone," has received the most attention of all the phytohormones with respect to mechanical stress growth regulation. Inhibition of stem elongation, stem swelling, loss of gravitropic sensitivity (Goeschl et al., 1966), and leaf epinasty (Jaffe, 1973) all are reported actions of $\mathrm{C}_{2} \mathrm{H}_{4}$ or mechanical stress. Furthermore, mechanically stressed plants release $\mathrm{C}_{2} \mathrm{H}_{4}$ at an elevated rate following a 1-h lag (Biro and Jaffe, 1984). However, increased activity of the enzyme 1-aminocyclopropane-1-carboxylic acid (ACC) synthase, which catalyzes production of the immediate precursor of $\mathrm{C}_{2} \mathrm{H}_{4}$, begins within $30 \mathrm{~min}$ of a stress episode. Treatments known to inhibit $\mathrm{C}_{2} \mathrm{H}_{4}$ synthesis or action also prevent certain plant responses to mechanical stress. For example, cobalt blocks the conversion of ACC to $\mathrm{C}_{2} \mathrm{H}_{4}$ (Boyer et al., 1986). Lithium, a suppressor of cell-wall-bound peroxidases, negates mechanically induced stem dwarfing of Bryonia dioica L. (Boyer et al., 1983), but aminoethoxyvinylglycine inhibits only the lateral swelling component of thigmomorphogenesis (Biro and Jaffe, 1984), suggesting that something besides $\mathrm{C}_{2} \mathrm{H}_{4}$ mediates the complex of overall plant responses. Hypobaric pressures also negate some plant responses to mechanical stress (Jaffe, 1980), presumably by removing $\mathrm{C}_{2} \mathrm{H}_{4}$ from plant tissues.

\footnotetext{
Auxin

The evidence for auxin involvement is that supraoptimal auxin mimics mechanical stress effects (Erner and Jaffe, 1982), presumably by stimulating ACC oxidase and subsequent production of $\mathrm{C}_{2} \mathrm{H}_{4}$. Thigmic stress of dark-grown pea (Pisum sativum L.) seedlings reduces elongation of subsequently cut pea stem sections floated on auxin-containing solutions, provided that sufficient minimum time
}

elapses between rubbing the plumule and cutting internode sections (Mitchell, 1977a). Because polar auxin transport is inhibited substantially by mechanical stress or $\mathrm{C}_{2} \mathrm{H}_{4}$, it is likely that endogenous auxin cannot move below the point of mechanical stress application in an unhardened pea stem. Auxin accumulates above the point of thigmic stress but depletes below that point. Irritation of stem tissue by rubbing also activates membrane-associated peroxidases that destroy natural auxin like an IAA oxidase (Hofinger et al., 1979). Depending on the point of mechanical stress application, elongating cells in the growth zone are inhibited because the growth hormone auxin is either depleted or supraoptimal within those cells.

\section{Gibberellins}

One of the most dramatic correlations between mechanical stress and phytohormones involves the gibberellins. When only the shoot tips of sunflower (Helianthus annuus L.) plants were thigmo-stressed, all extractable gibberellin (GA)-like activity disappeared from those tissues compared to undisturbed controls, which contained substantial amounts of GA activity (Beyl and Mitchell, 1983). When sunflower plants were shaken, GA-like activity disappeared mainly from flapping leaves. The tissue that is physically disturbed the most seems to undergo the greatest loss of gibberellin. Phaseolus vulgaris seedlings lost virtually all GA activity when they were mechanically perturbed (Suge, 1978). Exogenous $\mathrm{GA}_{3}$ prevented the usual stunting of rubbed bean stems (Jaffe and Biro, 1979). The combination of $\mathrm{GA}_{4+7}$ nullified the tendency for mechanically stressed cucumber (Cucumis sativus L.) plants to favor femaleness of monoecious flowers (Takahashi and Suge, 1980). The conclusion of these studies is that mechanical stress or $\mathrm{C}_{2} \mathrm{H}_{4}$ favors femaleness of cucurbit flowers, whereas GA favors maleness. Furthermore, many chemical growth retardants are GA biosynthesis inhibitors, and the effects of growth retardants often resemble effects of mechanical stress.

\section{Other phytohormones}

Reports of improved drought tolerance in beans (Moore, 1979) and prevention of drought-induced pithiness in tomato stems by mechanical stress suggest a possible role for $\mathrm{ABA}$ in mechanical stress action, similar to its known role in drought tolerance. ABA level rose 3-fold in bean stems that had been manipulated physically (Erner and Jaffe, 1982). Exogenous ABA can mimic effects of mechanical stress or $\mathrm{C}_{2} \mathrm{H}_{4}$ treatment in terms of retarded stem elongation, but unlike the other two treatments, ABA does not affect internode diameter (Jaffe, 1985). Mechanical stress increased cytokinin activity in xylem exudate from sunflower roots, but directly diminished it in leaves, suggesting that stressed plants adapt to ensure a continued supply of cytokinins for growth and development (Beyl and Mitchell, 1983).

\section{SIGNAL TRANSDUCTION MECHANISMS}

\section{Early events}

Depending on whether one is working with dark- or light-grown plants, mechanical stress begins to inhibit stem growth in seconds to minutes, respectively, following the onset of stress (Jaffe, 1973; Mitchell, 1993). In contrast, the kinetics of stress $\mathrm{C}_{2} \mathrm{H}_{4}$ production are far too slow for it to be the causal agent for initial signal transduction, but $\mathrm{C}_{2} \mathrm{H}_{4}$ does play an important role in later developmental events. However, deposition of callose ( $\beta-1,3$-polyglucan) in the cell-wall space just outside the plasma membrane occurs within seconds after the onset of stress (Jaffe, 1984b). Since this area is thought to be the site of $\mathrm{C}_{2} \mathrm{H}_{4}$ synthesis (Mattoo et al., 1982), wound callose forming there may stimulate the $\mathrm{C}_{2} \mathrm{H}_{4}$-forming enzyme complex. Another theory is that soluble, translocatable oligosaccharides arise in the wall space of rubbed plants, either as breakdown products of wall polymers or as their precursors, and that they act as "elicitors" of $\mathrm{C}_{2} \mathrm{H}_{4}$ formation and mechanical stress responses (Takahashi and Jaffe, 1982). It is not clear what role such elicitors might play in noncontact forms of mechanical stress. Calcium also regulates $\mathrm{C}_{2} \mathrm{H}_{4}$ and callose biosynthesis, as well as 
gravitropism, and plays an important role in signal transduction in general.

\section{A role for calcium}

Exogenous $\mathrm{Ca}^{2+}$, applied along with a $\mathrm{Ca}$ ionophore to the cell elongation zone of undisturbed dark-grown soybean seedlings, inhibited seedling growth in a dose-dependent fashion (Jones and Mitchell, 1989). The Ca-specific chelator ethylene glycol-bis( $\beta$ amino ethyl ether) $N, N, N^{\prime}, N^{\prime}$-tetraacetic acid (EGTA) partially negated mechanical stress-induced growth reduction, whereas the general cation chelator ethylenediaminetetraacetic acid was ineffective at all concentrations tested. Three calmodulin antagonists, chlorpromazine, 48/80, and calmidazolium, all partially negated growth inhibition similar to EGTA action. Thus, $\mathrm{Ca}$ and the $\mathrm{Ca}-$ binding regulatory protein calmodulin appear to play a part in mechanosensory transduction leading to stem growth inhibition, but they play only a partial role.

\section{Touch genes}

More evidence regarding signal transduction of mechanical stress events comes from work with the diminutive model test plant Arabidopsis thaliana L., which is readily stunted by thigmic treatments. Northern blots of electrophoretic profiles from stressed and nonstressed Arabidopsis seedlings showed that five genes were turned on by mechanical stress (Braam and Davis, 1990). Ten to $30 \mathrm{~min}$ following treatment, mRNA levels for these "touch" (TCH) genes increased up to 100 fold above control levels. However, by 2 to $3 \mathrm{~h}$ post-stress, most of these transcripts had turned over and disappeared. Three of the TCH genes are either nearly identical to genes in other species that code for calmodulin or have large regions of homology with calmodulin genes. TCH-4 codes for xyloglucan endotransglycosylase, which modifies cell wall extensibility properties (Xu et al., 1995). Increasing concentrations of external $\mathrm{Ca}$ in the growth medium of Arabidopsis cell cultures upregulates the expression of three TCH genes in those cultured cells, with kinetics of synthesis and turnover similar to a single episode of thigmic stress (Braam, 1992a). Once again, Ca appears to be important in controlling the onset of seismo- and thigmomorphogenesis.

\section{Turgor, ions, and growth changes}

Electrophysiological changes accompanying mechanical stress events are a step closer to the primary event, but still a step removed. Rubbing excised bean internodes whose cut ends were in contact with distilled water caused a rapid decrease in electrical resistance of that bathing solution compared to unrubbed controls (Jaffe, 1976b). Electrical resistance in the stem also decreased immediately after stress, and then slowly recovered. These resistance changes appear to be due to a rapid efflux of electrolytes from affected cells into vascular tissue, and then leakage from the cut ends of the stem.

Studies with a position-sensing transducer that measures plant growth in micrometers per minute of real time have revealed that a 10sec thigmic stress applied to the hypocotyl hook of dark-grown soybean seedlings caused an almost immediate (seconds) cessation of growth followed by a slow recovery phase that still was not complete after $6 \mathrm{~h}$ (Myers and Mitchell, 1993; Myers et al., 1993). As the concentration of $\mathrm{Ca}$ present in the growth medium was raised in increments from 1 to $10 \mathrm{~mm}$, the recovery phase of growth from its initial, rapid collapse was increasingly faster. For 5 or $10 \mathrm{~mm} \mathrm{Ca}^{2+}$, seedling growth rate returned to the prestress rate by $6 \mathrm{~h}$ after rubbing. The rapid, initial growth cessation with all Ca pretreatments was the same when an episode of mechanical stress was applied, suggesting that turgor collapse of cells in the elongation zone of the hypocotyl may be among the earliest cellular responses to mechanical stress. Thus, a pressure microprobe device was used to measure in situ turgor pressure of cells in the elongation zone of dark-grown soybean seedlings. A micropipette filled with silicon oil is inserted into a single cortical cell in the growth zone, and with appropriate (green) backlighting, movement of the meniscus between the oil and cell sap is observed in the capillary tip with a stereo microscope. Pressure is applied to the oil until the meniscus stops moving out of the cell, and this balancing (back) pressure measured by a transducer is taken as equal to turgor pressure. Cellular turgor increased with increasing $\mathrm{Ca}^{2+}$ in the growth medium; the higher the turgor, the higher the elongation rate of the seedling. An hour after an episode of thigmic stress, both growth rate and turgor were reduced for all treatments, but least at the highest nutritional $\mathrm{Ca}^{2+}$ level. Calcium seems to be important for turgor recovery from mechanical stress, possibly by regulating membrane permeability to water, ions, or both, but it is not present in cells at concentrations sufficient to account for the osmoticum leaking out during turgor collapse. Considering the role of $\mathrm{K}$ as an osmoticum in stomatal movements and for thigmonasty of the sensitive plant $(\mathrm{Mi}$ mosa pudica $\mathrm{L}$.), $\mathrm{K}^{+}$and $\mathrm{Ca}^{2+}$ were added to the growth medium of soybean seedlings. Peaks of oscillating growth rate during the recovery phase from stress were higher over several hours when $5 \mathrm{~mm} \mathrm{~K} \mathrm{~K}^{+}$ was added to the Ca-containing growth medium. When growth rate was monitored over $24 \mathrm{~h}$ following treatment, $\mathrm{K}^{+}$significantly enhanced the rate of growth recovery from thigmic stress. Although effects of mechanical stress on plant growth have not been completely negated by management of mineral nutrition, they can be minimized. These findings reinforce the interpretation that ions in general, and $\mathrm{Ca}$ in particular, play a central role in regulating mechanical stress responses of plants.

\section{Physical stimuli and ion gating}

The most direct evidence for rapid increases in intracellular $\mathrm{Ca}^{2+}$ concentration in response to mechanical perturbation come from studies with tobacco (Nicotiana tabacum L.) plants genetically transformed to express aequorin, a Ca-sensitive, bioluminescent protein that occurs naturally in jellyfish [Aequorea victoria (Forakalea)] (Knight et al., 1991). This luminescent protein emits blue light in the presence of $\mathrm{Ca}$ and coelenterazine, a luminophore, and can be used to measure quantitative cytosolic Ca changes in transformed plant cells. These transformed cells can be differentiated into transformed plants that give off proportional pulses of blue light whenever cytosolic $\mathrm{Ca}$ content increases by a given increment. Transformed tobacco seedlings placed within the cuvette of a luminometer gave off a pulse of blue light when exposed to puffs of air from a syringe (Knight et al., 1992). Luminous intensity was proportional to the force of air, or touch, applied to the seedlings. These results have been interpreted as an indirect, quantitative measure of the amount of Ca released suddenly into the cytoplasm in the presence of aequorin. The plasma membrane channel blocker lanthanum, and the stretch channel blocker gadolinium, failed to block the wind-induced increase in cytosolic $\mathrm{Ca}$ (hence, blue pulse detected), but they did block the same response for cold shock. However, ruthenium red, a blocker of organelle and endomembrane $\mathrm{Ca}$ channels, abolished the wind-induced cytosolic $\mathrm{Ca}$ increase but failed to block the same response for cold shock. Thus, wind-induced elevation of cytosolic Ca probably is of intracellular origin. According to current models, spectrin-like linkers connect various stretch-activated ion channels in membranes (Guharay and Sachs, 1984). Membranes become distorted when force is applied to them, and the inelastic linkers tug at their points of attachment to channel proteins. Tugging opens channels briefly and allows specific ions, like $\mathrm{Ca}^{2+}$, to flow from mitochondria, endoplasmic reticulum, or other internal membranes into the cytoplasm, where they activate calmodulin. However, since initial perception of mechanical stress occurs first outside the cell, that force must be transmitted through the extracellular matrix, across the plasma membrane, and signaled along to stretch-activated $\mathrm{Ca}^{2+}$ channels within the cytoskeleton. Proteins called "integrins" are physically connected to cell wall proteins on the outside of the plasma membrane and have domains extending into the cytosol where they can bind to actin-like filaments and other elements of the cytoskeleton to transmit physical stimuli outside the cell to stretch channels inside (Fleurat-Lessard et al., 1988). Thus, the plant cell is emerging as a highly integrated structure for mechanoperception and transduction of physical signals into biophysical responses involving ion compartmentalization, water status, and subsequent molecular and physiological changes. 


\section{Literature Cited}

Akers, S. and C. Mitchell. 1980. Stimulation of plant growth by mechanical vibration. HortScience (suppl.) 14:6.

Akers, S. and C. Mitchell. 1984. Seismic stress effects on vegetative and reproductive development of 'Alaska' pea. Can. J. Bot. 62:2011-2015.

Akers, S. and C. Mitchell. 1985. Seismic stress effects on reproductive structures of tomato, potato, and marigold. HortScience 20:684-686.

Ball, N. 1926. Transmission of stimuli in plants. Nature (London) 118:589590.

Beyl, C. and C. Mitchell. 1977a. Automated mechanical stress application for height control of greenhouse chrysanthemum. HortScience 12:575-577.

Beyl, C. and C. Mitchell. 1977b. Characterization of mechanical stress dwarfing in chrysanthemum. J. Amer. Soc. Hort. Sci. 102:591-594.

Beyl, C. and C. Mitchell. 1983. Alteration of growth, exudation rate, and endogenous hormone profiles in mechanically dwarfed sunflower. J. Amer. Soc. Hort. Sci. 108:257-262.

Biro, R. and M. Jaffe. 1984. Thigmomorphogenesis: Ethylene evolution and its role in the changes observed in mechanically perturbed bean plants. Physiol. Plant. 62:289-296.

Boyer, N., M.-O. Desbiez, M. Hofinger, and T. Gaspar. 1983. Effect of lithium on thigmomorphogenesis in Bryonia dioica ethylene production and sensitivity. Plant Physiol. 72:522-525.

Boyer, N., G. Jaegher, M.-C. Bon, and T. Gaspar. 1986. Cobalt inhibition of thigmomorphogenesis in: Possible role and mechanism of ethylene production. Physiol. Plant. 67:552-556.

Braam, J. 1992a. Regulated expression of the calmodulin-related TCH genes in cultured Arabidopsis cells: Induction by calcium and heat shock. Proc. Natl. Acad. Sci. USA 89:3213-3216.

Braam, J. and R. Davis. 1990. Rain-, wind-, and touch-induced expression of calmodulin and calmodulin-related genes in Arabidopsis. Cell 60:357364.

Erner, Y., R. Biro, and M. Jaffe. 1980. Thigmomorphogenesis: Evidence for a translocatable thigmomorphogenetic factor induced by mechanical perturbation of beans. Physiol. Plant. 50:21-25.

Erner, Y. and M. Jaffe. 1982. Thigmomorphogenesis: The involvement of auxin and abscisic acid in growth retardation due to mechanical perturbation. Plant Cell Physiol. 23:935-941.

Fleurat-Lessard, P., G. Roblin, J. Bonmort, and C. Besse. 1988. Effects of colchicine, vinblastine, cytochalasin B and phalloidin on the seismonastic movement of Mimosa pudica leaf and on motor cell ultrastructure. J. Expt. Bot. 39:209-221.

Goeschl, J., L. Rappaport, and H. Pratt. 1966. Ethylene as a factor regulating the growth of pea epicotyls subjected to physical stress. Plant Physiol. $41: 877-884$.

Guharay, F. and F. Sachs. 1984. Stretch-activated single ion channel currents in tissue cultured embryonic chick skeletal muscle. J. Physiol. 352:685701.

Hammer, P., C. Mitchell, and T. Weiler. 1974. Height control in greenhouse chrysanthemum by mechanical stress. HortScience 9:474-475.

Heuchert, J., J. Marks, and C. Mitchell. 1983. Strengthening of tomato shoots by gyratory shaking. J. Amer. Soc. Hort. Sci. 108:801-805.

Heuchert, J. and C. Mitchell. 1983. Inhibition of shoot growth in greenhousegrown tomato by periodic gyratory shaking. J. Amer. Soc. Hort. Sci. 108:795-800

Hofinger, M., B. Chapelle, N. Boyer, and T. Gaspar. 1979. GC-MS identification and titration of IAA in mechanically perturbed Bryonia dioica. Plant Physiol. 63:S52.

Jaffe, M. 1973. Thigmomorphogenesis: The response of plant growth and development to mechanical stimulation. Planta 114:143-157.

Jaffe, M. 1976a. Thigmomorphogenesis: A detailed characterization of the response of beans to mechanical stimulation. Z. Pflanzenphysiol. 77S:437453.

Jaffe, M. 1976b. Thigmomorphogenesis: Electrical resistance and mechanical correlates of the early events of growth retardation due to mechanical stimulation in beans. Z. Pflanzenphysiol. 78S:24-32.

Jaffe, M. 1980. Morphogenetic responses of plants to mechanical stimuli or stress. BioScience 30:239-243.

Jaffe, M. 1984b. The involvement of callose and elicitors in ethylene production caused by mechanical perturbation, p. 199-215. In: Y. Fuchs and E. Chalutz (eds.). Ethylene: Biochemical, physiological and applied aspects. Nijhoff/Junk, The Hague, The Netherlands.

Jaffe, M. 1985. Wind and other mechanical effects in the development and behavior of plants, with special emphasis on the role of humans, p. 444 484. In: R. Pharis and D. Reid (eds.). Encyclopedia of plant physiology. vol. 11. Hormonal regulation of development III. Springer-Verlag, New York.

Jaffe, M. and R. Biro. 1979. Thigmomorphogenesis: The effect of mechanical perturbation on the growth of plants, with special reference to anatomical changes, the role of ethylene, and interaction with other environmental stresses, p. 25-59. In: H. Mussell and R. Staples (eds.). Stress physiology in crop plants. Wiley, New York.

Jones, R., L. Coe, L. Montgomery, and C. Mitchell. 1990. Seismic stress responses of soybean to different photosynthetic photon flux. Ann. Bot. 66:617-622.

Jones, R. and C. Mitchell. 1989. Calcium ion involvement in growth inhibition of mechanically stressed soybean seedlings. Physiol. Plant. 76:598-602.

Klickoff, L. 1965. Microenvironmental influences on vegetational pattern near timberline in the central Sierra Nevada. Ecol. Monogr. 35:187-211.

Knight, M., A. Campbell, S. Smith, and A. Trewavas. 1991. Transgenic plant aequorin reports the effects of touch and cold-shock and elicitors on cytoplasmic calcium. Nature (London) 352:524-526.

Knight, M., S. Smith, and A. Trewavas. 1992. Wind-induced plant motion immediately increases cytosolic calcium. Proc. Natl. Acad. Sci. USA 89:4967-4971

Latimer, J. 1991a. Brushing can control transplant height. Amer. Veg. Grower 39(4):98, 102-103.

Latimer, J. 1991b. Mechanical conditioning for control of growth and quality of vegetable transplants. HortScience 26:1456-1461.

Latimer, J. and R. Beverly. 1993. Mechanical conditioning of greenhousegrown transplants. HortTechnology 3:412-414.

Latimer, J., T. Johjima, and K. Harada. 1991. The effect of mechanical stress on growth and subsequent yield of four cultivars of cucumber. Scientia Hort. 47:221-230.

Mattoo, A., D. Achilea, Y. Fuchs, and E. Chalutz. 1982. Membrane association and some characteristics of the ethylene forming enzyme from etiolated pea seedlings. Biochem. Biophys. Res. Communications 105:271-278.

Mitchell, C. 1977a. Influence of mechanical stress on auxin-stimulated growth of excised pea stem sections. Physiol. Plant. 41:129-134.

Mitchell, C. 1977b. NASA launches a new experiment to explore how plants react to stress. Horticulture Sept.:10-13.

Mitchell, C. 1992. Modification of plant growth and development by acceleration and vibration: Concerns and opportunities for plant experimentation in orbiting spacecraft. Adv. Space Res. 12:219-225.

Mitchell, C. 1993. Mechanical stress regulation of plant growth and development, p. 79-81. In: T. Halstead (ed.). 1990-91 NASA space biology accomplishments. NASA Tech. Memorandum 4501.

Mitchell, C., C. Severson, J. Wott, and P. Hammer. 1975. Seismomorphogenic regulation of plant growth. J. Amer. Soc. Hort. Sci. 100:161-165.

Moore, T. 1979. Biochemistry and physiology of plant hormones. SpringerVerlag, New York.

Myers, P., J. Ackerman, and C. Mitchell. 1993. Growth and turgor responses of dark-grown soybean seedlings to mechanical perturbation. Plant Physiol. 102(suppl.): 156

Myers, P. and C. Mitchell. 1993. Growth and turgor of dark-grown soybean seedlings following mechanical stress. Bul. Amer. Soc. Gravitational Space Biol. 7:94

Pappas, T. and C. Mitchell. 1985a. Effects of seismic stress on the vegetative growth of Glycine $\max$ (L.) Merr. cv. Wells II. Plant, Cell Environ. 8:143148.

Pappas, T. and C. Mitchell. 1985b. Influence of seismic stress on photosynthetic productivity, gas exchange, and leaf diffusive resistance of Glycine $\max$ (L.) Merrill cv. Wells II. Plant Physiol. 79:285-289.

Suge, H. 1978. Growth and gibberellin production in Phaseolus vulgaris as affected by mechanical stress. Plant Cell Physiol. 19:1557-1560.

Takahashi, H. and M. Jaffe. 1982. The interaction of callose and ethylene in thigmomorphogenesis. Physiologist 25:S-139-S-140.

Takahashi, H. and Suge. 1980. Sex expression in cucumber plants as affected by mechanical stress. Plant Cell Physiol. 21:303-310.

Takahashi, H., H. Suge, and T. Kato. 1991. Growth promotion by vibration at $50 \mathrm{~Hz}$ in rice and cucumber seedlings. Plant Cell Physiol. 32:729-732.

Toriyama, H. 1955. Observational and experimental studies of sensitive plants. The migration of potassium in the primary pulvinus. Cytologia 20:367377.

Xu, W., M. Purugganan, D. Polisensky, D. Antosiewicz, S. Fry, and J. Braam. 1995. Arabidopsis TCH4, regulated by hormones and the environment, encodes a xyloglucan endotransglycosylase. Plant Cell 7:1555-1567. 


\title{
Regulation of Plant Growth Responses to Low Soil Water Potentials
}

\author{
Robert E. Sharp \\ Plant Science Unit, 1-87 Agriculture Building, University of Missouri, Columbia, MO 65211
}

When soil water availability is limited, plant growth is usually decreased. Most research interest in the physiology of growth responses to soil drying has focused on the inhibition of shoot growth. While this used to be considered the direct result of turgor loss in expanding cells, in the past decade, studies have shown that stem and leaf growth may be inhibited at low water potentials $\left(\psi_{\mathrm{w}}\right)$ despite complete maintenance of turgor in the growing regions as a result of osmotic adjustment (Michelena and Boyer, 1982; Nonami and Boyer, 1989). This relationship suggested that the growth inhibition may be metabolically regulated, possibly serving an adaptive role by restricting the development of transpiring surface area. Indeed, leaf growth is often so sensitive to soil drying that substantial inhibition can occur before the development of decreased $\psi_{\mathrm{w}}$ in the aerial plant parts, leading to much recent interest in the involvement of nonhydraulic signals from the roots (Davies and Zhang, 1991; Munns and Sharp, 1993). This topic is briefly addressed at the end of this paper.

In contrast, little attention has been given to the physiology of the growth responses of the roots themselves, although it has long been recognized that root growth may be less inhibited than shoot growth, or even promoted, under conditions of soil drying (Jupp and Newman, 1987; Sharp and Davies, 1979; Weaver, 1926). This behavior is considered an important factor in determining plant performance when the water supply is limited (Sharp and Davies, 1989). Perhaps, the best example comes from a field study of common bean (Phaseolus vulgaris L.) by Sponchiado et al. (1989). Four lines were examined that, under irrigated conditions, were similar in root system development and final yield. Under dryland conditions, however, two lines exhibited a pronounced increase in root proliferation and yielded three times as much as the lines lacking this response. Subsequent grafting studies, using the same lines, showed that the capacity for root proliferation in drying soil, and the associated yield advantage, were determined by the rootstock (White and Castillo, 1989), which indicates the involvement of some form of internal regulation within the roots.

An important aspect of the root system response to soil drying is the ability of some roots to continue elongation at $\psi_{\mathrm{w}}$ that are low enough to completely inhibit shoot growth. This feature is evident in nodal (adventitious) roots of maize (Zea mays L.), which penetrate through the often dry surface soil (Westgate and Boyer, 1985), and for the primary root in seedlings of several species (Sharp et al., 1988; Spollen et al., 1993). The primary root of maize maintains substantial elongation rates at $\psi_{\mathrm{w}}$ as low as $-1.6 \mathrm{MPa}$, whereas shoot elongation is much more sensitive to decreases in $\psi_{\mathrm{w}}$ and is completely inhibited at about $-0.8 \mathrm{MPa}$ (Fig. 1). This differential response helps to ensure a supply of water before shoot emergence, which is clearly advantageous for seedling establishment under dry conditions.

While many readers might readily accept that hormones are likely to be important in determining plant growth responses to environmental variation, there is surprisingly little definitive evidence for the role of any hormone in regulating either shoot or root growth under conditions of soil drying. Interest in this question has focused on abscisic acid (ABA), and this paper reviews recent evidence that $\mathrm{ABA}$ plays important roles in shoot growth inhibition and root growth maintenance at low soil $\psi_{\mathrm{w}}$.

Received for publication 25 May 1995. Accepted for publication 24 July 1995. Supported by National Science Foundation grant IBN 9306935 to R.E.S. and Eric S. Ober, and the Food for the 21st Century Program, Univ. of Missouri, Columbia. Contribution from the Missouri Agricultural Experiment Station, Journal Series no. 12,253. The cost of publishing this paper was defrayed in part by the payment of page charges. Under postal regulations, this paper therefore must be hereby marked advertisement solely to indicate this fact.

\section{ROLE OF ABA}

ABA is well-known to accumulate to high concentrations in plant tissues under water-limited conditions. In addition to its established role in regulating stomatal behavior (MacRobbie, 1991), there has been considerable speculation that $\mathrm{ABA}$ is involved in the growth responses of water-stressed plants, mostly concerning a role in growth inhibition. This view has arisen because, in the majority of studies, applications of ABA to well-watered plants have resulted in inhibition of shoot and root growth (Quarrie and Jones, 1977; Robertson et al., 1990), although, in both cases, there also are a few reports of growth promotion (Munns and Sharp, 1994; Pilet and Saugy, 1987; Takahashi, 1972). In most such studies, measurements were not made to determine whether the resulting internal levels of ABA were similar to those that occur at low $\psi_{\mathrm{w}}$. Furthermore, even if realistic internal levels are achieved by applying ABA to plants at high $\psi_{\mathrm{w}}$ (Creelman et al., 1990), the effects may differ from those at low $\psi_{\mathrm{w}}$, because changes in ABA sensitivity (Tardieu and Davies, 1992), response (Rodriguez and Davies, 1982), and compartmentation (Hartung et al., 1988) with variation in environmental conditions have been reported for various tissues.

To avoid such difficulties in interpretation, the role of ABA in the differential sensitivities of root and shoot elongation to water stress in maize seedlings was investigated recently by inhibiting endogenous ABA accumulation at low $\psi_{\mathrm{w}}$ (Saab et al., 1990, 1992; Sharp et al., 1994). Two methods were used: first, the inhibitor fluridone, which blocks carotenoid (and ABA) synthesis, and second, the $v p 5$ mutant,

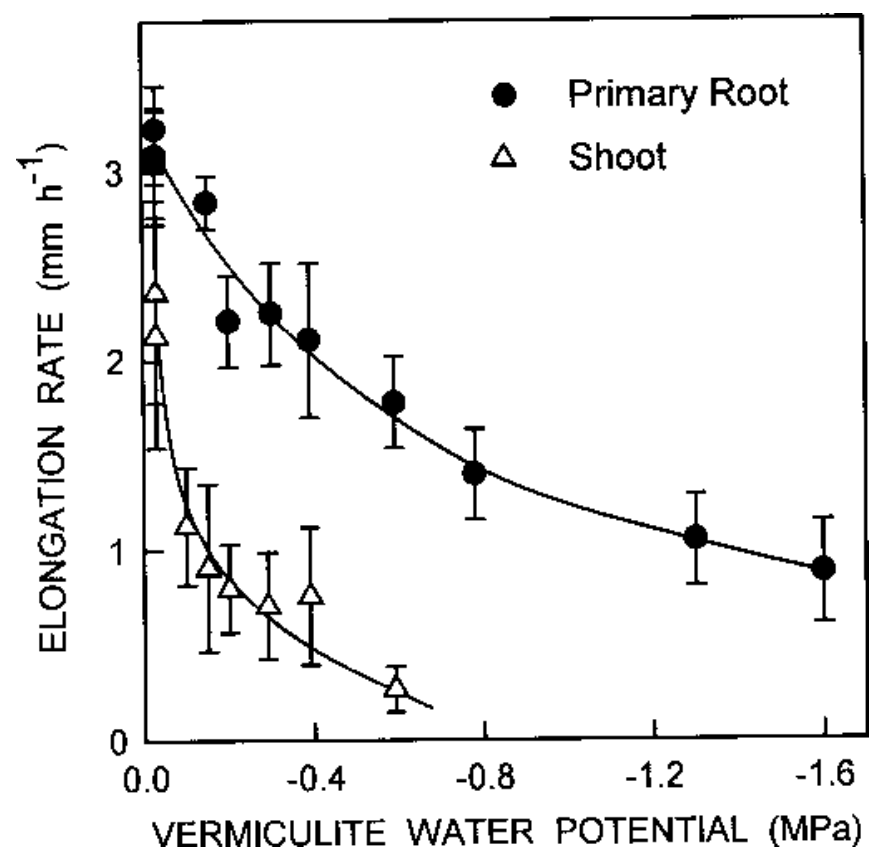

Fig. 1. Elongation rate of the primary root and shoot of maize seedlings in vermiculite of various water potentials. Seeds were germinated for $36 \mathrm{~h}$ in well-watered vermiculite, then seedlings were transplanted to vermiculite at different water potentials (obtained by mixing with various amounts of $10^{-4} \mathrm{M} \mathrm{CaCl}_{2}$ ) and grown in darkness at $29 \mathrm{C}$ and near-saturation humidity. For roots, data were obtained at root lengths of $5 \mathrm{~cm}$, when elongation rates were approximately steady. For shoots, data represent the maximum elongation rates obtained after transplanting. Bars are \pm 1 SD $(n=10-40)$ (from Sharp, 1990). 
which carries a lesion at the same step as that blocked by fluridone. Indirect effects of altered ABA levels on growth due to changes in stomatal control of photosynthesis or plant water balance were precluded by conducting the experiments in darkness at near-saturation humidity.

The results obtained with the two methods were very similar. At high $\psi_{\mathrm{w}}$, root and shoot elongation rates (and ABA contents) were affected little. However, when ABA accumulation was decreased in seedlings transplanted to vermiculite at a $\psi_{\mathrm{w}}$ of $-1.6 \mathrm{MPa}$, primary root elongation was severely inhibited (Saab et al., 1990, 1992); this effect

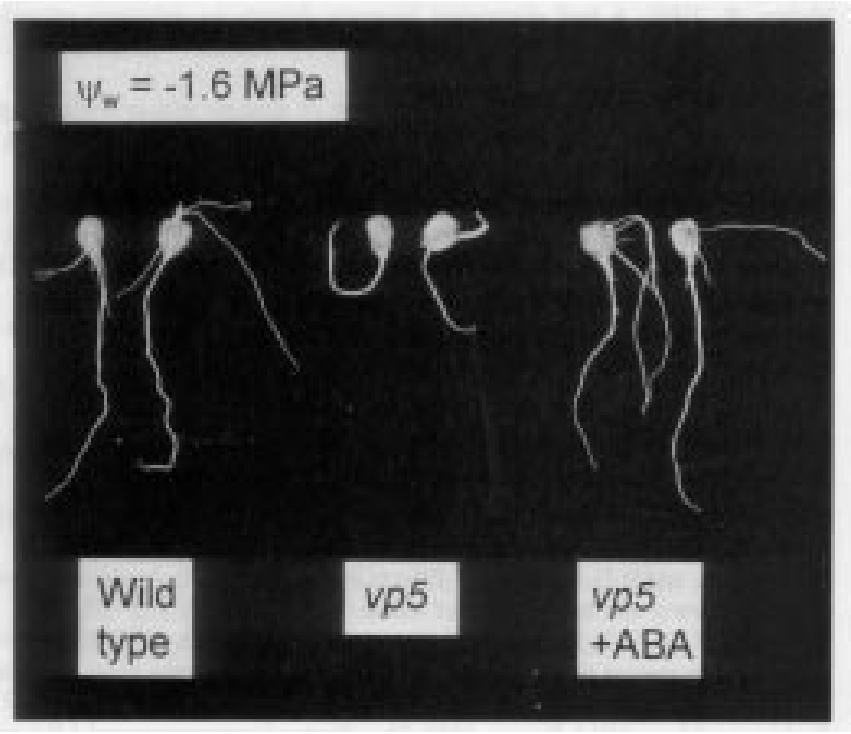

Fig. 2. Representative wild-type and $v p 5$ maize seedlings, the latter with or without the addition of ABA $(0.7 \mathrm{~mm})$ to the vermiculite, $100 \mathrm{~h}$ after transplanting to a $\psi_{\mathrm{w}}$ of $-1.6 \mathrm{MPa}$. Contents of ABA in the apical $10 \mathrm{~mm}$ of the primary root (encompassing the elongation zone) were ( $\mathrm{ng} / \mathrm{g} \mathrm{H}_{2} \mathrm{O} \pm$ $\mathrm{SE}, \mathrm{n}=3-6)$ : wild-type, $118 \pm 18 ; v p 5,21 \pm 5$; vp5 + ABA, $96 \pm 29$. The requirement for such a high applied $\mathrm{ABA}$ concentration to restore the internal ABA content was due to limited uptake from the dry vermiculite (from Sharp et al., 1994)

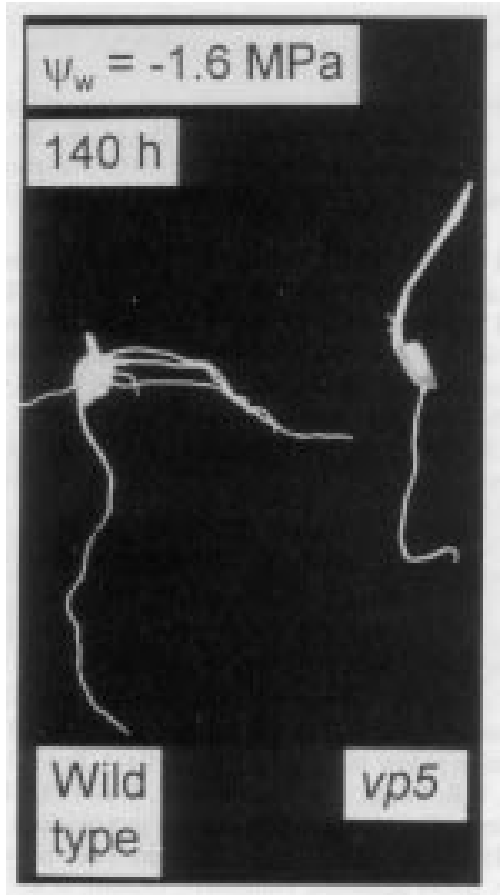

Fig. 3. Representative wild-type and $v p 5$ maize seedlings $140 \mathrm{~h}$ after transplanting to vermiculite at a $\psi_{\mathrm{w}}$ of $-1.6 \mathrm{MPa}$. Whole-shoot ABA contents (ng/g $\mathrm{H}_{2} \mathrm{O} \pm \mathrm{se}, \mathrm{n}=2-3$ ) were: wild-type, $93 \pm 17 ; v p 5,16 \pm 4$ (from Sharp et al., 1994). is illustrated for $v p 5$ seedlings (Fig. 2). Root elongation recovered when the ABA level in the root growth zone was restored (by mixing ABA with the vermiculite; Fig. 2), showing that ABA accumulation is required to maintain maize primary root elongation at low $\psi_{\mathrm{w}}$ (Sharp et al., 1994). The effects of ABA status on root growth were independent of effects on the shoot, since shoot growth was almost completely inhibited in all treatments for the 100-h duration of the experiments (Fig. 2). When the duration was extended, however, the $v p 5$ seedling shoots began to elongate at substantial rates, whereas the wild-type shoots remained inhibited (Fig. 3). Thus, ABA deficiency allowed shoot elongation at a $\psi_{w}$ twice as low as that which is normally completely inhibitory (Fig. 1). Shoot elongation also was promoted in ABA-deficient seedlings (using either fluridone or the $v p 5$ mutant) when similar experiments were conducted at a higher $\psi_{\mathrm{w}},-0.3 \mathrm{MPa}$ (Saab et al., 1990, 1992; Sharp et al., 1994). These results indicate that the accumulation of $\mathrm{ABA}$ also accounts for at least part of the inhibition of shoot growth in maize seedlings at low $\psi_{\mathrm{w}}$.

Importantly, the role of ABA accumulation in the maintenance of maize primary root elongation at low $\psi_{\mathrm{w}}$ could not have been inferred from experiments with well-watered plants. Root elongation in seedlings growing at high $\psi_{\mathrm{w}}$ was substantially inhibited when the ABA content of the elongation zone was raised to the level found at -1.6 MPa (Table 1; see Fig. 2 caption). Thus, the response of root elongation to bulk tissue ABA content varied with water status. This finding is in accordance with Trewavas' $(1986,1987)$ proposals that changes in hormone sensitivity are likely to be an integral component of developmental responses to environmental variation.

\section{Mechanism of ABA action}

Recent evidence indicates that the inhibition of elongation in ABAdeficient roots at low $\psi_{\mathrm{w}}$ involves the action of ethylene. Sharp et al. (1993) observed that the primary roots of fluridone-treated and $v p 5$ maize seedlings at low $\psi_{\mathrm{w}}$ not only are shorter but also show a pronounced radial swelling that starts at $\approx 1 \mathrm{~mm}$ from the tip. This response is similar to the known effect of exogenous ethylene on maize roots (Whalen and Feldman, 1988). To test for the involvement of ethylene, several inhibitors of ethylene synthesis or binding were applied to fluridone-treated roots at a $\psi_{\mathrm{w}}$ of $-1.6 \mathrm{MPa}$ to see whether elongation could be restored while ABA levels remained low. Root elongation recovered (and radial swelling decreased) with each inhibitor tested-in some cases to almost the rate obtained in nontreated roots (W.G. Spollen, M.E. LeNoble, and R.E.S., unpublished data). Experiments are in progress to determine whether ABA accumulation restricts ethylene synthesis, root sensitivity to ethylene, or both. Preliminary results show that ethylene evolution is greatly enhanced in fluridone-treated seedlings at low $\psi_{\mathrm{w}}$, and that this is prevented by adding $\mathrm{ABA}$ at the concentration shown previously to restore root elongation.

The experiments described above did not reveal whether the action of $\mathrm{ABA}$ in shoot growth inhibition at low $\psi_{\mathrm{w}}$ also involves an interaction with ethylene, since shoot growth was completely inhibited in all treatments. This possibility is under investigation.

Table 1. Effect of applied ABA on tip ABA content and length of maize primary roots at high water potential. ${ }^{z}$

\begin{tabular}{lcc}
\hline $\begin{array}{l}\text { Applied } \\
\text { ABA concn } \\
(\mu \mathrm{M})\end{array}$ & $\begin{array}{c}\text { Tip ABA } \\
\text { content } \\
\left(\mathrm{ng} / \mathrm{g} \mathrm{H}_{2} \mathrm{O}\right)\end{array}$ & $\begin{array}{c}\text { Primary root } \\
\text { length } \\
(\mathrm{mm})\end{array}$ \\
\hline 0 & $15 \pm 3$ & $210 \pm 3$ \\
1 & $34 \pm 9$ & $195 \pm 3$ \\
2 & $44 \pm 5$ & $175 \pm 4$ \\
5 & $70 \pm 6$ & $163 \pm 3$ \\
10 & $101 \pm 7$ & $147 \pm 4$ \\
\hline
\end{tabular}

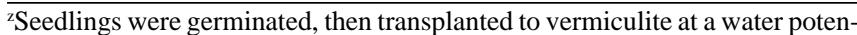
tial of $-0.03 \mathrm{MPa}$, which was mixed with various concentrations of ABA. The plants were grown for $76 \mathrm{~h}$. ABA contents are for the apical $10 \mathrm{~mm}$, which encompassed the elongation zone. Data are means $\pm \mathrm{SE}$ (ABA contents, $\mathrm{n}=8-$ 9 ; lengths, $n=48-54$; results were combined from three experiments). From Sharp et al. (1994). 
ABA accumulation in maize primary roots at low $\psi_{w}$ also is required for two other responses that are thought to contribute to growth maintenance: 1) for a dramatic increase in proline concentration in the root tip, which makes a major contribution to turgor maintenance by osmotic adjustment (Ober and Sharp, 1994; Voetberg and Sharp, 1991), and 2) for an increase in activity of the enzyme xyloglucan endotransglycosylase (XET), which is thought to contribute to enhanced cell-wall loosening (Wu et al., 1994). In both cases, the responses were inhibited in $\mathrm{ABA}$-deficient roots and could be restored with exogenous ABA.

\section{ABA AS A ROOT SIGNAL}

As mentioned in the introduction, under conditions of soil drying, leaf growth can be substantially inhibited without a change in leaf water status and, in some cases, before decreases in stomatal conductance (Passioura, 1988; Saab and Sharp, 1989). These observations suggested that some kind of nonhydraulic, growth-regulatory signal communicates the dry soil condition to the leaves. In a study of apple (Malus domestica Borkh.) trees with their root systems divided between wet and dry soil compartments, Gowing et al. (1990) showed that leaf growth recovered when the roots in dry soil were excised, indicating that the roots were producing an inhibitor of leaf growth rather than decreased amounts of a growth promoter. An obvious candidate is ABA, but the studies that have addressed this possibility have produced conflicting results. In maize, Zhang and Davies (1990a, 1990b) reported that the increase in xylem sap ABA concentration during soil drying could account for the accompanying inhibition of leaf growth, since a similar relationship between xylem ABA and leaf growth was obtained when ABA was fed to the roots of well-watered plants. However, in wheat (Triticum aestivum L.) plants with leaf growth inhibited by soil drying, Munns (1992) found that the xylem sap ABA concentration, although increased, was an order of magnitude lower than that required to inhibit the growth of leaves from wellwatered plants in a bioassay, and concluded that ABA was not the root signal. Importantly, the interpretations of both studies depend on the sensitivity of leaf growth to ABA being the same in the ABA-fed, wellwatered leaves and in the leaves of plants subjected to soil drying. However, the studies with maize seedlings described above show that, for root growth, a given level of ABA has different effects in wellwatered and water-stressed plants; this difference might also apply to leaf growth, at least in some species. This possibility has not yet been addressed. For this and other reasons (discussed in detail in Munns and Sharp, 1993), the role of ABA as a root signal that inhibits leaf growth during soil drying remains uncertain.

\section{CONCLUSION}

Experiments with an ABA-deficient mutant and an inhibitor of ABA synthesis have shown that endogenous $\mathrm{ABA}$ accumulation plays an important role in the maintenance of primary root growth and in the inhibition of shoot growth in maize seedlings at low $\psi_{\mathrm{w}}$. ABA also may act as a root signal that inhibits leaf growth during soil drying in the absence of leaf water deficits. Little is known about the involvement of other hormones in these responses, although recent evidence indicates an interaction of $\mathrm{ABA}$ with ethylene in the regulation of root growth. Caution should be applied when interpreting the effects of hormones applied to well-watered plants because hormonal sensitivity or response of tissues can vary with water status.

\section{Literature Cited}

Creelman, R.A., H.S. Mason, R.J. Bensen, J.S. Boyer, and J.E. Mullet. 1990. Water deficit and abscisic acid cause differential inhibition of shoot versus root growth in soybean seedlings. Analysis of growth, sugar accumulation, and gene expression. Plant Physiol. 92:205-214.

Davies, W.J. and J. Zhang. 1991. Root signals and the regulation of growth and development of plants in drying soil. Annu. Rev. Plant Physiol. Plant Mol. Biol. 42:55-76.

Gowing, D.J.G., W.J. Davies, and H.G. Jones. 1990. A positive root-sourced signal as an indicator of soil drying in apple, Malus $\times$ domestica Borkh. J. Expt. Bot. 41:1535-1540.
Hartung, W., J.W. Radin, and D.L. Hendrix. 1988. Abscisic acid movement into the apoplastic solution of water-stressed cotton leaves. Role of apoplastic pH. Plant Physiol. 86:908-913.

Jupp, A.P. and E.I. Newman. 1987. Morphological and anatomical effects of severe drought on the roots of Lolium perenne L. New Phytol. 105:393402 .

MacRobbie, E.A.C. 1991. Effect of ABA on ion transport and stomatal regulation, p. 153-168. In: W.J. Davies and H.G. Jones (eds.). Abscisic acid. BIOS Scientific Publishers, Oxford, U.K.

Michelena, V.A. and J.S. Boyer. 1982. Complete turgor maintenance at low water potentials in the elongation region of maize leaves. Plant Physiol. 69:1145-1149.

Munns, R. 1992. A leaf elongation bioassay detects an unknown growth inhibitor in xylem sap from wheat and barley. Austral. J. Plant Physiol. 19:127-135.

Munns, R. and R.E. Sharp. 1993. Involvement of abscisic acid in controlling plant growth in soils of low water potential. Austral. J. Plant Physiol. 20:425-437.

Munns, R. and R.E. Sharp. 1994. Regulation of shoot growth in dry soils by abscisic acid and by root messages, p. 303-313. In: J.H. Cherry (ed.). Biochemical and cellular mechanisms of stress tolerance in plants. NATO ASI Ser. vol. H 86. Springer-Verlag, Berlin.

Nonami, H. and J.S. Boyer. 1989. Turgor and growth at low water potentials. Plant Physiol. 89:798-804.

Ober, E.S. and R.E. Sharp. 1994. Proline accumulation in maize (Zea mays L.) primary roots at low water potentials. Plant Physiol. 105:981-987.

Passioura, J.B. 1988. Root signals control leaf expansion in wheat seedlings growing in drying soil. Austral. J. Plant Physiol. 15:687-693.

Pilet, P.E. and M. Saugy. 1987. Effects on root growth of endogenous and applied IAA and ABA. A critical examination. Plant Physiol. 83:33-38.

Quarrie, S.A. and H.G. Jones. 1977. Effects of abscisic acid and water stress on development and morphology of wheat. J. Expt. Bot. 28:192-203.

Robertson, J.M., K.T. Hubick, E.C. Yeung, and D.M. Reid. 1990. Developmental responses to drought and abscisic acid in sunflower roots. I. Root growth, apical anatomy, and osmotic adjustment. J. Expt. Bot. 41:325-337.

Rodriguez, J.L. and W.J. Davies. 1982. The effects of temperature and ABA on stomata of Zea mays L. J. Expt. Bot. 33:977-987.

Saab, I.N. and R.E. Sharp. 1989. Non-hydraulic signals from maize roots in drying soil: Inhibition of leaf elongation but not stomatal conductance. Planta 179:466-474.

Saab, I.N., R.E. Sharp, and J. Pritchard. 1992. Effect of inhibition of abscisic acid accumulation on the spatial distribution of elongation in the primary root and mesocotyl of maize at low water potentials. Plant Physiol. 99:2633.

Saab, I.N., R.E. Sharp, J. Pritchard, and G.S. Voetberg. 1990. Increased endogenous abscisic acid maintains primary root growth and inhibits shoot growth of maize seedlings at low water potentials. Plant Physiol. 93:13291336.

Sharp, R.E. 1990. Comparative sensitivity of root and shoot growth and physiology to low water potentials, p. 29-44. In: W.J. Davies and B. Jeffcoat (eds.). Importance of root to shoot communication in the responses to environmental stress. Monogr. 21. British Soc. Plant Growth Regulat., Bristol.

Sharp, R.E. and W.J. Davies. 1979. Solute regulation and growth by roots and shoots of water-stressed maize plants. Planta 147:43-49.

Sharp, R.E. and W.J. Davies. 1989. Regulation of growth and development of plants growing with a restricted supply of water, p. 72-93. In: H.G. Jones, T.J. Flowers, and M.B. Jones (eds.). Plants under stress. Cambridge Univ. Press, Cambridge, U.K.

Sharp, R.E., W.K. Silk, and T.C. Hsiao. 1988. Growth of the maize primary root at low water potentials. I. Spatial distribution of expansive growth. Plant Physiol. 87:50-57.

Sharp, R.E., G.S. Voetberg, I.N. Saab, and N. Bernstein. 1993. Role of abscisic acid in the regulation of cell expansion in roots at low water potentials, $p$. 57-66. In: T.J. Close and E.A. Bray (eds.). Plant responses to cellular dehydration during environmental stress. Amer. Soc. Plant Physiol., Rockville, Md.

Sharp, R.E., Y. Wu, G.S. Voetberg, I.N. Saab, and M.E. LeNoble. 1994. Confirmation that abscisic acid accumulation is required for maize primary root elongation at low water potentials. J. Expt. Bot. 45:1743-1751.

Spollen, W.G., R.E. Sharp, I.N. Saab, and Y. Wu. 1993. Regulation of cell expansion in roots and shoots at low water potentials, p. 37-52. In: J.A.C. Smith and H. Griffiths (eds.). Water deficits. Plant responses from cell to community. BIOS Scientific Publishers, Oxford, U.K.

Sponchiado, B.N., J.W. White, J.A. Castillo, and P.G. Jones. 1989. Root growth of four common bean cultivars in relation to drought tolerance in environments with contrasting soil types. Expt. Agr. 25:249-257.

Takahashi, K. 1972. Abscisic acid as a stimulator for rice mesocotyl growth. Nature New Biol. 238:92-93. 
Tardieu, F. and W.J. Davies. 1992. Stomatal response to ABA is a function of current plant water status. Plant Physiol. 98:540-545.

Trewavas, A.J. 1986. Resource allocation under poor growth conditions. A major role for growth substances in developmental plasticity, p. 31-76. In: D.H. Jennings and A.J. Trewavas (eds.). Plasticity in plants. Company of Biologists, Cambridge, U.K.

Trewavas, A.J. 1987. Sensitivity and sensory adaptation in growth substance responses, p. 19-38. In: G.V. Hoad, J.R. Lenton, M.B. Jackson, and R.K. Atkin (eds.). Hormone action in plant development-A critical appraisal. Butterworths, London.

Voetberg, G.S. and R.E. Sharp. 1991. Growth of the maize primary root at low water potentials. III. Role of increased proline deposition in osmotic adjustment. Plant Physiol. 96:1125-1130.

Weaver, J.E. 1926. Root development of field crops. McGraw-Hill, New York.

Westgate, M.E. and J.S. Boyer. 1985. Osmotic adjustment and the inhibition of leaf, root, stem and silk growth at low water potentials in maize. Planta 164:540-549.

Whalen, M.C. and L.J. Feldman. 1988. The effect of ethylene on root growth of Zea mays seedlings. Can. J. Bot. 66:719-723.

White, J.W. and J.A. Castillo. 1989. Relative effect of root and shoot genotypes on yield of common bean under drought stress. Crop Sci. 29:360-362.

Wu, Y., W.G. Spollen, R.E. Sharp, P.R. Hetherington, and S.C. Fry. 1994. Root growth maintenance at low water potentials. Increased activity of xyloglucan endotransgylcosylase and its possible regulation by abscisic acid. Plant Physiol. 106:607-615.

Zhang, J. and W.J. Davies. 1990a. Changes in the concentration of ABA in xylem sap as a function of changing soil water status can account for changes in leaf conductance and growth. Plant Cell Environ. 13:277-285.

Zhang, J. and W.J. Davies. 1990b. Does ABA in the xylem control the rate of leaf growth in soil-dried maize and sunflower plants? J. Expt. Bot. 41:1125-1132.

\title{
Low-temperature Stress Tolerance: The Role of Abscisic Acid, Sugars, and Heat-stable Proteins
}

\author{
L.V. Gusta \\ Crop Development Centre, University of Saskatchewan, Saskatoon, Saskatchewan S7N 5A8, Canada \\ R.W. Wilen \\ Department of Biochemistry, University of Saskatchewan, Saskatoon, Saskatchewan S7N 5E5, Canada \\ P. Fu \\ Crop Science Department, University of Saskatchewan, Saskatoon, Saskatchewan S7N 5A8, Canada
}

There are about 300,000 species of plants in the world, 250,000 of which are angiosperms. Low temperatures, at extreme northern and southern latitudes, restrict plant growth and, therefore, limit the number of native species in these areas (Fig. 1). For example, northern Florida has $\approx 5000$ native species compared to 1500 in northern Canada. Most tropical plants only grow and reproduce in the temperature range of $18-40 \mathrm{C}$ compared to $8-35 \mathrm{C}$ for temperate species. The time required for acclimation to a stress depends on the stress. Plants acclimate within minutes to a high-temperature stress, producing heat shock proteins (Vierling, 1991). These proteins also are produced in response to numerous other factors, e.g., ethanol, arsenite, heavy metals, glucose starvation, calcium ionophores, etc. (Vierling, 1991). Most heat shock proteins are not produced in response to drought (Kimple and Key, 1985 ), cold (Guy, 1990), anaerobiosis (Russell and Sachs, 1989), and salinity (Harrington and Alm, 1988).

In contrast, low-temperature acclimation (both chilling and freezing) requires days to weeks for maximum stress tolerance to develop. Plants cold-acclimate in response to low temperatures; the temperature of initiation depends on the species. Winter cereals and hardy woody species acclimate at warmer temperatures than spring annual plants. Photoperiod is also involved in the acclimation process for several woody species; its role is associated with the initiation of dormancy. As a general rule, only plants having either a dormancy or a vernalization requirement can acclimate to very low levels. Winter cereals [e.g., Puma rye (Secales cereale L.)] can acclimate to $-30 \mathrm{C}$, whereas spring cereals only acclimate to about -9C. Plants from northern latitudes, which go into dormancy in midsummer, tend to be more winter hardy than southern or coastal species, which enter dormancy in late autumn.

In this review, we summarize recent progress toward understanding the induction and regulation of freezing tolerance in plants. We also review research on the use of plant growth regulators to elucidate the process of acclimation and discuss their potential use to enhance overwintering. Finally, we discuss research on the development of

Received for publication 25 May 1995. Accepted for publication 24 July 1995. The cost of publishing this paper was defrayed in part by the payment of page charges. Under postal regulations, this paper therefore must be hereby marked advertisement solely to indicate this fact. molecular probes that can be used by breeders to select superior genotypes in a segregating population and the potential use of genetic engineering to produce plants with increased tolerance to low temperatures.

\section{NATURAL PLANT GROWTH REGULATORS}

\section{Abscisic acid}

Of all the natural plant growth regulators (PGRs) tested for their effect on freezing tolerance, the application of abscisic acid (ABA) to cell cultures has had the most dramatic effect on increasing freezing tolerance at nonhardening temperatures (Chen and Gusta, 1983; Johnson-Flanagan et al., 1991; Orr et al., 1986; Reaney et al., 1989). Cell cultures of bromegrass (Bromus inermis Leyss) treated with 75 $\mu_{\mathrm{M}}$ racemic $\mathrm{ABA}$ at $25 \mathrm{C}$ increased in freezing tolerance, over 7 days, from $-9 \mathrm{C}$ (control) to greater than $-40 \mathrm{C}$ (Churchill et al., 1992). Gibberellins, which have long been known to inhibit hardening, were

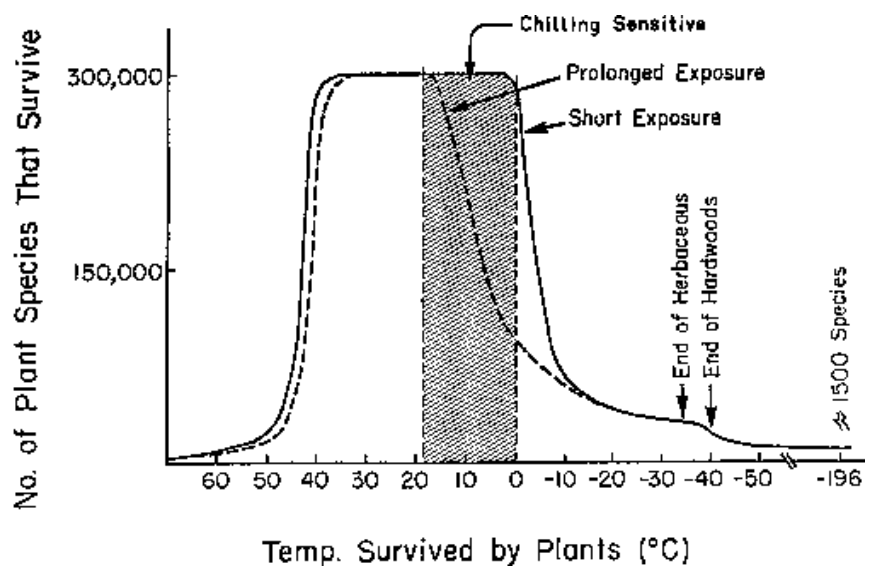

Fig. 1. Plant species distribution as a function of temperature. The solid line indicates a prolonged exposure to the temperature, and the dashed line indicates a short exposure. 
tested for their effect on inhibiting ABA-induced freezing tolerance. Bromegrass cells treated with $75 \mu \mathrm{M}$ racemic ABA for 7 days at $25 \mathrm{C}$ had an $\mathrm{LT}_{50}$ of $-37 \mathrm{C}$ compared to $-11 \mathrm{C}$ for controls (Reaney et al., 1989). Cells treated with $75 \mu \mathrm{M} \mathrm{ABA}$ and 40 to $400 \mu \mathrm{MGA} \mathrm{GA}_{3}$ had $\mathrm{LT}_{50}$ of $-30 \mathrm{C}$. In contrast, cells treated with both $75 \mu \mathrm{M} \mathrm{ABA}$ and $4 \mu \mathrm{M}$ $\mathrm{GA}_{4,7,9}$ for 7 days could only tolerate-20C, a $17 \mathrm{C}$ difference in freezing tolerance compared to $\mathrm{ABA}$ alone. $\mathrm{GA}_{4,7,9}$ at $100 \mu \mathrm{M}$ completely inhibited the $\mathrm{ABA}$ induction of freezing tolerance. The individual gibberellins, $\mathrm{GA}_{4}, \mathrm{GA}_{7}$, and $\mathrm{GA}_{9}$, were as effective as the mixture of $\mathrm{GA}_{4,7,9}$ in reducing ABA-induced freezing tolerance (Reaney et al., 1989).

The effect of kinetin on reducing freezing tolerance was less dramatic than the effect of the gibberellins. During the first 4 days of culture, $100 \mu \mathrm{M}$ kinetin inhibited the ABA-induced freezing tolerance of bromegrass cells by 10C; however, after 8 days of culture, kinetin had no effect. Sakai and Sugawara (1973) observed that cytokinins had no effect on the low-temperature-induced hardening of poplar (Populus euramericana cv. gelrica L.) callus cultures. Orr et al. (1985) reported cytokinins inhibited hardening of alfalfa (Medicago sativa $\mathrm{L}$.) cultures at low temperatures. None of the above studies, however, determined the interaction between ABA and cytokinins on cold acclimation.

\section{Jasmonic acid}

The naturally occurring compounds jasmonic acid (Fig. 2) and its methyl ester are regarded as putative plant growth regulators (Parthier, 1990; Sembdner and Gross, 1986). Both compounds may be involved in the stress response (Creelman et al., 1992; Farmer and Ryan, 1990; Sembdner and Parthier, 1993). Increased levels of these substances occur in response to osmotica, desiccation (Reinbothe et al., 1992a), and wounding (Creelman et al., 1992). Exogenous application of jasmonates induce high levels of mRNAs encoding vegetative storage proteins (Mason and Mullet, 1990), seed storage proteins (Wilen et al.,

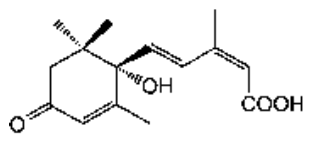

(S)-ABA

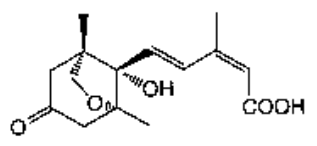

Phaseic acid

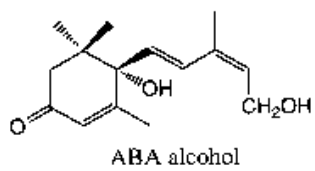

ABA alcohol
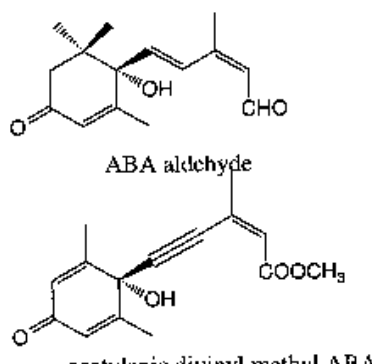

acetwlenie divinyl methyl ABA

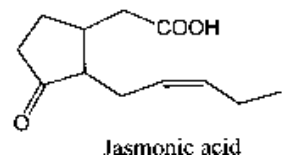

Fig. 2. Structural formulae of jasmonic acid, abscisic acid, and abscisic acid analogs.
1991), and late-embryogenesis abundant (LEA) proteins (Reinbothe et al., 1992a, 1992b). Staswick et al. (1992) reported that a combined application of jasmonic acid and ABA to Arabidopsis seeds greatly increased the inhibitory effect of ABA on germination. Wilen et al. (1994a) also studied the interaction of jasmonic acid and ABA on induction of freezing tolerance in bromegrass cell cultures. Treatment of cells with $75 \mu \mathrm{M} \mathrm{ABA}$ at $25 \mathrm{C}$ was optimal for increasing freezing tolerance, whereas jasmonic acid alone had no detectable effect. Jasmonic acid, in combination with suboptimal concentrations of ABA, however, increased freezing tolerance. These results suggest that certain plant responses, such as cold acclimation, are regulated by a combination of factors that act in concert with each other.

\section{ABA metabolites}

Although it has been demonstrated that racemic ABA increases the stress tolerance of plants, few studies have reported on the effects of optically active (+) or (S) and (-) or (R)-ABA (Fig. 2). While the effects of the natural form (+)-ABA are well documented (Zeevaart and Creelman, 1988), less is known of the effect of the unnatural form, (-)-ABA. Unnatural (-)-ABA is not active in stomatal closure (Walton, 1983); however, it inhibits growth of wheat (Triticum aestivum em Thell.) embryos (Milborrow, 1978), barley (Hordeum vulgare L.) embryos, and excised bean (Phaseolus vulgaris L.) leaves (Walton, 1983), and induces storage protein gene expression in Brassica napus (Wilen et al., 1993). In bromegrass cell cultures, (-)-ABA is degraded much slower than (+)-ABA (Abrams et al., 1989). Reaney and Gusta (1994) have suggested that (-)-ABA is an analog of phaseic acid (PA) (Fig. 2), the first stable carbolyte of ABA, and may interfere with the degradation of (+)-ABA.

Phaseic acid inhibits germination of and $\alpha$-amylase synthesis in barley seeds (Dashek et al., 1979; Nolan and Ho, 1988), but it has no effect on freezing tolerance or gene expression in bromegrass cell cultures (Reaney, 1989; Robertson et al., 1994b). A minor metabolite of ABA, (+)-7'hydroxy ABA (7'OHABA) (Fig. 2), also has been isolated from bromegrass cell cultures (Hampson et al., 1992).

Robertson et al. (1994b) studied the effects of optically active (+)and (-)-ABA, racemic forms of ABA, PA, 7'OHABA, and two precursors of $\mathrm{ABA}$ [ABA alcohol (ABA alc) and $\mathrm{ABA}$ aldehyde (ABA ald), see Fig. 2] on freezing tolerance, growth, water relations, and gene expression in bromegrass cell cultures incubated at $25 \mathrm{C}$ for 7 days. Racemic $( \pm)$-ABA was the most effective at increasing freezing tolerance $\left(\mathrm{LT}_{50}\right.$ less than $\left.-40 \mathrm{C}\right)$, reducing growth (56\% vs. $100 \%$ for control), and lowering the relative cellular water content (70\% vs. $100 \%$ for control). Naturally occurring (+)-ABA was slightly less effective in inducing freezing tolerance, but growth of cells was inhibited less and water content was higher compared to racemic ABA. The (-)-ABA enantiomer was less effective than (+)-ABA (a 18C difference in $\mathrm{LT}_{50}$ ), but growth inhibition and cell water content were similar for both enantiomers. The major catabolite of ABA, PA, had no effect on either freezing tolerance, growth, or cell water content; however, the minor catabolite, $7^{\prime} \mathrm{OHABA}$, was as effective as $(-)-\mathrm{ABA}$ in increasing freezing tolerance and inhibiting growth. The two putative precursors of ABA (Zeevaart and Creelman, 1988), ABA alc and $\mathrm{ABA}$ ald, increased freezing tolerance by 3 and $8 \mathrm{C}$, respectively (Robertson et al., 1994b). These results indicate that (+)-ABA, and not one of its precursors or catabolites, is primarily involved in the induction of freezing tolerance in bromegrass cell cultures.

\section{ABA-analog induction of freezing tolerance in bromegrass cell cultures}

Bromegrass cell cultures have been used as a model system to investigate the structural requirements of the ABA molecule for induction of freezing tolerance (Churchill et al., 1992). Thirty-two analogs were selected that formed an array of systematic alterations to four regions of the molecule. The acid group at C-1 was replaced with either a methyl ester, aldehyde, or alcohol. The cis double bond at C-2, C-3 was replaced with a trans double bond. The trans double bond at $\mathrm{C}-4, \mathrm{C}-5$ was replaced with a triple bond. The double bond in the ring at $\mathrm{C}-2^{\prime}, \mathrm{C}-3^{\prime}$ was replaced with a single bond so that the C-2' methyl 
and side chain were cis. None of the analogs proved to be superior to racemic $\mathrm{ABA}$; however, several analogs with a saturated ring structure and the same steroiosmerization as (+)-ABA were almost as effective as $(+)$-ABA.

Several analogs decreased freezing tolerance of bromegrass cells (L.V.G., unpublished results), and a 2',3' dihydroacetylenic ABA alcohol (DHAcABA alc) (Fig. 2) acted as a competitive inhibitor of ABA-induced freezing tolerance (Wilen et al., 1994b). Originally, Gusta et al. (1990), working with a racemic mixture of this analog, discovered that it stimulated seed germination. Wilen et al. (1993), using microspore-derived embryos of Brassica napus to study ABAsensitive gene expression, found the (-)DHAcABA alc [an isomer with a similar stereochemistry to (-)-ABA at the junction of the ring and side chain] was antagonistic to ABA. The antagonism was observed for the expression of two ABA-sensitive genes, napin and oleosin. In freezing tolerance studies using the bromegrass cultures, Wilen et al. (1994b) found that adding (-)DHAcABA alc before treatment with racemic $\mathrm{ABA}$ reduced the level of $\mathrm{ABA}$-induced freezing tolerance. For example, the addition of $2.5 \mu \mathrm{M}( \pm)-\mathrm{ABA}$ resulted in an $\mathrm{LT}_{50}$ of $-15 \mathrm{C}$, but when $\mathrm{ABA}$ was added after the addition of 20 or $50 \mu \mathrm{M}(-)$ DHAcABA alc, the freezing tolerance of the cells was equivalent to the control cells (about $\approx 8 \mathrm{C}$ ). When the concentration of $(+)$-ABA was increased, full freezing tolerance was restored, even in the presence of high concentrations of the analog. The $(+)$ enantiomer of this analog behaved similarly to (+)-ABA, although it was not as effective as (+)-ABA. Interestingly, (-)DHAcABA alc was a more effective inhibitor of (-)-ABA than (+)-ABA. As stated earlier, (-)-ABA increases the freezing tolerance of bromegrass cells to-19C (Robertson et al., 1994b). Unlike (+)-ABA, (-)DHAcABA alc completely inhibits (-)-ABA-induced freezing tolerance in bromegrass cells. Use of analogs provides helpful tools for elucidating the mechanism of freezing tolerance. In a later section, we again discuss the use of these analogs to study ABA-induced gene expression.

\section{SYNTHETIC PLANT GROWTH REGULATORS}

PGRs that have been shown to increase cold hardiness or winter survival are primarily antigibberellin-type compounds. [For a comprehensive review, see Carter and Brenner (1985).] Several PGRs, including the triazoles, act as antigibberellins by inhibiting the cytochrome P-450-mediated monoxygenase reactions involved in the isoprenoid pathway. Triazoles confer stress tolerance to chilling (Whitaker and Wang, 1987), heat (Pennypacker et al,. 1982), drought (Fletcher and Hofstra, 1985), and freezing (Gusta et al., 1990). Triazoles that confer the most stress tolerance are triadimefon, tridimenol, paclobutrazol, and uniconazole.

A fall, foliar application of (2-chloroethyl)-trimethylammonium chloride (cycocel), terpal C [a mixture of (2-chloroethyl)trimethylammonium chloride and (2-chloroethyl) phosphoric acid], $N$-\{2,4-dimethyl-5-[[(trifloromethyl)sulphonyl]amino]phenyl $\}$ acetamide (mefluidide), or 1-(4-chlorophenoxy)-3,3-dimethyl-1(1H-1,2,4triazol-1-yl)-2-butanone (triadimefon) retarded the loss of freezing tolerance in crowns of winter barley and winter wheat from January to March (Gusta et al., 1988). This period is a critical time for survival. For unknown reasons, winter cereals, especially the less-hardy genotypes, slowly lose their freezing tolerance from January to March even though they are constantly exposed to subzero temperatures. In 5 years of field testing, fall-applied PGR resulted in an increase in the average winter survival of plants. These effects, however, were not consistent from year to year. Morrison and Andrews (1992) also obtained inconsistent effects on freeze tolerance and winter survival when triazoles were applied in the fall on rape plants (Brassica napus L.). Anderson et al. (1985) reported tetcyclasis applied as a seed treatment improved the survival of winter oat (Avena sativa $\mathrm{L}$.) by reducing the length of the subcrown internode. Gusta et al. (1994) applied $\beta$-(4chlorophenyl)-3,4,5,9,10-pentaaza-tetracyclo-5,4,1,0 $0^{2,6}, 0^{8,11}$-dodeca3,9-diene (Baytan; triadimenol); 1- $\mathrm{N}$-propyl- $\mathrm{N}$-[2-(2,4,6trichlorophenoxy)-ethyl] (Sportak; prochloraz), alone or in combination with 1-[2,4-dichlorophenyl-2-(propanyloxy)ethyl] $1 H$-imidazole nitrate (imazalil); 5-(4-chlorophenyl)-3,4,5,9,10-pentaaza-tetracyclo$\left.5,4,1,0^{2,6}, 0^{8,1}\right]$ dodeca-3,9-diene (Bas-106W; tetcylasis); and 5,6- dihydro-2-methyl- $N$-phenyl-1,4-oxathiin-3-carboxamide (Vitavax; carbathiim) to seeds of a semidwarf and a tall-type winter wheat. None of the treatments increased the freezing tolerance of the crowns, and several rates of the treatments reduced both freezing tolerance and winter survival.

Mevalonic acid is the putative precursor to GAs and ABA via the isoprenoid pathway. While several PGRS are known to inhibit GA biosynthesis at specific steps in the isoprenoid pathway, Norman et al. (1986) demonstrated that the triazole ( $2 R S, 3 R S)$-1-(4-chlorophenyl)4,4-dimethyl-2-(1H-1,2,4-triazol-1-yl)pentan-3-ol (paclobutrazol) inhibited ABA biosynthesis in the fungus Cereospora rosicola Passerini. Application of triadimefon induced a transient increase in endogenous ABA in beans (Asare-Boamah et al., 1986). These results suggest that the pathways of ABA biosyntheses may differ between fungi and plants. Tetcyclasis increases $\mathrm{ABA}$ in leaves by inhibiting the C-8'-hydroxylation of ABA to phaseic acid (Zeevaart et al., 1990). In a 2-year field study, Massie and Gusta (unpublished) obtained inconsistent results on freezing tolerance or winter survival of winter wheat and winter barley following foliar applications of racemic ABA and SABA, each alone, and in combination with paclobutrazol, tetcyclasis, or triadimefon. Possible reasons for the inconsistency are temperature of application, time of application, and growth conditions following application. Also, only a certain level of ABA possibly is required for the initiation of cold hardiness, and further increases as a result of a PGR treatment are of no value.

\section{ABA induction of freezing tolerance in plants}

The role of ABA in the induction of cold acclimation still remains equivocal. Chen et al. (1983) suggested that low temperatures triggered a transient increase in ABA, which, in turn, mediated changes in gene expression associated with low-temperature acclimation. Endogenous ABA levels increase in response to low temperatures and appear to be correlated with an increase in freezing tolerance (Chen et al., 1992; Dörfling et al., 1990; Machackova et al., 1989; Taylor et al., 1990). In contrast, Dallaire et al. (1994) did not detect an increase in ABA levels in the leaves of winter wheat during low-temperature acclimation. Large ABA pools are sequestered in plants in structures (e.g., plastids) where they are not biologically active. The concentration of ABA at the receptor site, which transduces the signal into an observed biological response, is difficult to measure. Therefore, it is possible to have an $\mathrm{ABA}$ response without detecting a change in total plant ABA. In most studies, ABA is quantified by measuring bulk concentrations, which can give misleading results if the phytohormone is compartmentalized. A good example of this problem has been demonstrated in stomata. High concentrations of ABA may occur in guard cells (Behl and Hartung, 1986; Brinckman et al., 1990); however, the stomata remain open because the ABA is sequestered away from the receptors on the plasma membrane (Hartung, 1983).

Exogenous ABA can partially cold-acclimate plants (Churchill, 1992; Lang et al., 1989) (Table 1), but not to the same hardiness level as induced by low temperatures. A foliar application of $75 \mu \mathrm{M}$ ABA to Puma rye seedlings (two- to three-leaf stage) grown at nonacclimating temperatures increased the freezing tolerance of the crowns by $2 \mathrm{C}$ (Churchill, 1992). In contrast, a root-drench application lowered the $\mathrm{LT}_{50}$ from -3 to -7 to $-9 \mathrm{C}$ three days after application, but the effect decreased to control level by 6 days after application. If ABA is applied to germinated rye (Secale cereale $\mathrm{L}$.) seedlings that are 2 days old, and

Table 1. Influence of growth conditions on the freezing tolerance $\left(\mathrm{LT}_{50}{ }^{\circ} \mathrm{C}\right)$ of 'Puma' rye crowns.

\begin{tabular}{lc}
\hline \hline Growth conditions & $\mathrm{LT}_{50}{ }^{\circ} \mathrm{C}$ \\
\hline Vermiculite, 25C & -2 \\
Sandy loam soil, 25C & -5 \\
Hydroponics, 25C & -5 \\
Field (summer), 20-25C & -9 \\
Drought stress, 25C & -7 \\
$100 \mu \mathrm{m}$ ABA (foliar), 25C & -4 \\
$100 \mu \mathrm{m}$ ABA (root-drench), 25C & -8 \\
Controlled environment, 2C & -28 \\
Field (autumn) & -34 \\
\hline
\end{tabular}


still dependent on seed reserves, the $\mathrm{LT}_{50}$ is increased to $-15 \mathrm{C}$ (MacHutchon, 1991).

Due to cuticular resistance, exogenous uptake of ABA through the leaves is very slow (Blumenfeld and Bukovac, 1972; Friedlander et al., 1976). Translocation is also very slow or negligible. Shindy et al. (1973) foliarly applied ${ }^{14} \mathrm{C}$-labeled $\mathrm{ABA}$ and found that $80 \%$ of the radiolabel had remained in the treated leaves after 8 days. In contrast, ABA applied to roots is readily absorbed (Chanson and Pilet, 1982; Markhart, 1982) and translocated (Chanson and Pilet, 1982; Hartung, 1977). Foliarly applied ABA is mainly translocated in the phloem (Shindy et al., 1973) to photosynthetic sinks (Hartung, 1977); therefore, the lack of a response to foliarly applied ABA may be due to poor uptake and failure for it to be translocated to the ABA receptor(s) that mediate cold hardening.

A series of Arabidopsis mutants either deficient in ABA or insensitive to ABA have been used to study the role of ABA in inducing freezing tolerance. A mutant impaired in ABA biosynthesis was unable to cold-acclimate unless treated with exogenous ABA (Heino et al., 1990). Gilmour and Thomashow (1991) found that mutants with low levels of ABA acclimated less than the wild type, while a mutant insensitive to ABA cold-acclimated to temperatures similar to those for the wild type.

Studies have shown certain genes thought to be involved in the development of freezing tolerance are induced at low temperatures, but not in ABA-deficient and ABA-insensitive mutants (Gilmour and Thomashow, 1991; Nordin et al., 1991). In Brassica napus, a transcript, which was detected in low-temperature-acclimated shoots, was not detected in response to exogenous ABA (Weretilnyk et al., 1993). Generally, there is a certain degree of regulatory commonality in genes induced by low temperature, drought, and ABA. Wolfraim et al. (1993), however, studying expression and transcript stability in coldacclimated alfalfa, reported that neither drought nor ABA induced a low-temperature-regulated transcript. Recently, Jarillo et al. (1993) also demonstrated a cold-inducible transcript that is not induced by either ABA or water stress.

Nordin et al. (1991) found that the ABA biosynthesis inhibitor fluridone did not prevent the low-temperature induction of a coldhardiness-related transcript in Arabidopsis. Since Arabidopsis coldacclimates very rapidly and cold-induced proteins appear within $6 \mathrm{~h}$ of cold exposure (Nordin et al., 1991), it is conceivable that existing pools of ABA could induce cold hardiness-related transcripts even in the presence of fluridone. Collectively, these studies raise the possibility that both ABA-dependent and ABA-independent signal transduction pathways exist for the induction of freezing tolerance (Dallaire et al., 1994; Gilmour and Thomashow, 1991; Nordin et al., 1991).

In the above studies, it is difficult to determine which of the coldinduced transcripts are causally related to low-temperature-induced tolerance. Many of the identified transcripts may be related to cold shock and adjustment to growth at low temperatures. Several studies have shown that low-temperature-induced transcripts disappear within $24 \mathrm{~h}$ at nonacclimating temperatures (Guo et al., 1992; Hajela et al., 1990; Jarillo et al., 1993). To our knowledge, no research has been reported on how fast these cold-induced gene products disappear under warm conditions and if they correlate with dehardening. Winter cereals still maintain a fairly high level of freezing tolerance, even after being exposed to nonacclimating temperatures. For example, hardy winter rye with an initial $\mathrm{LT}_{50}$ of $-24 \mathrm{C}$ has an $\mathrm{LT}_{50}$ of $-14 \mathrm{C}$ after 6 days at 15C (Gusta and Fowler, 1976).

\section{ABA-analog induction of freezing tolerance in plants}

Churchill (1992) studied the induction of freezing tolerance in Puma rye seedlings in the two- to three-leaf stage using a systematic assay of analogs described in the section on bromegrass cell cultures. A foliar application of ABA and the ABA analogs had only a marginal effect on freezing tolerance; the greatest increase in freezing tolerance was measured following a root application. None of the analogs were as effective as ABA 3 days after application; however, several analogs were more effective than ABA 6 days after application. An analog with an acetylenic side chain and a dihydro analog with an acetylenic side chain (Fig. 2) increased the freezing tolerance of the crowns to $-9 \mathrm{C}$ compared to $-3 \mathrm{C}$ for the controls and ABA-treated plants 6 days after application. The study demonstrated that molecular substitutions have differing effects on analog activity that depend on the presence of other functional groups on the molecule. For example, (+)ABA and acetylenic ABA analogs were highly active, but of their $2^{\prime}, 3^{\prime}$-dihydro counterparts (unsaturated ring), only those with the same sterochemistry of (+)ABA remained active. Introduction of an acetylenic side chain in the dihydro series also increased the activity of the acid and ester but not of the aldehyde or alcohol (Robertson et al., 1993).

A combination of either tetcyclasis or mefluidide with ABA did not increase the ability of ABA to increase the freezing tolerance of rye seedlings (Churchill, 1992). Continuous feeding of ABA to the root also did not increase the freezing tolerance of the seedlings. In conclusion, none of the treatments at nonhardening temperatures could increase the freezing tolerance of rye seedlings at the two- to three-leaf stage beyond $-9 \mathrm{C}$, whereas exposure to low temperatures resulted in an $\mathrm{LT}_{50}$ of $-30 \mathrm{C}$.

Wilen et al. (1994c) determined the effect of six racemic mixtures of ABA analogs on seedlings of Brassica napus L. and B. campestris L. grown at 10C. In B. napus, freezing tolerance could be increased $2 \mathrm{C}$ through the application of ABA aldehyde, $3^{\prime}$ dihydro ABA, or acetylenic divinyl methyl-ABA (Fig. 2). In B. campestris, 2',3' dihydro ABA, 2'3' acetylenic dihydro ABA, and acetylenic divinyl methyl$\mathrm{ABA}$ (Fig. 2) only increased frost tolerance by $1.5 \mathrm{C}$. Surprisingly, both 2',3' dihydro ABA and acetylenic divinyl ABA advanced flowering by 2 to 3 days in both species.

\section{Role of sugars in freezing tolerance}

Cell cultures of bromegrass incubated at $25 \mathrm{C}$ in Erikson's medium containing $3 \%$ sucrose can tolerate $-9 \mathrm{C}$; however, cells can tolerate $-40 \mathrm{C}$ if treated with $100 \mu \mathrm{M} \mathrm{ABA}$ (Reaney and Gusta, 1987). (-)-ABA, in contrast to (+)-ABA, only hardens cells 9 to $10 \mathrm{C}$, although both enantiomers result in a similar accumulation of ABA-responsive proteins. One major difference between $(+)$ and $(-)$-ABA is that $(+)$-ABA results in a three-fold increase in sucrose over the control and (-)-ABA-treated cells (Wilen et al., 1994b). The accumulation of sucrose in response to $\mathrm{ABA}$ has been demonstrated in a variety of tissues (John and Yamaki, 1994); however, to our knowledge, the Wilen et al. (1994b) report is the first to distinguish a difference between the two enantiomers.

Sugars are strongly correlated with freezing tolerance (Anderson, 1944; Dexter, 1933; Levitt, 1980; Sakai, 1962). Fowler et al. (1981), studying winter wheat cultivars varying in freezing tolerance, obtained a correlation coefficient of 0.88 between cold hardiness and crown sucrose concentration. Also, there was a high correlation $(0.91)$ between sucrose content, prostrate growth habit, and freezing tolerance. Less-hardy winter cereals have an upright growth habit and lower sugar content even though they have a vernalization requirement. GA, which is known to decrease freezing tolerance, also reverts the prostrate growth habit to an upright form and decreases the sucrose content in Paspalum vaginatum SW. (Willenöes et al., 1988). Application of $\mathrm{GA}_{3}$ also prevents prostrate growth habit in Trifolium fragiferum L. (Bendixen and Petersen, 1962) and in Proserpinaca palustris (Wallenstein and Albert, 1963).

There is a strong positive relationship between freezing tolerance and vernalization requirement in winter cereals (Doll et al., 1989; Schmütz, 1978). Once the vernalization requirement is met, dehardened winter cereals cannot be rehardened beyond -9C (Gusta, unpublished results). Even under hardening conditions, these plants assume an upright growth habit because they have switched from a vegetative phase to a reproductive phase. Unlike their winter counterparts, spring cereals do not assume a prostrate growth habit even when sown in the autumn. All of their photosynthetic reserves are used for growth rather than being stored, as observed for winter cereals. There is also a strong correlation between the onset of dormancy and cold hardiness in trees (Smithberg and Weiser, 1968). In both of these examples, the plants are in a vegetative growth stage and are actively accumulating carbohydrate storage reserves, primarily in the form of sugars.

Sucrose is often the main sugar associated with hardiness, but not for all species. For example, fructosans accumulate in grasses (Smith, 
1968), raffinose is the main sugar in Ajuga reptans (Bachmann et al., 1994), and polyhydric alcohols, e.g., sorbitol or mannitol, may account for $40 \%$ of the total carbohydrate in species of Gardenia and Sorbus (Sakai, 1966). Olien (1967) demonstrated that carbohydrates in the apoplast interfered with ice crystal growth and reduced mechanical injury associated with freezing. Sugars are known to protect cells and membranes (Levitt, 1980; Sakai, 1962). Trehalose functionally replaces water bound to membranes and proteins and thus confers structural stability during desiccation (Crowe et al., 1984). The soluble sugars sucrose, stachyose, and raffinose play a role in vitrification, which helps protect plants from freezing injury and embryos from desiccation injury (Hirsh, 1987; Koster, 1991). Recently, Blackman et al. (1992) postulated that seed maturation proteins, such as the heatstable LEA proteins, act in conjunction with sugars to provide desiccation protection to seeds during maturation.

Robertson et al. (1994a) found ABA-responsive, heat-stable proteins extracted from bromegrass cell suspension cultures reduced the heat-induced coagulation of protein extracts. The addition of sucrose $(8 \%)$, in combination with ABA-responsive, heat-stable proteins, dramatically increased the stability of protein extracts to heat-induced coagulation. These results suggest that sugars, such as sucrose, and heat-stable proteins function in concert and, therefore, protect sensitive proteins and membranes against stress-induced denaturation.

\section{HEAT-STABLE PROTEINS}

Heat-stable proteins (i.e., proteins that remain soluble when boiled) have been isolated from dry seeds (Baker et al., 1988), water-stressed plants (Close et al., 1989), cold-acclimated plants (Houde et al., 1992), and saline-stressed plants (Kononowicz et al., 1993). These proteins are thought to prevent dehydration damage to membranes and proteins by solvating cellular constituents (Close and Chandler, 1990), and by acting as osmoprotective proteins, desiccation-damage repair proteins (Dure et al., 1989), and antifreeze agents (Volger and Heber, 1975). They are very hydrophillic, rich in glycine or alanine and charged amino acids, and have random coil structural motifs (Dure et al., 1989). Heat-stable proteins are induced by one or more of the following: dehydration, cold, salinity, heat, and ABA (see Wilen et al., 1994d).

Houde et al. (1992) isolated a heat-stable, 50-kD protein (Wcs120) from cold-acclimated wheat that had two domains also found in barley dehydrins (Close et al., 1989). Using genotypes of wheat differing in freezing tolerance, they found a correlation between Wcs120 accumulation and freezing tolerance. Jinn et al. (1989) demonstrated that certain low-molecular-weight, heat-shock proteins, which are heat stable, confer in vitro heat tolerance to thermosensitive proteins. Similarly, Hincha et al. (1990) confirmed the earlier findings of Volger and Heber (1975) that heat-stable proteins between 10 and $20 \mathrm{kD}$, isolated from cabbage (Brassica oleracea L. Capitata Group), cryoprotected thylakoid membranes from freezing injury. ABAresponsive, heat-stable proteins isolated from ABA-treated bromegrass cells enhanced the thermal stability of control protein isolates (Robertson et al., 1994a). All of the above results indicate that heatstable proteins, in combination with sugars and possibly other compounds, play a role in stress tolerance.

\section{Expression of dehydrin and WCS genes in spring and winter cereals}

Transcripts encoding dehydrin genes can be detected by Northern analysis in hydroponically grown plants within $48 \mathrm{~h}$ of exposure to low temperature (Robertson et al., 1994c). Induction of gene expression by cold occurs in spring and winter cereals, whether they are grown in hydroponics or in the field (Fu et al., 1994; Robertson et al., 1994c). Thus, the response of these genes to cold is independent of genotype. Slot blot analysis of RNA isolated from hydroponically grown spring and winter cultivars of rye (Cereale secale L.), wheat (Triticum aestivum L.), and barley (Hordeum vulgare L.), however, indicates there is a difference in the pattern of expression between the spring and winter genotypes. Dehydrin and wcs 120 transcripts can be detected within $48 \mathrm{~h}$ of transfer to low temperature in spring and winter cereals. In spring cereals, however, the transcripts encoding these genes disappear within 7 to 14 days in hydroponics. In contrast, winter cereals maintain high levels of the transcripts for at least 49 days.

$\mathrm{Fu}$ et al. (unpublished), working with winter and spring ryes, wheats, and barleys, also found a high correlation between the presence of heat-stable proteins and freezing tolerance. Several of the heatstable proteins from these winter types strongly cross-reacted with an antidehydrin antibody. A barley dehydrin cDNA ( $d h n-4$; Close et al., 1989) was used to study the expression of dehydrin-related transcripts isolated from field-acclimated winter and spring varieties of wheat, rye, and barley (Fu et al., 1994). Transcripts isolated from winter cereals increased from September to November and reached maximum level at maximum hardness. Dehydrin transcripts were present in spring genotypes harvested in October, but at a lower level compared to the winter cultivars, and by November declined to a level similar to nonacclimated tissue.

Proteins detected by anti-Wcs 120 antibodies accumulate in spring and winter types, but they are degraded in spring wheat varieties after an extended exposure to low temperature. Similar results were obtained in a study of winter wheat varieties with differing freezing tolerance (Matsuda et al., 1994). Thus, there appears to be a correlation between the accumulation of dehydrin, Wcs, other heat-stable proteins, and freezing tolerance (Robertson et al., 1994b).

The difference in expression pattern between spring and winter genotypes is a result of either transcriptional or post-transcriptional regulation. As very little transcriptional activity likely occurs in fieldgrown plants at subzero temperatures during late November (typical temperature range -10 to $-40 \mathrm{C}$ ), it is more probable that posttranscriptional processes are responsible for the observed difference in spring and winter cereals' transcript levels. The view that posttranscriptional regulation is involved in cold-induced gene expression has been expressed by other researchers (Gilmour and Thomashow, 1991; Matsuda et al., 1994; Weretilnyk et al., 1993).

\section{Improvement of freezing tolerance by genetic engineering}

Cold acclimation of plants triggers numerous physiological and biochemical changes (Guy, 1990; Levitt, 1980). Many genes are involved in these processes and are proposed to confer freezing tolerance. Therefore, it seems highly unlikely that the introduction of one or two genes, thought to be associated with freezing tolerance, will result in a marked increase in hardiness. Also, as discussed earlier, less-hardy plants, e.g., spring cereals, may contain the same genes as the hardy winter types, except they are only transiently expressed or the mRNAs are not stable. Additionally, it appears that the continual accumulation of photosynthates is associated with the development of full hardiness potential. Thus, to genetically engineer a superior, winter-hardy plant all of the above may have to be considered.

The first attempt to increase freezing tolerance of plants through genetic engineering was to transform plant cells with flounder (Pseudopleuronectes americanus L.) antifreeze protein genes (Georges et al., 1990; Hightower et al., 1991; MacHutchon et al., 1991). Increased freezing tolerance of the transgenic plants, however, was only marginal. MacHutchon et al. (1991) reported that transgenic tobacco (Nicotiana tabacum L. 'Xanthi') transformed with two types of fish-antifreeze protein (AFP type II and AFP type III) genes survived freezing to -3.5 and $-4.5 \mathrm{C}$, only 1 to $1.5 \mathrm{C}$ more freezing tolerant than control, nontransformed regenerates. As antifreeze proteins inhibit ice recrystallization, extracts from transgenic plants limit ice crystal formation during the commercial freeze processing of fruit (Hightower et al., 1991).

Arabidopsis cor genes are a group of cold-regulated genes proposed to have various functions in the acquisition of freezing tolerance (Lang and Palva, 1992; Lin and Thomashow, 1992). Proteins encoded by the cor 15 gene protected the cold-labile enzyme, lactate dehydrogenase, against low-temperature (freezing) denaturation and inactivation (Lin and Thomashow, 1992). Recently, transformation with a cor15a-reporter gene construct (Artus et al., 1994) showed Cor15a was localized in the soluble fraction of chloroplasts. Over-expression of this protein in nonacclimated, transgenic Arabidopsis plants did not result in enhanced freezing tolerance (Artus et al., 1994). PSII photochemical efficiencies of these COR 15 over-producers, however, were 
significantly different than nonacclimated, wild-type plants after freezing to -4 and $-5 \mathrm{C}$, indicating COR15A may play a role in protecting chloroplasts during freezing.

Superoxide dismutase (SOD) is required for the removal of the toxic superoxide free radicals produced as a result of environmental stress. Over-expression of SOD protein is proposed to improve freezing tolerance of plants, and transformation of alfalfa (Medicago sativa L.) with a mitochondrial and chloroplast Mn-SOD-gene from $N$. plumbaginifolia has been reported (McKersie et al., 1993). These transgenic plants exhibit greater total SOD activity in leaves and greater regrowth rate based on shoot dry matter production after a freezing stress. Over-expression of a pea (Pisum sativum L.) plastid $\mathrm{Cu} / \mathrm{Zn}$-SOD gene in transgenic tobacco and petunia (Petunia hybrida Vilm.) substantially reduced damage to the photosynthetic apparatus during low-temperature/high-light growth conditions and enhanced recovery of photosynthesis following a freeze-thaw cycle (Sen Gupta et al., 1993).

In general, a dramatic enhancement of freezing tolerance has not been achieved by genetic engineering of plants with cold-regulated genes. The ineffectiveness of the cold- or dehydration-responsive genes in transgenic plants likely is due to the fact that freezing tolerance is a complex trait involving multiple genes and numerous physiological and biochemical changes. For example, changes in gene expression during low-temperature acclimation result in membrane unsaturation and accumulation of sugar, protein, nucleic acids, osmolytes, hormones, etc. These events are thought to regulate the time and rate of acclimation, the level of hardiness attained, the maintenance of hardiness through the winter months, and the rate of hardiness loss due to warm spring weather. Other factors involved in survival are resistance to winter pathogens, ice encasement, flooding, and desiccation. Over-expression of a single gene could result in only a small or undetectable increase in freezing tolerance. Lack of progress in increasing freezing tolerance with conventional breeding techniques, and advances in our knowledge of gene regulation and molecular biology, will continue to make genetic engineering an attractive and plausible approach.

\section{Literature Cited}

Abrams, S.R., M.J.T. Reaney, G.D. Abrams, T. Mazurek, A.C. Shaw, and L.V. Gusta. 1989. Ratio of (S)- to (R)-abscisic acid from plant cell cultures supplied with racemic ABA. Phytochemistry 28:2885-2889.

Anderson, G. 1944. Gas exchange and frost hardening studies in winter cereals. PhD Diss., Univ. of Lund, Lund, Sweden.

Anderson, H.M., N.D.S. Huband, P.J. Murphy, and R.D. Child. 1985. Improving winter hardiness in winter oats by seed treatment with tetcyclasis. Proc. British Crop Protection Conf. Weeds 4C-25:569-573.

Artus, N.N., S.J. Gilmour, C. Lin, and M.F. Thomashow. 1994. Use of transgenic Arabidopsis plants to evaluate the roles of cold-regulated genes in freezing tolerance. Plant Physiol. 105:169.

Asare-Boamah, N.K., G. Hofstra, R.A. Fletcher, and E.B. Dumbroff. 1986. Triadimefon protects beans from water stress through its effects on ABA. Plant Cell Physiol. 217:383-390.

Bachmann, M., P. Matile, and F. Keller. 1994. Metabolism of the raffinose family oligosaccharides in leaves of Ajuga reptans L. Plant Physiol. 105:1335-1345.

Baker, J., C. Steele, and L. Dure. 1988. Sequence and characterization of 6 Lea proteins and their genes from cotton. Plant Mol. Biol. 11:277-291.

Behl, R. and W. Hartung. 1986. Movement and compartmentation of abscisic acid in guard cells of Valerianella locusta: Effects of osmotic stress, external $\mathrm{H}^{+}$-concentration and fusicoccin. Planta 168:360-368.

Bendixen, L.E. and M.L. Petersen. 1962. Physiological nature of gene-controlled growth form in Trifolium fragiterum L. II. Auxin-gibberellin relationships to growth form. Plant Physiol. 37:245-250.

Blackman, S.A., R.L. Obendorf, and A.C. Leopold. 1992. Maturation proteins and sugars in desiccation tolerance of developing soybean seeds. Plant Physiol. 100:225-230.

Blumenfeld, A. and M.J. Bukovac. 1972. Cuticular penetration of ABA. Planta 107:261-268.

Brinckmann, E., W. Hartung, and W. Wartinger. 1990. Abscisic acid levels of individual leaf cells. Physiol. Plant. 80:51-54.

Carter, J.V. and M.L. Brenner. 1985. Plant growth regulators and low temperature stress, p. 418-433. In: R.P. Pharis and D.M. Ried (eds.). Encyclopedia of plant physiology new series. vol. II. Springer-Verlag, Berlin.
Chanson, A. and P.E. Pilet. 1982. Transport and metabolism of $\left[2-{ }^{14} \mathrm{C}\right]$ abscisic acid in maize root. Planta 154:556-561.

Chen, H.H., P.H. Li, and M.I. Brenner. 1983. Involvement of abscisic acid in potato cold acclimation. Plant Physiol. 71:362-365.

Chen, T.H.H. and L.V. Gusta. 1983. Abscisic acid-induced freezing resistance in cultured plant cells. Plant Physiol. 73:71-75.

Chen, T.H.H., B. Zhu, and P.H. Li. 1992. Complimentary DNA cloning of $\mathrm{ABA}$ regulated genes associated with the induction of freezing tolerance in potato (Solanum commersonii). Plant Physiol. 99:S-126.

Churchill, G.C. 1992. Abscisic acid and abscisic acid analog induced freezing tolerance in winter rye (Secale cereale L) seedlings. MS Thesis, Univ. of Saskatchewan, Saskatoon, Canada.

Churchill, G.C., B. Ewan, M.J.T. Reaney, S.R. Abrams, and L.V. Gusta. 1992. Structure-activity relationships of abscisic acid analogs based on the induction of freezing tolerances in bromegrass (Bromus inermis Leyss) cell culture. Plant Physiol. 100:2024-2029.

Close, T.J. and P.M. Chandler. 1990. Cereal dehydrins: Serology, gene mapping and potential functional roles. Austral. J. Plant Physiol. 17:333-344.

Close, T.J., A.A. Kortt, and P.M. Chandler. 1989. A cDNA-based comparison of dehydration-induced proteins (dehydrins) in barley and corn. Plant Mol. Biol. 13:95-108.

Creelman, R.A., M.L. Tierney, and J.E. Mullett. 1992. Jasmonic acid/methyl jasmonate accumulate in wounded soybean hypocotyls and modulate wound gene expression. Proc. Natl. Acad. Sci. USA 89:4938-4941.

Crowe, J.H., L.M. Crowe, J.F. Carpenter, A.S. Rudolf, C.A. Wistrom, B.J. Spargo, and T.J. Anchordoguy. 1984. Interaction of sugars with membranes. Biochim. Biophys. Acta 947:367-384.

Dallaire, S., M. Houde, Y. Gagne, H.S. Jaini, S. Boileau, N. Chevrier, and F. Sarhan. 1994. ABA and low temperature induce freezing tolerance via distinct regulatory pathways in wheat. Plant Cell Physiol. 35:1-9.

Dashek, W.V., B.W. Singh, and D.C. Walton. 1979. Abscisic acid localization and metabolism in barley aleurone layers. Plant Physiol. 64:43-48.

Dexter, S.T. 1933. Effect of several environmental factors on the hardening of plants. Plant Physiol. 8:123-139.

Doll, H., V. Haahr, and B. Søgaard. 1989. Relationship between vernalization requirement and winter hardiness in doubled haploids of barley. Euphytica 42:209-213.

Dörffling, K., S. Schulenburg, G. Lesselich, and H. Dörfling. 1990. Abscisic acid and proline levels in cold hardened winter wheat leaves in relation to variety-specific differences in freezing resistance. J. Agr. Crop Sci. 165:230239.

Dure, III, L., M. Crouch, J. Harada, T.H.D. Ho, J. Mundy, R. Quatrano, T. Thomas, and Z.R. Sung. 1989. Common amino acid sequences domains among the LEA proteins of higher plants. Plant Mol. Biol. 12:475-486.

Farmer, E.E. and C.A. Ryan. 1990. Interplant communication: Airborne methyl jasmonate induces synthesis of proteinase inhibitors in plant leaves. Proc. Natl. Acad. Sci. USA 87:7713-7716.

Fletcher, R.A. and G. Hofstra. 1985. Triadimefon a plant multi-protector. Plant Cell Physiol. 26:775-780.

Fowler, D.B., L.V. Gusta, and N.J. Tyler. 1981. Selection for winter hardiness in wheat and screening methods. Crop Sci. 21:896-901.

Friedlander, M., D. Atsmon, and E. Galun. 1976. Uptake, transport and stability of $\left[2-{ }^{14} \mathrm{C}\right]$ abscisic acid in cucumber following foliar application. Plant Cell Physiol. 17:965-972.

Fu, P., A.J. Robertson, A. Weninger, R.W. Wilen, B.J. O'Connor, and L.V. Gusta. 1994. Differential expression of dehydrins in spring and winter cereals during cold acclimation. Plant Physiol. 105S:169.

Georges, F., M. Saleen, and A.J. Cutler. 1990. Design and cloning of synthetic gene for the flounder antifreeze protein and its expression in plant cells. Gene 91:159-165.

Gilmour, S.V. and M.F. Thomashow. 1991. Cold acclimation and coldregulated gene expression in ABA mutants of Arabidopsis thaliana. Plant Mol. Biol. 17:1233-1240.

Graham, D. and B.D. Patterson. 1982. Responses of plants to low, nonfreezing temperatures: Proteins, metabolism, and acclimation. Annu. Rev. Physiol. 33:347-372.

Guo, W., R.W. Ward, and M.F. Thomashow. 1992. Characterizations of a coldregulated wheat gene related to Arabidopsis cor47. Plant Physiol. 100:915922.

Gusta, L.V. and D.B. Fowler. 1976. Effects of temperature on dehardening and rehardening of winter cereals. Can. J. Plant Sci. 56:673-678.

Gusta, L.V., B.J. O'Connor, G.P. Lafond, and H.M. Austenson. 1994. The effect of fungicides and plant growth regulators applied as a seed treatment on the freezing tolerance of winter wheat. Can. J. Plant Sci. 74:63-69.

Gusta, L.V., B.J. O'Connor, and M.J.T. Reaney. 1988. The effect of growth regulators on the winter survival of winter wheat, p. 531-536. In: R.P. Pharis (ed.). Plant growth substances 1988. Springer-Verlag, Berlin.

Gusta, L.V., M.J.T. Reaney, S.R. Abrams, A.J. Robertson, and G.D. Abrams. 1990. Abscisic acid analogs. Biological activity and interactions with the 
plant growth regulator abscisic acid. Comments Agr. Food Chem. II(2):143169.

Guy, C.L. 1990. Cold acclimation and freezing stress tolerance. Role of protein metabolism. Annu. Rev. Plant Physiol. Plant Mol. Biol. 41:187-223.

Hajela, R.K., D.P. Horvath, S. Gilmour, and M.F. Thomashow. 1990. Molecular cloning and expression of cor (cold-regulated) genes in Arabidopsis thaliana. Plant Physiol. 93:1246-1252.

Hampson, C.R., M.J.T. Reaney, G.D. Abrams, S.R. Abrams, and L.V. Gusta. 1992. Metabolism of (+)-abscisic acid to (+)-7'-hydroxy abscisic acid by bromegrass cell cultures. Phytochemistry 31:2645-2648.

Harrington, H.M. and D.M. Alm. 1988. Interaction of heat shock and salt shock in cultured tobacco cells. Plant Physiol. 88:618-625.

Hartung, W. 1977. Transport of $\left[2-{ }^{14} \mathrm{C}\right]$ abscisic acid from the root system of intact seedlings of runner beans and its significance for root geotropism. Planta 128:59-62.

Hartung, W. 1983. The site of action of abscisic acid at the guard cell plasmalemma of Valerianella locusta. Plant Cell Environ. 6:427-428.

Heino, P., G. Sandman, V. Lang, K. Nordin, and E.T. Palva. 1990. Abscisicacid deficiency prevents development of freezing tolerance in Arabidopsis thaliena (L.) Heynh. Theor. Appl. Genet. 79:801-806.

Hightower, R., C. Raden, E. Penses, P. Lund, and P. Dunsmuir. 1991. Expression of antifreeze proteins in transgenic plants. Plant Mol. Biol. 17:10131021 .

Hincha, D.K., V. Heber, and J.M. Schmitt. 1990. Proteins from frost-hardy leaves protect thylaboids against freeze-thaw damage in vitro. Planta 180:416-419.

Hirsh, A.G. 1987. Vitrification in plants as a natural form of cryoprotection. Cryobiology 24:214-228.

Houde, M., J. Danyluk, J.F. Laliberté, E. Rassart, R. Dhindsa, and F. Sarhan. 1992. Cloning, characterization and expression of a cDNA encoding a 50 kD protein specifically induced by cold acclimation. Plant Physiol. 99:13811387.

Jarillo, J.A., A.L. Leyva, J. Salinas, and J.M. Martinez-Zapater. 1993. Low temperature induces the accumulation of alcohol dehydrogenase mRNA in Arabidopsis thaliana, a chilling-tolerant plant. Plant Physiol. 101:833-837.

Jinn, T.L., Y.C. Yeh, Y.M. Chen, and C.Y. Lin. 1989. Stabilization of soluble proteins in vitro by heat shocks protein-enriched ammonium sulfate fraction from soybean seedlings. Plant Cell Physiol. 30:463-469.

John, O-A. and S. Yamaki. 1994. Sugar content, compartmentation, and efflux in strawberry tissue. J. Amer. Soc. Hort. Sci. 119:1024-1028.

Johnson-Flanagan, A.M., Z. Huiwer, M.R. Thiogaraja, and H.S. Saini. 1991. Role of abscisic acid in the induction of freezing tolerance in Brassica napus suspension-cultured cells. Plant Physiol. 95:1044-1048.

Jones, R.J. and T.A. Mansfield. 1971. Effect of abscisic acid and its esters on stomatal aperture and the transpiration ratio. Physiol. Plant. 26:321-327.

Keith, C.N. and B.D. McKerzie. 1986. The effect of abscisic acid on the freezing tolerance of callus cultivars of Lotus corniculatus L. Plant Physiol. 80:766-770.

Kimpel, J.A. and J.L. Key. 1985. Presence of heat shock mRNAs in field grown soybeans. Plant Physiol. 79:672-678.

Kononowicz, A.J., K.G. Raghothama, A.M. Casas, M. Reuveri, A-EA Watad, D. Liu, R.A. Bressan, and P.M. Hasagawa. 1993. Osmotin: Regulation of expression and function, p. 144-158. In: T.J. Close andE.A. Bray (eds.). Plant responses to cellular dehydration during environmental stress. Current topics in plant physiology. vol. 10. Amer. Soc. Plant Physiol., Rockville, Md.

Koster, K.L. 1991. Glass formation and desiccation tolerance in seeds. Plant Physiol. 96:302-304

Lang, V., P. Heino, and E.T. Palva. 1989. Low temperature acclimation and treatment with exogenous abscisic acid induce common polypeptides in Arabidopsis thaliana (L.) Heynh. Theor. Appl. Genet. 77:729-734.

Lang, V. and E.T. Palva. 1992. The expression of a rab-related gene rab18 is induced by abscisic acid during the cold acclimation process of Arabidopsis thaliana (L) Heynh. Plant Mol. Biol. 20:951-962.

Levitt, J. 1980. Response of plants to environmental stress, chilling, freezing and high temperatures. 2nd ed. vol. 1. Academic, New York.

Lin, C. and M.F. Thomashow. 1992. A cold-regulated Arabidopsis gene encodes a polypeptide having potent cryoprotective activity. Biochem. Biophys. Res. Communications 183:1103-1108.

Machackova, I., A. Hanisova, and J. Krekule. 1989. Levels of ethylene, ACC, MACC, ABA and proline as indicators of cold hardening and frost resistance in winter wheat. Physiol. Plant. 76:603-607.

MacHutchon, M.G. 1991. Developmental biology of cold acclimation in winter cereals. PhD Diss., Univ. of Saskatchewan, Saskatoon, Canada.

MacHutchon, M.G., W.L. Downing, J.C. McPherson, K. Kenward, and P.L. Davies. 1991. Freezing tolerance of transgenic tobacco, p. 13. In: Fifth International Conference on Biological Ice Nucleation, Madison, Wis., 4 7 Aug. 1991.

Markhart, A.H. 1982. Penetration of soybean root systems by abscisic acid isomers. Plant Physiol. 69:1350-1352.
Mason, H.S. and J.E. Mullet. 1990. Expression of two soybean vegetative storage protein genes during development and in response to water deficit, wounding and jasmonic acid. Plant Cell 2:569-579.

Matsuda, Y., T. Okuda, and S. Sagisaka. 1994. Differences in activities related to cessation of synthesis of inducible proteins as an early response to cold between hardy and less hardy cultivars of winter wheat. Biosci. Biotech. Biochem. 58:32-37.

McKersie, B.D., Y. Chen, M. de Beus, S.R. Bowley, C. Bowler, D. Inze, K.D. D'Halluin, and J. Botterman. 1993. Superoxide dismutase enhances tolerance of freezing stress in transgenic alfalfa (Medicago sativa L.). Plant Physiol. 103:1155-1163.

Milborrow, B.V. 1978. Abscisic acid, p. 295-347. In: D.S. Letham (ed.). Phytohormones and related compounds: A comprehensive treatise. vol. 1. Elsevier, Amsterdam.

Milborrow, B.V. and M. Garmston. 1973. Formation of (-)-1',2'-epi-2-cisxanthoxin acid from a methylpenta-cis-2-trans-4-dienoic acid into abscisic acid in plants. Biochem. J. 119:727-736

Morrison, J.J. and C.J. Andrews. 1992. Variable increases in cold hardiness induced in winter rape by plant growth regulators. J. Plant Growth Regulat. 11:113-117.

Nolan, R.C. and T.T.D. Ho. 1988. Hormonal regulation of $\alpha$-amylase expression in barley aleurone layers. Plant Physiol. 88:488-593.

Nordin, K., P. Heino, and E.T. Palva. 1991. Separate signal pathways regulate the expression of a low-temperature-induced gene in Arabidopsis thaliana (L) Heyhn. Plant Mol. Biol. 16:1061-1071.

Norman, S.M., R.D. Bennett, S.M. Poling, V.P. Maier, and M.D. Nelson. 1986. Paclobutrazol inhibits abscisic acid biosynthesis in Cercospora rosicola. Plant Physiol. 80:122-125.

Olien, C.R. 1967. Freezing stresses and survival. Annu. Rev. Plant Physiol. $18: 387-408$.

Orr, W., W.A. Keller, and J. Singh. 1986. Induction of freezing tolerance in an embryogenic cell suspension culture of Brassica napus by abscisic acid at room temperature. J. Plant Physiol. 126:23-32.

Orr, W., J. Singh, and D.C.W. Brown. 1985. Induction of freezing tolerance in alfalfa cell suspension cultures. Plant Cell Rpt. 4:15-18.

Parthier, B. 1990. Jasmonates: Hormonal regulators or stress factors in leaf senescence? J. Plant Growth Regulat. 9:57-63.

Pennypacker, B.W., P.L. Sanders, L. Vaun Gregory, E.P. Gilridge, and H. Cole 1982. Influence of triadimefon on the foliar growth and flowering of annual bluegrass. Can. J. Pathol. 4:259-262.

Reaney, M.J.T. 1989. Factors affecting abscisic acid induced freezing resistance in cell suspension cultures. PhD Diss., Univ. of Saskatchewan, Saskatoon, Canada.

Reaney, M.J.T. and L.V. Gusta. 1987. Factors influencing the induction of freezing tolerance by abscisic acid in cell suspension cultures of Bromus inermis Leyss and Medicago sativa L. Plant Physiol. 83:423-427.

Reaney, M.J.T. and L.V. Gusta. 1994. The unnatural analog of ABA in racemic ABA is an inhibitor of phaseic acid dehydrogenase activity of bromegrass cell suspension cultures. Plant Physiol. 105S:19.

Reaney, M.J.T., L.V. Gusta, S.R. Abrams, and A.J. Robertson. 1989. The effects of abscisic acid, kinetin and gibberellins on freezing tolerance in smooth bromegrass (Bromus inermis) cell suspension. Can. J. Bot. 67:3640 3646.

Reinbothe, S., A. Machmudova, C. Wasteanack, C. Reinbothe, and B. Parthier. 1992a. Jasmonate-induced proteins in cotton: Immunological relationship to the respective barley proteins and homology of transcripts to late embryogenesis abundant (Lea) in mRNAs. J. Plant Growth Regulat. 11:714

Reinbothe, S., C.C. Reinbothe, J. Lehmann, and B. Parthier. 1992b. Differential accumulation of induced mRNAs in response to abscisic acid and desiccation in barley (Hordeum vulgare). Physiol. Plant. 86:49-56.

Robertson, A.J., G.C. Churchill, and L.V. Gusta. 1993. The role of plant growth regulators on the freezing tolerance of winter annual cereals and cell suspension cultures, p. 273-283. In: P.H. Li and L. Christensson (eds.). Advances in plant cold hardiness. CRC Press, Boca Raton, Fla.

Robertson, A.J., M. Ishikawa, L.V. Gusta, and S.L. MacKenzie. 1994a. Abscisic acid-induced heat tolerance in Bromus inermis Leyss cellsuspension cultures. Heat-stable, abscisic acid-responsive polypeptides in combination with sucrose confer enhanced thermastability. Plant Physiol. 105:181-190.

Robertson, A.J., M.J.T. Reaney, R.W. Wilen, N. Lamb, S.R. Abrams, and L.V. Gusta. 1994b. Effects of abscisic acid metabolites and analogs on freezing tolerance and gene expression in bromegrass (Bromus inermis) cell cultures. Plant Physiol. 105:823-830.

Robertson, A.J., A. Weninger, R.W. Wilen, P. Fu, and L.V. Gusta. 1994c. Comparison of dehydrin gene expression and freezing tolerance in Bromus inermis and Secales cereale grown in controlled environments, hydroponics, and in the field. Plant Physiol. 106:1213-1216.

Russell, D.A. and M.A. Sachs. 1989. Differential expression and sequence 
analysis of the maize glyceraldehyde-3-phosphate dehydrogenase gene family. Plant Cell 1:793-803.

Sakai, A. 1962. Studies on the frost hardiness of woody plants. I. The causal relationship between sugar content and frost hardiness. Inst. Low Temp. Sci. B11:1-40.

Sakai, A. 1966. Seasonal variations in the amounts of polyhydric alcohol and sugar in fruit trees. J. Hort. Sci. 41:207-213.

Sakai, A. and Y. Sugawara. 1973. Survival of poplar callus at super-low temperature after cold acclimation. Plant Cell Physiol. 14:1201-1204.

Schmütz, W. 1978. Vernalization requirements of winter barley varieties. Barley Genet. Nwsltr. 8:82-86.

Sembdner, G. and D. Gross. 1986. Plant growth substances of plant and microbial origin, p. 139-147. In: M. Bopp (ed.). Plant growth substances 1985. Springer-Verlag, Berlin.

Sembdner, G. and B. Parthier. 1993. The biochemistry and the physiological and molecular actions of jasmonates. Annu. Rev. Plant Physiol. Plant Mol. Biol. 44:569-589.

Sen Gupta, A., J.L. Heinen, A.S. Holaday, J.J. Burke, and R.D. Allen. 1993. Increased resistance to oxidative stress in transgenic plants that overexpress chloroplastic $\mathrm{Cu} / \mathrm{Zn}$ superoxide dismutase. Proc. Natl. Acad. Sci. USA 90:1629-1633.

Shindy, W.W., C.M. Asmundson, O.E. Smith, and J. Kumamoto. 1973. Absorption and distribution of high specific radioactivity $2-{ }^{14} \mathrm{C}$-abscisic acid in cotton seedlings. Plant Physiol. 52:443-447.

Smith, D. 1968. Carbohydrates in grasses. IV. Influence of temperature on the sugar and fructosan composition of timothy (Phleum pratense) plant parts at anthesis. Crop Sci. 8:331-334.

Smithberg, M.H. and C.J. Weiser. 1968. Patterns of variation among climatic races of red-osier dogwood. Ecology 49:495-505.

Staswick, P.E., W. Su, and S.H. Howell. 1992. Methyl jasmonate inhibition of root growth and induction of a leaf protein are decreased in an Arabidopsis thaliana mutant. Proc. Natl. Acad. Sci. USA 89:6837-6840.

Taylor, J.S., M.K. Bhalla, J.M. Robertson, and L.J. Piening. 1990. Cytokinins and abscisic acid in hardening winter wheat. Can. J. Bot. 68:1597-1601.

Vierling, E. 1991. The roles of heat shock proteins in plants. Annu. Rev. Plant Physiol. Plant Mol. Biol. 42:579-620.

Volger, H.G. and V. Heber. 1975. Cryoprotective leaf proteins. Biochem. Biophys. Acta 412:335-349.

Wallenstein, A. and L.S. Albert. 1963. Plant morphology: Its control in Proserpinaca by photoperiod, temperature and gibberellic acid. Science 140:998-1000.

Walton, D.C. 1983. Structure-activity relationships of abscisic acid analogs and metabolites, p. 113-146. In: F.T. Addicot (ed.). Abscisic acid. Praeger Scientific, New York.

Weiser, C.J. 1970. Cold resistance and injury in woody plants. Science 169:1269-1278.

Weretilnyk, E., W. Orr, T.C. White, B. Tu, and J. Singh. 1993. Characterization of three related low temperature-regulated cDNAs from winter Brassica napus. Plant Physiol. 101:171-177.

Whitaker, B.C. and C.Y. Wang. 1987. Effect of paclobutrazole and chilling on leaf membranes in cucumber seedlings. Physiol. Plant. 70:404-411.

Wilen, R.W., B.E. Ewan, and L.V. Gusta. 1994a. Interaction of abscisic acid and jasmonic acid on the inhibition of seed germination and the induction of freezing tolerance 1994. Can. J. Bot. 72:1009-1017.

Wilen, R.W., L.V. Gusta, P. Fu, A.J. Robertson, S.R. Abrams, and N.H. Low. 1994b. The roles of ABA, carbohydrates and heat-stable proteins in freezing tolerance in bromegrass. Plant Physiol. 94:48.

Wilen, R.W., L.V. Gusta, B. Lei, S.R. Abrams, and B.E. Ewan. 1994c. Effects of abscisic acid (ABA), and ABA analogs or freezing tolerance, low temperature growth, and flowering in rapeseed. J. Plant Growth Regulat. 13:235-241.

Wilen, R.W., D.B. Hays, R.M. Mandel, S.R. Abrams, and M.M. Moloney. 1993. Competitive inhibition of ABA-regulated gene expression by steroisomeric acetylenic analogs of abscisic acid. Plant Physiol. 10:469-476.

Wilen, R.W., A.J. Robertson, P. Fu, and L.V. Gusta. 1994d. The molecular biology of cold acclimation, p. 291-325. In: S.S. Purohet (ed.). Agro annual review of plant physiology (basic \& applied). Agro Botanical, New Delhi, India.

Wilen, R.W., G.J.H. van Rooijen, D.W. Pearce, R.P. Pharis, L.A. Holbrook, and M.M. Moloney. 1991. Effects of jasmonic acid on embryo-specific processes in Brassica and Linium oilseeds. Plant Physiol. 95:399-405.

Willenoës, J.G., J. Beltrano, and E.R. Montaldi. 1988. Diagravitropic growth promoted by high sucrose contents in Paspalum vaginatum and its reversion by gibberellic acid. Can. J. Bot. 66:2035-2037.

Wolfraim, L.A., R. Langis, H. Tyson, and R.S. Dhindsa. 1993. cDNA sequence, expression and transcript stability of a cold acclimation-specific gene, cas 18, of alfalfa (Medicago falcata) cells. Plant Physiol. 101:12751282.

Zeevaart, J.A.D. and R.A. Creelman. 1988. Metabolism and physiology of abscisic acid. Annu. Rev. Plant Physiol. Plant Mol. Biol. 39:439-473.

Zeevaart, J.A.D., D.A. Gage, and R.A. Creelman. 1990. Recent studies of the metabolism of abscisic acid, p. 233-240. In: R.P. Pharis and S.B. Rood (eds.). Plant growth substances 1988. 13th Intl. Conf. on Plant Growth Substances, Calgary, Alberta, Canada. Springer-Verlag, Berlin. 


\title{
Theory and Application of Genetic Engineering for Stress Resistance and Avoidance
}

\author{
Steven E. Lindow \\ Department of Environmental Science, Policy, and Management, 108 Hilgard Hall, University of California, \\ Berkeley, CA 94720-3110
}

Recent technical advances in the manipulation of plants and microorganisms make it possible to alter them in many innovative ways to confer resistance or tolerance to biological and abiotic stresses. The majority of stress-resistance research relates to practical applications of plant genetic engineering, although some research also has been directed to the application of recombinant DNA techniques to stress-inducing microorganisms, particularly as it relates to biological control of plant disease and frost injury. Because of the vast scope of plant molecular biology and molecular studies of plant-associated microorganisms, this review will not address all of the technological advances or possible applications of molecular studies that are related to stress resistance and avoidance. Instead, this review will provide an overview of the general areas of research relating to stress resistance; major areas of research will be highlighted with specific studies of particular scientific or practical merit. The focus of most of the examples to be discussed will relate to resistance of plants to biotic stresses, as well as to abiotic stresses that are conferred by biotic agents, such as ice nucleation active bacteria. Little attention will be placed on other abiotic stresses, such as salt stress, etc. A broad overview of the extent of field activities using modified plants and plant-associated microbes also will be provided.

\section{STRESS RESISTANCE}

\section{Disease resistance genes}

Plant diseases are a major source of stress for nearly all agricultural plants. While chemical pesticides must be used in many cases to control fungal and bacterial pathogens, genetic disease resistance has always been a more efficacious and cost-effective method of disease control (Keen, 1992). In this approach, genes conferring disease resistance are identified in wild variants of the crop species or in wild species relatives of the crop plant and introgressed by sexual crosses. In many cases, the sources of disease resistance are limited either because they are absent from the gene pool or because wild plant relatives that are the source of the gene(s) have become extinct because of land-use changes. Even when disease resistance is present in wild plant relatives, there are limitations to its introduction to crop plants because these plants must be capable of gene exchange. For this reason, a long-term goal in plant disease-resistance management has been to clone disease-resistance genes so that they can be more easily deployed (Innes et al., 1993; Keen, 1992; Lamb, 1994; Mansky and Hill, 1993).

Within the last few years, several plant disease resistance genes that confer resistance to bacterial and fungal pathogens have been cloned (Bent et al., 1994; Johal and Briggs, 1992; Martin et al., 1993; Mindrinos et al., 1994; Moffat, 1994; Whitham et al., 1994). Curiously, these resistance genes, although conferring resistance to various types of plant pathogens, have many structural similarities, which suggest that it might be possible to identify other resistance genes based on their conserved genetic structure (Moffat, 1994). The physical isolation of these disease resistance genes should make it possible to introduce them into heterologous hosts that are not capable of sexual crosses with the host plants from which they were isolated, and to

Received for publication 25 May 1995. Accepted for publication 24 July 1995. The cost of publishing this paper was defrayed in part by the payment of page charges. Under postal regulations, this paper therefore must be hereby marked advertisement solely to indicate this fact. pyramid allelic resistance genes. Cloning disease resistance genes remains a highly active area of research and promises to be very fruitful in advancing this strategy of disease control.

\section{Pathogen-derived resistance}

Virus disease resistance. Novel sources of plant disease resistance, termed "pathogen-derived resistance" (Sanford and Johnston, 1985), can be attained by introducing certain genes from plant pathogens into their host plants. The concept of pathogen-derived resistance is most developed in the case of plant virus diseases. Seminal studies by Beachy and coworkers (Powell-Abel et al., 1986) demonstrated that the introduction of viral genes conferring the production of the coat protein from tobacco mosaic virus (TMV) into tobacco (Nicotiana tabacum L.) plants greatly reduced the incidence of infection and delayed symptom development when those plants were challenged with TMV. While these initial studies showed this approach to be highly effective in inhibiting infection of tobacco by TMV, we now know that coat protein genes confer resistance to a wide range of viruses when introduced into their homologous host plants (Fitchen and Beachy, 1993; Gonsalves and Slightom, 1993; Hayakawa et al., 1992; Lindbo et al., 1993; Nejidat and Beachy, 1990; RheimannPhilipp and Beachy, 1993; Scholthof et al., 1993; Wisniewski et al., 1990). More recent work has shown evidence, or has provided promising leads, that many differing viral gene products, when introduced into plants, may interfere with viral infection of plants. For example, antisense RNA can interfere with translation of viral RNA sequences upon introduction into plants and interrupt RNA viral replication (Fitchen and Beachy, 1993; Scholthof et al., 1993). Defective viral replicases, proteases, transmission factors, and movement proteins can interfere with vital steps in processing viral proteins within plant cells, with their acquisition by insect vectors, and with cell-to-cell movement required for spread of the virus from initially infected cells (Anderson et al., 1992; Fitchen and Beachy, 1993; Longstaff et al., 1993; Scholthof et al., 1993; Zaitlin et al., 1994).

Transgenic plants containing viral genes, particularly coat protein genes, exhibit greatly reduced susceptibility to virus infection but incomplete disease resistance (Fitchen and Beachy, 1993). Depending on the particular transgenic plant-viral system investigated, disease control is frequently in excess of $85 \%$ (Fitchen and Beachy, 1993; Gonsalves and Slightom, 1993; Jongedijk et al., 1993). Because most mechanisms of disease resistance that have been suggested for this type of pathogen-derived resistance involve the competition of viral products produced within transgenic plants with the intact virus upon its entry into a cell (Fitchen and Beachy, 1993), a strong "titration effect" usually is seen. While, for example, some viral particles are capable of uncoating and initiating translation upon entry into plant cells containing an abundance of viral coat protein, due to stable integration of a viral coat protein gene (transgene) into the plant genome, severe competition with endogenous coat protein causes most particles not to uncoat when the transgene confers high levels of production of the coat protein. Thus, transgenes normally have to be expressed at relatively high levels to confer large effects on the viral life cycle.

Disease resistance conferred by the introduction of viral genes is frequently restricted to inhibiting infection only of the virus from which the transgene was derived, or closely related strains (Fitchen and Beachy, 1993). However, in some cases, related viral groups with similar replication strategies, etc., also can be controlled (Lindbo et al., 1993; Nejidat and Beachy, 1990). Because of the massive interruption of the viral life cycle in transgenic plants containing particular viral 
transgenes, there is a strong selection for viral mutants that are less efficiently inhibited. Viral mutants that greatly differ in their ability to be controlled in transgenic plants have been found in laboratory studies (Schoelz and Wintermantel, 1993). Whether this propensity for viral mutation to overcome pathogen-derived resistance will be seen in the field has yet to be determined. Several scientists also have raised concerns that introducing viral genes into plants could enable viral recombination to occur under field conditions (Chasan, 1993; Farinelli et al., 1992; Schoelz and Wintermantel, 1993; Tepfer, 1993). Theoretically, such recombination could increase the genetic diversity of viral plant pathogens and increases disease risk. This concern is being widely discussed in the current scientific literature, and research that addresses the likelihood of viral recombination in transgenic plants and the significance of such recombination will probably remain an active area of research for some time to come.

Toxin resistance. Several bacterial and fungal plant pathogens increase their virulence by producing host-specific or nonspecific toxins. Since pathogens are resistant to the toxins that they produce, the disease symptoms caused by some of these pathogens can be restricted by introducing pathogen genes involved in toxin resistance into plants. The best example of pathogen-derived resistance to toxin-mediated disease is the case of halo blight disease of bean (Phaseolus vulgaris L.) caused by the bacterium Pseudomonas syringae pv. phaseolicola. The extensive chlorosis of plants infected by $P$. syringae pv. phaseolicola is induced by phaseolotoxin, a tripeptide toxin (Mitchell, 1976; Staskawicz et al., 1980). Phaseolotoxin inhibits the enzyme ornithine carbamoyltransferase (OCTase), which converts ornithine and carbamoyl phosphate to citrulline, a reaction involved in the biosynthesis of arginine and in the interconversion of the glutamate family of amino acids (Mitchell, 1976; Staskawicz et al., 1980). Phaseolotoxin also inhibits the growth of many bacteria, since they also contain OCTase activity. Pseudomonas syringae pv. phaseolicola produces two OCTases, one sensitive and one resistant to phaseolotoxin (Staskawicz et al., 1980). During growth under cool conditions when phaseolotoxin biosynthesis is optimum, this pathogen produces the resistant OCTase exclusively, which thus confers resistance to its own toxin (Hatziloukas and Panopoulos, 1992; Staskawicz et al., 1980). The phaseolotoxin-insensitive OCTase of $P$. syringae pv.phaseolicola has been cloned and introduced into plants (de la Fuente-Martinez et al., 1992; Hatziloukas and Panopoulos, 1992; Mosqueda et al., 1990). Plants produce this phaseolotoxin-insensitive OCTase in addition to their indigenous OCTase, which is sensitive to phaseolotoxin (Hatziloukas and Panopoulos, 1992). The presence of the toxininsensitive OCTase in plants, however, enables them to bypass the enzymatic blockage that would otherwise be conferred when the bacterium produces phaseolotoxin inside the plant. Therefore, such plants likely would be insensitive to the toxin and thus exhibit fewer disease symptoms than normal plants.

\section{Abiotic stress resistance}

The freezing tolerance of frost-hardy plant species potentially can be improved by altering the freezing process in the plants. Frost-hardy plant species are distinguished from frost-sensitive species in that they have evolved numerous mechanisms to allow them to tolerate ice formation within their tissues (Burke et al., 1976). An important requirement of frost tolerance in hardy species is the slow movement of water out of plant cells to freeze intercellularly in equilibrium with the water potential of the intercellular ice (Burke et al., 1976). When the water potential within and outside of the plant cells can be maintained at near equilibrium by slow dehydration of the cells during cooling, and if the plant has other mechanisms to allow it to tolerate the cell dehydration which results from intercellular ice formation, the plant can tolerate freezing (Burke et al., 1976; Chandler, 1958). Studies have shown, however, that supercooling plant tissues before ice formation occurs is deleterious to this process (Rajashekar et al., 1983). For example, water apparently cannot move out of supercooled plant cells sufficiently rapidly when supercooled intercellular water is nucleated; ice can then penetrate into the plant cells (Rajeshekar et al., 1983). Therefore, if ice formation occurred at higher temperatures in plants in the presence of efficient nucleating agents, plants would be assured of attaining their hardiness potential (Rajeshekar et al., 1983). Several species of plant-associated bacteria have the potential to catalyze ice formation at temperatures as high as $-2 \mathrm{C}$ (Lindow, 1983a; Lindow et al., 1978b; Maki et al., 1974). Pseudomonas syringae is the most commonly observed ice-nucleation-active $\left(\right.$ Ice $\left.^{+}\right)$bacterium, and the one most active in ice nucleation. The genetic determinants of bacterial ice nucleation have been described in most $\mathrm{Ice}^{+}$bacterial species (Warren, 1987; Warren and Wolber, 1991). In all cases, a single gene conferring production of a large protein confers production of bacterial ice nuclei (Wolber, 1992; Wolber and Warren, 1989). Bacterial ice nucleation proteins all appear to be composed of a unique tandem repetition of a similar 48-amino-acid motif (Gurian-Sherman and Lindow, 1993; Warren and Corotto, 1989; Wolber and Warren, 1989). This repetitive structure appears to produce a protein surface with hydrogen bonding groups sufficiently similar in spatial orientation to the hydrogen bonding groups on an ice crystal to orient water molecules into an ice-like embryo (Kajava and Lindow, 1993). The monogenic nature of bacterial ice nucleation determinants facilitate its introduction into other species.

The ice nucleation gene from $P$. syringae has been introduced into several plant species. Both tobacco, a frost-sensitive species, and Solanum commersonii Dun. PI458317, a frost-tolerant species, exhibit enhanced ice nucleation activity when the ice nucleation gene from $P$. syringae was introduced via Agrobacterium-mediated transformation (Baertlein et al., 1992). The number of ice nuclei per gram of plant tissue was increased dramatically at all temperatures above about -10C (Baertlein et al., 1992). Most importantly, the threshold nucleation temperature of both plant species increased from about $-7 \mathrm{C}$ to about $-3 \mathrm{C}$ when the bacterial ice nucleation gene was introduced. While further increases in the threshold ice nucleation temperature (to at least $-2 \mathrm{C}$ ) will be required to attain maximum increases in frost resistance by avoiding supercooling (Baertlein et al., 1992; Rajashekar et al., 1983), this strategy of increasing frost tolerance by raising the threshold nucleation temperature of plants seems feasible. Potentially, many frost-tolerant plant species could benefit from the introduction of bacterial ice nucleation genes.

\section{STRESS AVOIDANCE}

The best example of genetic manipulations that confer stress avoidance relate to the control of frost damage in frost-sensitive plant species. Sensitive plant species have little or no ability to tolerate ice formation within their tissues. Whenever ice formation occurs, it spreads rapidly, both intercellularly and into plant cells, causing mechanical damage (Burke et al., 1976; Cary and Mayland, 1970; Chandler, 1958). Ice formation in such plants is, therefore, inevitably damaging. Frost-insensitive plant species have the ability to supercool and avoid damaging ice formation (Cary and Mayland, 1970; Modlibowska, 1962). Under many conditions in the natural environment, however, the supercooling potential of these frost-sensitive species is limited by the occurrence of Ice ${ }^{+}$bacteria. While leaves and flowers of many frost-sensitive plants can readily supercool to $-5 \mathrm{C}$ or colder when grown in the absence of ice-nucleation-active bacteria (Lindow et al., 1978a, 1982), large population sizes of Ice ${ }^{+}$bacteria initiate ice formation and thus induce frost damage at temperatures as high as -2C (Hirano et al., 1985; Lindow, 1982; Lindow et al., 1982). $\mathrm{Ice}^{+}$bacteria, therefore, are incitants of frost damage to many frostsensitive plants. Reducing the population size of Ice $^{+}$bacteria can reduce the likelihood of damaging ice formation (Lindemann and Suslow, 1987; Lindow, 1982, 1983a; 1983b). While chemical control of Ice ${ }^{+}$bacteria has been achieved by frequent application of bactericides, such as copper-containing compounds (Lindow, 1983a, 1983b; Lindow and Connell, 1984), this approach is costly to implement for many plant species because the plants are growing rapidly at the time freezing temperatures are encountered and frequent applications of the bactericide are therefore required. The application of non-ice-nucleation-active bacteria at the proper time, however, can lead to prolonged colonization of plant surfaces and the competitive exclusion of Ice $^{+}$bacteria (Lindow, 1983b, 1987; Lindow et al., 1983a, 1983b). In this approach, non-ice-nucleation-active bacteria are applied to developing plant parts before they are colonized by Ice ${ }^{+}$bacteria and other 
bacterial species (Lindow, 1985a). When applied to such a "biological vacuum," non-ice-nucleation-active bacteria can grow rapidly and use nutrient resources, which apparently limits the growth of microorganisms on plant surfaces (Lindow, 1985a). Biological control of frost damage by applying non-ice-nucleation-active bacteria, therefore, is a form of preemptive competitive exclusion of the Ice ${ }^{+}$bacteria.

Cloning bacterial ice nucleation genes has made it possible to construct non-ice-nucleation-active $\left(\mathrm{Ice}^{-}\right)$derivatives of several Ice ${ }^{+}$ bacterial species for use as biological control agents of frost damage. Deletion-containing ice-nucleation genes were produced in vitro by removing defined restriction fragments from the internal portion of cloned ice nucleation genes (Lindow, 1985b; Orser et al., 1985). Functional chromosomal ice nucleation genes in Ice $^{+}$strains were replaced by nonfunctional deletion-containing genes produced in vitro by a process of marker-exchange mutagenesis (Ruvkun and Ausubel, 1981). In this process, deletion-containing ice-nucleation genes are cloned into plasmid vectors that cannot be maintained within icenucleating species, such as $P$. syringae. After introduction into this species by conjugation or electroporation, the deletion-containing genes were "rescued" from the plasmid into the chromosome by homologous recombination because of the occurrence of identical sequences in other parts of the plasmid-borne gene and the chromosomal gene. The process of marker-exchange mutagenesis does not result in the introduction of novel genetic material into the bacterial strain; instead, it is a form of site-directed mutagenesis of this deleterious locus.

Recombinant Ice ${ }^{-}$mutants of $P$. syringae have phenotypes that make them attractive for use in the preemptive competitive exclusion of Ice ${ }^{+}$strains under field conditions. Recombinant Ice ${ }^{-}$strains exhibited no observable phenotypic differences (aside from the abolition of the ice nucleation phenotype) compared to the parental strain (Lindow, $1985 b, 1990)$. For example, such strains had wild-type growth rates on plants and did not differ from parental strains in their host preference among a wide range of plant species tested for epiphytic colonization (Lindemann and Suslow, 1987; Lindow, 1985b).

Field tests of recombinant Ice ${ }^{-}$mutants of $P$. syringae reveal that they have substantial utility in the biological control of frost damage to potato (Solanum tuberosum L.) under field conditions. Ice ${ }^{-} P$. syringae strains behaved under field conditions in a manner similar to that predicted from preliminary greenhouse and growth chamber studies (Lindow, 1990; Lindow and Panopoulos, 1988). For example, Ice $^{-} P$. syringae strains achieved high populations (in excess of $10^{6}$ cells per gram fresh weight) on potato plants for up to 1 month following their spray inoculation onto the leaves of potato plants that had recently emerged from soil (Lindow and Panopoulos, 1988). In contrast, the Ice ${ }^{-}$mutants did not survive in the soil, which was inoculated during the spray treatment of potato plants (Lindow and Panopoulos, 1988). There also was no measurable colonization of plants outside of the plot area by Ice ${ }^{-}$mutants that were dispersed during spray inoculation (Lindow and Panopoulos, 1988). The incidence of frost damage to treated potato plants during natural radiative frosts (having air minima of about $-4 \mathrm{C}$ ) was about $25 \%$ that of nontreated control plants during trials that were initiated in 1987 (Lindow, 1990). Thus, the strategy by which deleterious traits are removed from plant-associated bacteria to produce useful biological control agents appears sound. An analogous strategy, by which virulence genes can be disrupted in plant pathogenic bacteria, also shows promise for producing biological control agents of plant diseases. Clearly, this approach will benefit from further molecular biological investigations of deleterious plant-associated bacteria.

\section{FIELD TESTING RECOMBINANT PLANTS AND MICROORGANISMS}

While hundreds of tests of transgenic plants with various alterations have taken place recently, the number of recombinant microorganisms that have been field-tested remain low. As of 1992, field tests had been conducted with 31 plant species in 28 countries (Goy et al., 1994) As of that time, 675 field trials of transgenic plants had been completed or were underway. The number of field trials of transgenic plants has increased dramatically with time, to a total of 244 in 1992 , since the first five tests were conducted in 1986 (Goy et al., 1994). In contrast, since the release of the first two recombinant Ice ${ }^{-}$strains of P. syringae for the biological control of frost injury in 1987, a total of only 27 tests involving recombinant microorganisms have been conducted (Wilson and Lindow, 1993). Not unexpectedly, the most commonly tested plant species were important crop species, including corn (Zea mays L.), tomato (Lycopersicon esculentum Mill.), tobacco, and potato (Goy et al., 1994). A high percentage of field tests of transgenic plants have been conducted by companies as opposed to public research institutions (501 vs. 156). Not unexpectedly, field tests conducted by companies have focused almost exclusively on major crop plants, including corn, tomato, and tobacco. In contrast, a much greater diversity of plant species are under investigation by researchers in public institutions. Commonly, these transgenic plants are modified by introducing pathogen-derived genes (most commonly viral coat protein genes) into locally important crop plants. A high percentage of field tests of transgenic plants by corporate sponsors, in contrast, involves testing herbicide resistance and certain product quality improvements, such as genes determining delayed fruit ripening in tomato (Goy et al., 1994).

Little public resistance has arisen to field testing transgenic plant species. However, the considerable regulatory hurdles facing most applicants wishing to perform field tests of recombinant microbial species has probably reduced the research activity in this arena. Because of the large number and rich array of transgenic plants that have been and will be tested in the near future, we can anticipate exciting, effective, and environmentally friendly solutions to plant stress problems in the future.

\section{Literature Cited}

Anderson, J.M., P. Palukaitis, and M. Zaitlin. 1992. A defective replicase gene induces resistance to cucumber mosaic virus in transgenic tobacco plants. Proc. Natl. Acad. Sci. USA 89:8759-8763.

Baertlein, D.A., S.E. Lindow, N.J. Panopoulos, S.P. Lee, M.N. Mindrinos, and T.H. Chen. 1992. Expression of a bacterial ice nucleation gene in plants. Plant Physiol. 100:1730-1736.

Bent, A.F., B.N. Kunkel, D. Dahlbeck, K.L. Brown, R. Schmidt, J. Giraudat, J. Leung, and B.J. Staskawicz. 1994. RPS2 of Arabidopsis thaliana: A leucine-rich repeat class of plant disease resistance genes. Science 265:18561860.

Burke, M.J., L.A. Gusta, H.A. Quamme, C.J. Weiser, and P.H. Li. 1976. Freezing and injury to plants. Annu. Rev. Plant Physiol. 27:507-528.

Cary, J.W. and H.F. Mayland. 1970. Factors influencing freezing of supercooled water in tender plants. Agron. J. 62:715-719.

Chandler, W.H. 1958. Cold resistance in horticultural plants: A review. Proc. Amer. Soc. Hort. Sci. 64:552-572.

Chasan, R. 1993. Harvesting virus recombinants. Plant Cell 5:1489-1491.

de la Fuente-Martinez, J.M., G. Mosqueda-Cano, A. Alvarez-Morales, and L. Herrera-Estrella. 1992. Expression of a bacterial phaseolotoxin-resistant ornithyl transcarbamylase in transgenic tobacco confers resistance to Pseudomonas syringae pv. phaseolicola. Bio/Technology 10:905-909.

Farinelli, L., P. Malnoe, and G.E. Collet. 1992. Heterologous encapsidation of potato virus $\mathrm{Y}$ strain $\mathrm{O}\left(\mathrm{PVY}^{\circ}\right)$ with the transgenic coat protein of $\mathrm{PVY}$ strain N $\left(\mathrm{PVY}^{\mathrm{n}}\right)$ in Solanum tuberosumcv. Bintje. Bio/Technology 10:10201025 .

Fitchen, J.H., and R.N. Beachy. 1993. Genetically engineered protection against viruses in transgenic plants. Ann. Rev. Microbiol. 47:739-763.

Gonsalves, D. and J.L. Slightom 1993. Coat protein-mediated protection: Analysis of transgenic plants for resistance in a variety of crops. Seminars Virol. 4:397-405.

Goy, P.A., E. Chasseray, and J. Duesing. 1994. Field trials of transgenic plants: An overview. Agro-Food-Industry Hi-Tech 5:10-15.

Gurian-Sherman, D. and S.E. Lindow. 1993. Bacterial ice nucleation: Significance and molecular basis. FASEB J. 9:1338-1343.

Hatziloukas, E. and N.J. Panopoulos. 1992. Origin, structure, and regulation of $\operatorname{argK}$, encoding the phaseolotoxin-resistant ornithine carbamoyltransferase in Pseudomonas-syringae pv phaseolicola, and functional expression of $\operatorname{argK}$ in transgenic plants. J. Bacteriol. 174:5895-5909.

Hayakawa, T., Y. Zhu, K. Itoh, Y. Kimura, T. Izawa, K. Shimamoto, and S. Toriyama. 1992. Genetically engineered rice resistant to rice stripe virus, an insect-transmitted virus. Proc. Natl. Acad. Sci. USA 89:9865-9869.

Hirano, S.S., L.S. Baker, and C.D. Upper. 1985. Ice nucleation temperature of individual leaves in relation to population sizes of ice nucleation active bacteria and frost injury. Plant Physiol. 77:259-265. 


\section{Colloquium}

Innes, R.W., S.R. Bisgrove, N.M. Smith, A.F. Bent, B.J. Staskawicz, and Y.C. Liu. 1993. Identification of a disease resistance locus in Arabidopsis that is functionally homologous to the RPG1 locus of soybean. Plant J. 4:813-820.

Johal, G.S. and S.P. Briggs. 1992. Reductase activity encoded by the HM1 disease resistance gene in maize. Science 258:985-987.

Jongedijk, E., M.J. Huisman, and J.C. Cornelissen. 1993. Agronomic performance and field resistance of genetically modified, virus-resistant potato plants. Seminars Virol. 4:407-416.

Kajava, A. and S.E. Lindow. 1993. A molecular model of the three-dimensional structure of bacterial ice nucleation proteins. J. Mol. Biol. 232:709-717.

Keen, N.T. 1992. The molecular biology of disease resistance. Plant Mol. Biol. 19:109-122.

Lamb, C.J. 1994. Plant disease resistance genes in signal perception and transduction. Cell 76:419-422.

Lindbo, J.A., L. Silva-Rosales, and W.G. Dougherty. 1993. Pathogen derived resistance to potyviruses: Working, but why? Seminars Virol. 4:369-379.

Lindemann, J. and T.V. Suslow. 1987. Competition between ice nucleation active wild-type and ice nucleation deficient deletion mutant strains of Pseudomonas syringae and $P$. fluorescens biovar I and biological control of frost injury on strawberry blossoms. Phytopathology 77:882-886.

Lindow, S.E. 1982. Population dynamics of epiphytic ice nucleation active bacteria on frost sensitive plants and frost control by means of antagonistic bacteria, p. 395-416. In: P.H. Li and A. Sakai (eds.). Plant cold hardiness. Academic, New York.

Lindow, S.E. 1983a. The role of bacterial ice nucleation in frost injury to plants. Annu. Rev. Phytopathol. 21:363-384.

Lindow, S.E. 1983b. Methods of preventing frost injury caused by epiphytic ice nucleation active bacteria. Plant Dis. 67:327-333.

Lindow, S.E. 1985a. Strategies and practice of biological control of ice nucleation active bacteria on plants, p. 293-311. In: N. Fokkema (ed.). Microbiology of the phyllosphere. Cambridge Univ. Press, London.

Lindow, S.E. 1985b. Ecology of Pseudomonas syringae relevant to the field use of Ice deletion mutants constructed in vitro for plant frost control, $\mathrm{p}$. 23-25. In: H.O. Halvorson, D. Pramer, and M. Rogul (eds.). Engineering organisms in the environment: Scientific issues. Amer. Soc. Microbiol., Washington, D.C.

Lindow, S.E. 1987. Competitive exclusion of epiphytic bacteria by Icemutants of Pseudomonas syringae. Appl. Environ. Microbiol. 53:25202527.

Lindow, S.E. 1990. Design and results of field trials of Ice ${ }^{-}$recombinant Pseudomonas syringae strains, p. 61-69. In: J. Marois and J. Bruhning (eds.). Risk assessment in agricultural biotechnology: Proceedings of the international conference. Univ. of California, Oakland.

Lindow, S.E., D.C. Arny, W.R. Barchet, and C.D. Upper. 1978a. The role of bacterial ice nuclei in frost injury to sensitive plants, p. 249-263. In: P. Li (ed.). Plant cold hardiness and freezing stress. Academic, New York.

Lindow, S.E., D.C. Arny, and C.D. Upper. 1978b. Distribution of ice nucleation active bacteria on plants in nature. Appl. Environ. Microbiol. 36:831-838.

Lindow, S.E., D.C. Arny, and C.D. Upper. 1982. Bacterial ice nucleation: A factor in frost injury to plants. Plant Physiol. 70:1084-1089.

Lindow, S.E., D.C. Arny, and C.D. Upper. 1983a. Biological control of frost injury. I: An isolate of Erwinia herbicola antagonistic to ice nucleationactive bacteria. Phytopathology 73:1097-1102.

Lindow, S.E., D.C. Arny, and C.D. Upper. 1983b. Biological control of frost injury. II: Establishment and effects of an antagonistic Erwinia herbicola isolate on corn in the field. Phytopathology 73:1102-1106.

Lindow, S.E. and J.H. Connell. 1984. Reduction of frost injury to almond by control of ice nucleation active bacteria. J. Amer. Soc. Hort. Sci. 109:4853.

Lindow, S.E. and N.J. Panopoulos. 1988. Field tests of recombinant Ice Pseudomonas syringae for biological frost control in potato, p. 121-138. In: M. Sussman, C.H. Collins, and F.A. Skinner (eds.). Proc. First Intl Conf. Release of Genetically Engineered Microorganisms. Academic, London.

Longstaff, M., G. Brigneti, F. Boccard, S. Chapman, and D. Baulcombe. 1993. Extreme resistance to potato virus $\mathrm{X}$ infection in plants expressing a modified component of the putative viral replicase. EMBO J. 12:379-386.

Maki, L.R., E.L. Galyon, M. Chang-Chien, and D.R. Caldwell. 1974. Ice nucleation induced by Pseudomonas syringae. Appl. Microbiol. 28:456460.

Mansky, L.M. and J.H. Hill. 1993. Molecular basis for virus disease resistance in plants. Arch. Virol. 131:1-16.
Martin, G.B., S.H. Brommonschenkel, J. Chunwongse, A. Frary, M.W. Ganal, R. Spivey, T. Wu, E.D. Earle, and S.D. Tanksley. 1993. Map-based cloning of a protein kinase gene conferring disease resistance in tomato. Science 262:1432-1436.

Mindrinos, M., F. Katagiri, G.L. Yu, and F.M. Ausubel. 1994. The A. thaliana disease resistance gene rps 2 encodes a protein containing a nucleotidebinding site and leucine-rich repeats. Cell 78:1089-1099.

Mitchell, R.E. 1976. Isolation and structure of a chlorosis-inducing toxin of Pseudomonas phaseolicola. Phytochemistry 15:1941-1947.

Modlibowska, I. 1962. Some factors affecting supercooling of fruit blossoms. J. Hort. Sci. 37:249-261.

Moffat, A.S. 1994. Plant genetics. Mapping the sequence of disease resistance. Science 265:1804-1805.

Mosqueda, G., G. Van Den Broeck, O. Saucedo, A.M. Bailey, A. AlvarezMorales, and L. Herrera-Estrella. 1990. Isolation and characterization of the gene from Pseudomonas syringae pv. phaseolicola encoding the phaseolotoxin-insensitive ornithine carbamoyltransferase. Mol. Gen. Genet. 222:461-466.

Nejidat, A. and R.N. Beachy. 1990. Transgenic tobacco plants expressing a coat protein gene of tobacco mosaic virus are resistant to some other tobamoviruses. Mol. Plant-Microbe Interactions 3:247-251.

Orser, C.S., B.J. Staskawicz, N.J. Panopoulos, D. Dahlbeck, and S.E. Lindow. 1985. Cloning and expression of bacterial ice nucleation genes in Escherichia coli. J. Bacteriol. 164:359-366.

Powell-Abel, P., R.S. Nelson, B. De, N. Hoffmann, S.G. Rogers, R.T. Fraley, and R.N. Beachy. 1986. Delay of disease development in transgenic plants that express the tobacco mosaic virus coat protein gene. Science 232:738-743.

Rajashekar, C., P.H. Li, and J.V. Carter. 1983. Frost injury and heterogeneous ice nucleation in leaves of tuber-bearing Solanum species. Plant Physiol. 71:749-755.

Reimann-Philipp, U. and R.N. Beachy. 1993. The mechanism(s) of coat protein-mediated resistance against tobacco mosaic virus. Seminars Virol. 4:349-356.

Ruvkun, G.B. and F.M. Ausubel. 1981. A general method for site-directed mutagenesis in prokaryotes. Nature (London) 289:85-88.

Sanford, J.C. and S.A. Johnston. 1985. The concept of parasite-derived resistance-Deriving resistance genes from the parasite's own genome. J. Theor. Biol. 113:395-405.

Schoelz, J. and W.M. Wintermantel. 1993. Expansion of viral host range through complementation and recombination in transgenic plants. Plant Cell 5:1669-1679.

Scholthof, K-B.G., H.B. Scholthof, and A.O. Jackson. 1993. Control of plant virus diseases by pathogen-derived resistance in transgenic plants. Plant Physiol. 102:7-12.

Staskawicz, B.J., N.J. Panopoulos, and N.J. Hoogenraad. 1980. Phytotoxininsensitive ornithine carbamoyltransferase of Pseudomonas syringae pv. phaseolicola. Basis for immunity to phaseolotoxin. J. Bacteriol. 142:720723.

Tepfer, M. 1993. Viral genes and transgenic plants. Bio/Technology 11:11251131.

Warren, G.J. 1987. Bacterial ice nucleation: Molecular biology and applications. Biotechnol. Gen. Eng. Rev. 5:107-135.

Warren, G. and L. Corotto. 1989. The consensus sequence of ice nucleation proteins from Erwinia herbicola, Pseudomonas fluorescens and Pseudomonas syringae. Gene 85:239-242.

Warren, G. and P. Wolber. 1991. Molecular aspects of microbial ice nucleation. Mol. Microbiol. 5:239-243.

Whitham, S., S.P. Dinesh-kumar, D. Choi, R. Hehl, C. Corr, and B. Baker. 1994. The product of the tobacco mosaic virus resistance gene N. Similarity to toll and the interleukin-1 receptor. Cell 78:1101-1115.

Wilson, M. and S.E. Lindow. 1993. Release of recombinant microorganisms. Annu. Rev. Microbiol. 47:913-944.

Wisniewski, L.A., P.A. Powell, R.S. Nelson, and R.N. Beachy. 1990. Local and systemic spread of tobacco mosaic virus in transgenic tobacco. Plant Cell 2:559-567.

Wolber, P.K. 1992. Bacterial ice nucleation. Advances Microbiol. Physiol. 34:205-237.

Wolber, P. and G. Warren. 1989. Bacterial ice-nucleation proteins. Trends Biochem. Sci. 14:179-182.

Zaitlin, M., J.M. Anderson, K.L. Perry, L. Zhang, and P. Palukaitis. 1994. Specificity of replicase-mediated resistance to cucumber mosaic virus. Virology 201:200-205. 


\title{
Role of Calcium in Plant Responses to Stresses: Linking Basic Research to the Solution of Practical Problems
}

\author{
Jiwan P. Palta \\ Department of Horticulture, University of Wisconsin, Madison, WI 53706
}

\begin{abstract}
There is ample evidence for the role of $\mathrm{Ca}$ in plant growth and development and in maintenance and modulation of various cell functions (Hanson, 1984; Kirby and Pilbeam, 1984; Leonard and Hepler, 1990; Poovaiah and Reddy, 1993). This evidence is based on the well-recognized importance of $\mathrm{Ca}^{2+}$ in membrane structure and function as well as in cell wall structure. For example, it is essential to have $\mathrm{Ca}^{2+}$ in the extracellular solution to ensure the maintenance of selective permeability, i.e., membrane integrity. It is also well known that $\mathrm{Ca}^{2+}$ is an integral part of the cell wall where it provides stable, but reversible, intramolecular linkages between pectic molecules, resulting in cell wall rigidity. In addition, $\mathrm{Ca}^{2+}$ stabilizes cell membranes by bridging phosphate and carboxylate groups of phospholipids at the membrane surface (Legge et al., 1982). Presence of extracellular $\mathrm{Ca}^{2+}$ increases bonds between the cell wall and plasma membrane (see Gomez-Lepe et al., 1979). Interestingly, $\mathrm{Ca}^{2+}$ is a nontoxic mineral nutrient and plant cells can tolerate high concentrations of extracellular $\mathrm{Ca}^{2+}$ (Palta and Lee-Stadelmann, 1983).
\end{abstract}

In addition to its role in the cell wall and membrane, $\mathrm{Ca}^{2+}$ is now regarded as an important intracellular secondary messenger (for details, see Poovaiah and Reddy, 1993). Various studies have provided strong evidence implicating the regulation of various cell functions by cytosolic (free) $\mathrm{Ca}^{2+}$ concentration. These studies suggest that $\mathrm{Ca}^{2+}$ is a messenger in transducing external stimuli in plants. These signals often use plasma membrane-associated protein kinases, phosphatidylinositol pathways, or both (Poovaiah and Reddy, 1987).

Many environmental and hormonal signals [touch, wind, gravity, light, cold, auxin, gibberellic acid (GA), abscisic acid (ABA), salt, fungal elicitors] induce changes in cytosolic $\mathrm{Ca}^{2+}$ levels that precede the physiological responses (for details, see Poovaiah and Reddy, 1993). Thus, the impact of environmental and biotic stresses on plants can be mediated by cytosolic $\mathrm{Ca}^{2+}$. For example, recent evidence suggests such a role of $\mathrm{Ca}$ in cold acclimation (Dhindsa and Monroy, 1994; Monroy et al., 1993). In addition, environmental stresses, such as heat, freezing temperatures, and salinity, and biotic stresses are known to cause perturbation in cell membranes, cell walls, or both. Therefore, Ca could be expected to play an important role in plant responses to environmental and biotic stresses. In this article, I illustrate this role of $\mathrm{Ca}$ in three stresses: freezing, biotic, and heat. Examples from our own studies show that, in addition to providing insight into mechanisms of plant responses to stresses, we were able to develop practical solutions to stress-related problems. Our results suggest that manipulation of membrane, cellular, and tissue Ca may be an approach to bridging the gap between science and technology.

\section{ROLE OF CALCIUM IN FREEZING STRESS}

\section{Enhanced ion efflux following freeze-thaw stress is mitigated} by extracellular $\mathrm{Ca}^{2+}$

Freezing injury results in increased efflux of ions from plant tissues (Palta et al., 1977a, 1977b). Potassium is the major cation that leaks out of cells (Palta et al., 1977a). From these results, it was suggested that alteration in the $\mathrm{K}^{+}$permeability of the cell membranes was an early

Received for publication 25 May 1995. Accepted for publication 24 July 1995. Some of the research summarized here was funded by the College of Agriculture and Life Sciences, Univ. of Wisconsin, Madison, and by the Wisconsin State Potato Board. I thank Navjot Kaur for typing this manuscript and Bjorn Karlsson for helping in preparing figures. The cost of publishing this paper was defrayed in part by the payment of page charges. Under postal regulations, this paper therefore must be hereby marked advertisement solely to indicate this fact. symptom of freeze-thaw injury (Palta and Li, 1978, 1980). In a followup study, Arora and Palta (1989) demonstrated that $\mathrm{K}^{+}$efflux rate following freeze-thaw injury is markedly reduced in the presence of extracellular $\mathrm{Ca}^{2+}$. For example, in freeze-thaw-injured onion (Allium cepa $\mathrm{L}$.) bulb cells, $\mathrm{K}^{+}$efflux rate was reduced by half in the presence of $20 \mathrm{~mm} \mathrm{CaCl}_{2}$ in the bathing medium as compared to distilleddeionized water (Table 1 ). In a related study, $\mathrm{K}^{+}$efflux from onion bulb tissue was reduced by half with $25 \mathrm{~mm}$ extracellular $\mathrm{CaCl}_{2}$, whereas equivalent concentrations of $\mathrm{NaCl}$ had no effect on $\mathrm{K}^{+}$efflux (Arora and Palta, 1986). These results suggest that $\mathrm{Ca}^{2+}$ is able to mitigate freeze-induced injury to the membranes that is responsible for leakage of $\mathrm{K}^{+}$.

Protoplasmic swelling as a microscopic symptom of freezing injury: It can be simulated by bathing tissue in $\mathrm{K}^{+}$and prevented by $\mathrm{Ca}^{2+}$

As discussed above, freeze-thaw stress results in enhanced ion $\left(\mathrm{K}^{+}\right)$efflux from the cells. In spite of this dramatic change in cell membrane permeability, the cells remain viable, i.e., they can be plasmolyzed, they exhibit protoplasmic streaming, and they can be stained with fluorescent diacetate (Arora and Palta, 1988; Palta et al., 1977a). Depending on the extent of freeze-thaw stress, these cells either recovered or injury progressed with time during the post-thaw period (Arora and Palta, 1991; Palta et al., 1977b). During the progress of injury, the first visual microscopic system detected was protoplasmic swelling (Palta and Li, 1980).

To examine this symptom further, Arora and Palta (1988) used red onions in which the vacuole and cytoplasm are easily visualized because the vacuole is red and the cytoplasm colorless (Fig. 1). Since cytoplasm occupies $<10 \%$ of the total cell volume, it can only be recognized as a thin coating over the red vacuole in nonfrozen control cells. This was true in the normal (Fig. 1a) and plasmolyzed conditions (Fig. 1b). However, in freeze-thaw-injured cells, the vacuole retracted as a result of protoplasmic swelling (Fig. 1c). Protoplasmic swelling was seen easily when these cells were plasmolyzed (Fig. 1d).

Palta and Li (1980) proposed that this cellular symptom results from the secondary injury caused by a high concentration of extracellular $\mathrm{K}^{+}$, which is present in freeze-thaw-injured cells. We also proposed that injury results when extracellular $\mathrm{K}^{+}$removes $\mathrm{Ca}^{2+}$ from the outer face of the plasma membrane. This removal causes "weakness" in the structure of the plasma membrane. Support for this notion also comes through displacement of membrane $\mathrm{Ca}^{2+}$ by extracellular $\mathrm{Na}^{+}$(Cramer et al., 1985). Later, Arora and Palta (1986) demonstrated that protoplasmic swelling can be produced within 30 min by bathing normal cells in $50 \mathrm{~mm} \mathrm{KCl}$. Furthermore, they showed that the development of these symptoms by $\mathrm{KCl}$ could be prevented by adding 10 to $20 \mathrm{mM} \mathrm{CaCl}_{2}$ to the bathing medium. These results further support the idea that by maintaining a certain level of $\mathrm{Ca}^{2+}$ in the membrane, one can mitigate the injury due to freeze-thaw and alkalinity $\left(\mathrm{Na}^{+}\right)$ stresses.

Table 1. Effect of extracellular $\mathrm{CaCl}_{2}$ on $\mathrm{K}^{+}$efflux rate in control and freezeinjured onion scale tissue (source: Arora and Palta, 1989).

\begin{tabular}{lcc}
\hline & \multicolumn{2}{c}{$\mathrm{K}^{+}$efflux/ $/ \mathrm{h}^{\mathrm{z}}$ in the presence of } \\
\cline { 2 - 3 } Frozen & $\mathrm{H}_{2} \mathrm{O}$ & $20 \mathrm{mM} \mathrm{CaCl}_{2}$ \\
\hline No (control) & $14.8 \pm 1.6^{\mathrm{y}}$ & $8.1 \pm 0.3$ \\
Yes (-11.0C) & $47.1 \pm 5.0$ & $24.6 \pm 2.3$ \\
\hline
\end{tabular}

${ }^{2}$ Calculated as percent total cellular $\mathrm{K}^{+}$.

${ }^{\mathrm{y}}$ Mean of three replications $\pm \mathrm{SE}$. 

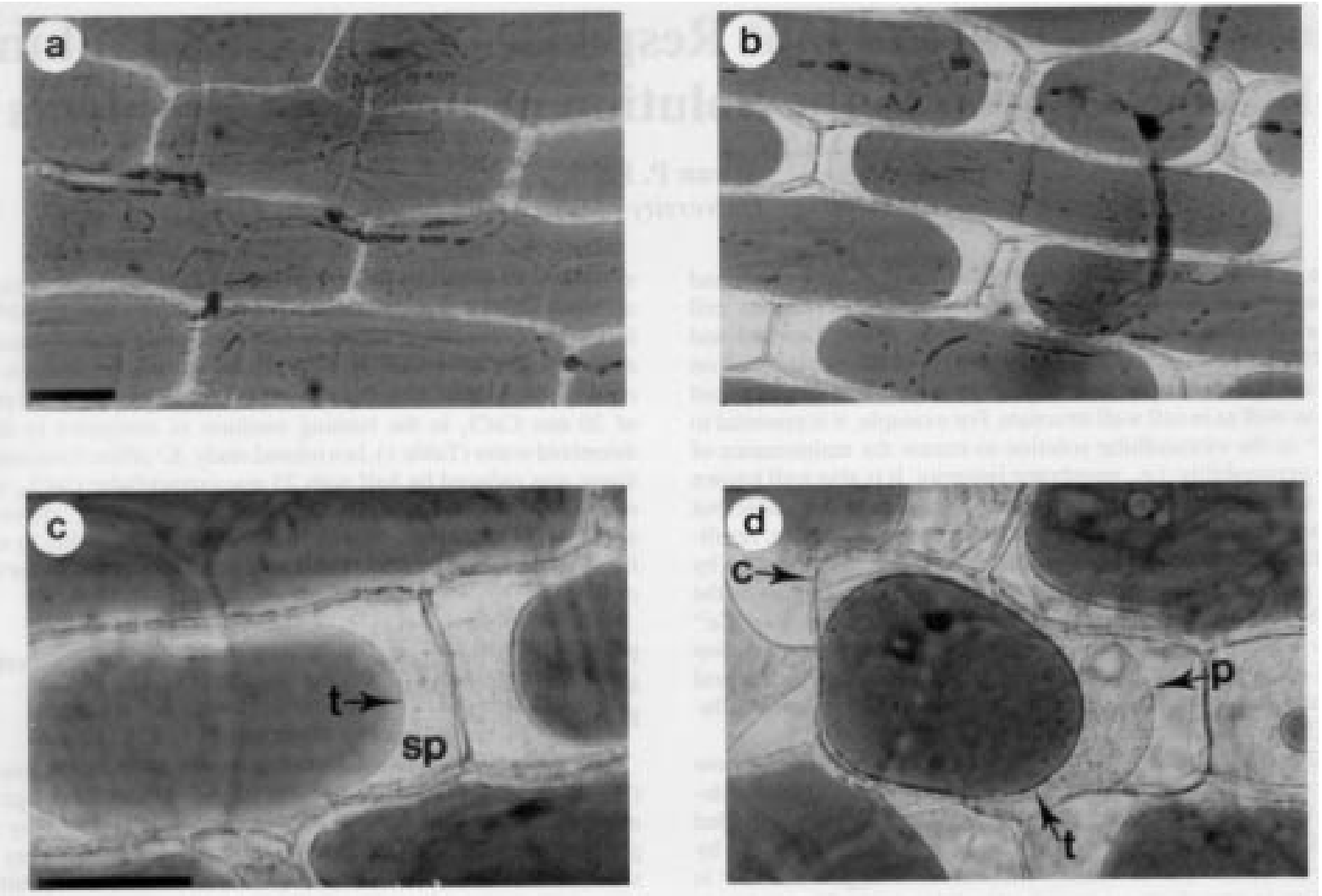

Fig. 1. Photomicrographs of abaxial onion epidermal cells showing the protoplasmic swelling that is symptomatic of freezing injury. (a) Control cells in tap water; (b) plasmolysis of (a) in $0.8 \mathrm{~m}$ mannitol solution; (c) freeze-injured cells just after thawing showing retracted vacuole and swollen protoplasm; (d) plasmolysis of (c) in $0.8 \mathrm{~m}$ mannitol solution to separate swollen protoplasm from the cell wall and visualize plasma membrane. $\mathrm{c}=$ Cell wall; $\mathrm{t}=\mathrm{tonoplast;} \mathrm{p}=\mathrm{plasma}$ membrane; $\mathrm{sp}=$ swollen protoplasm. Bars in (a) and (c) equal $50 \mu \mathrm{m}$ (source: Arora and Palta, 1986).

\section{Loss of membrane-associated $\mathrm{Ca}^{2+}$ : A key process in the initiation and progression of freezing injury}

Using chlorotetracycline (CTC) as a fluorescent probe for membrane-associated $\mathrm{Ca}^{2+}$, Arora and Palta (1991) demonstrated that a specific loss of membrane $\mathrm{Ca}^{2+}$ occurred following reversible (recoverable) and irreversible freezing injury (Fig. 2). There was a direct relationship between ion leakage and membrane-associated $\mathrm{Ca}^{2+}$ (Fig. 3 ). Injured cells with a possibility of recovery showed significant loss of membrane $\mathrm{Ca}^{2+}$ (Fig. 2). These results suggest that loss of membrane $\mathrm{Ca}^{2+}$ is associated with early events of freezing injury. Further, these results lend support to the notion that one way to mitigate the injurious impact of freeze-thaw stress is to enhance the ability of the cell to maintain a certain level of membrane $\mathrm{Ca}^{2+}$.

\section{Practical applications}

Pretreatment with extracellular $\mathrm{Ca}^{2+}$ enhances tolerance to freezethaw stress. In support of the above discussion, we have found that pretreatment of onion bulb scale tissue with $20 \mathrm{mM} \mathrm{CaCl}_{2}$ before freezing enhanced its tolerance to freeze-thaw stress as measured by the tetrazolium chloride (TTC) reduction assay (Table 2), whereas pretreatment of this tissue with $1 \mathrm{~mm}$ ethylene glycol tetraacetic acid (EGTA) reduced its tolerance. Since EGTA is known to remove (chelate) $\mathrm{Ca}^{2+}$, these results support the view that by maintaining certain levels of $\mathrm{Ca}^{2+}$ in the tissue, one may be able to enhance its tolerance to freeze-thaw stress. The protective effect of $\mathrm{Ca}^{2+}$ in freezing stress also was demonstrated by Pomeroy and Andrews (1985), who found that wheat (Triticum aestivum L.) cell cultures treated with $\mathrm{Ca}^{2+}$ survived much better following ice encasement than the nontreated cultures. Thus, it would appear that, on a practical level, one should be able to improve freezing tolerance by increasing $\mathrm{Ca}$ concentration of the tissue. In other words, in a field situation, we can expect to improve freezing tolerance with $\mathrm{Ca}^{2+}$ fertilization. We have to be careful, however, in making such a recommendation-the response from supplemental $\mathrm{Ca}^{2+}$ application will vary with soil type, available soil $\mathrm{Ca}^{2+}$, and type of crop. Obviously, we can expect better response by $\mathrm{Ca}^{2+}$ fertilization in tissues and plants that are otherwise deficient in $\mathrm{Ca}^{2+}$.

\section{ROLE OF CALCIUM IN BIOTIC STRESSES}

\section{Potato tuber quality and $\mathrm{Ca}^{2+}$}

Bacterial soft rot of potatoes (Solanum tuberosum L.) during storage, caused by Erwinia carotovora pv. atroseptica, decreases as tissue Ca concentration increases (McGuire and Kelman, 1984, 1986). Depending on the cultivar and storage condition, $4 \%$ to $38 \%$ of stored potatoes can be infected (Varns et al., 1985). In addition, the incidence of several disorders of tubers, such as internal brown spots, hollow heart, and brown center, also decreases as tissue Ca concentration increases (Collier et al., 1978; Tzeng et al., 1986). Our recent studies have confirmed the beneficial effect of supplemental $\mathrm{Ca}$ fertilization on tuber quality (Tawfik and Palta, 1992a, 1992b). Thus, significant improvement in tuber quality and storability can be made by increasing the $\mathrm{Ca}$ content of tubers.

\section{Tubers, low-transpiring organs, are naturally deficient in Ca}

Since Ca moves along with water in the xylem, transpiration is the main driving force for Ca transport in plants (Clarkson, 1984). Potato tubers, being surrounded by moist soil, will have much less transpiration as compared to the above-ground part of the plant. Consequently, low-transpiring organs, such as fruits and tubers, will accumulate much less Ca per unit fresh weight than leaves. Calcium deficiency in tuber tissue is even greater for potatoes grown in sandy soil, such as in central Wisconsin, the major potato-growing area of the state, because of the low level of exchangeable $\mathrm{Ca}^{2+}$ in these soils. Moreover, with constant irrigation, water-soluble $\mathrm{Ca}^{2+}$ will be depleted from the top of the hill where most of the tubers form. 

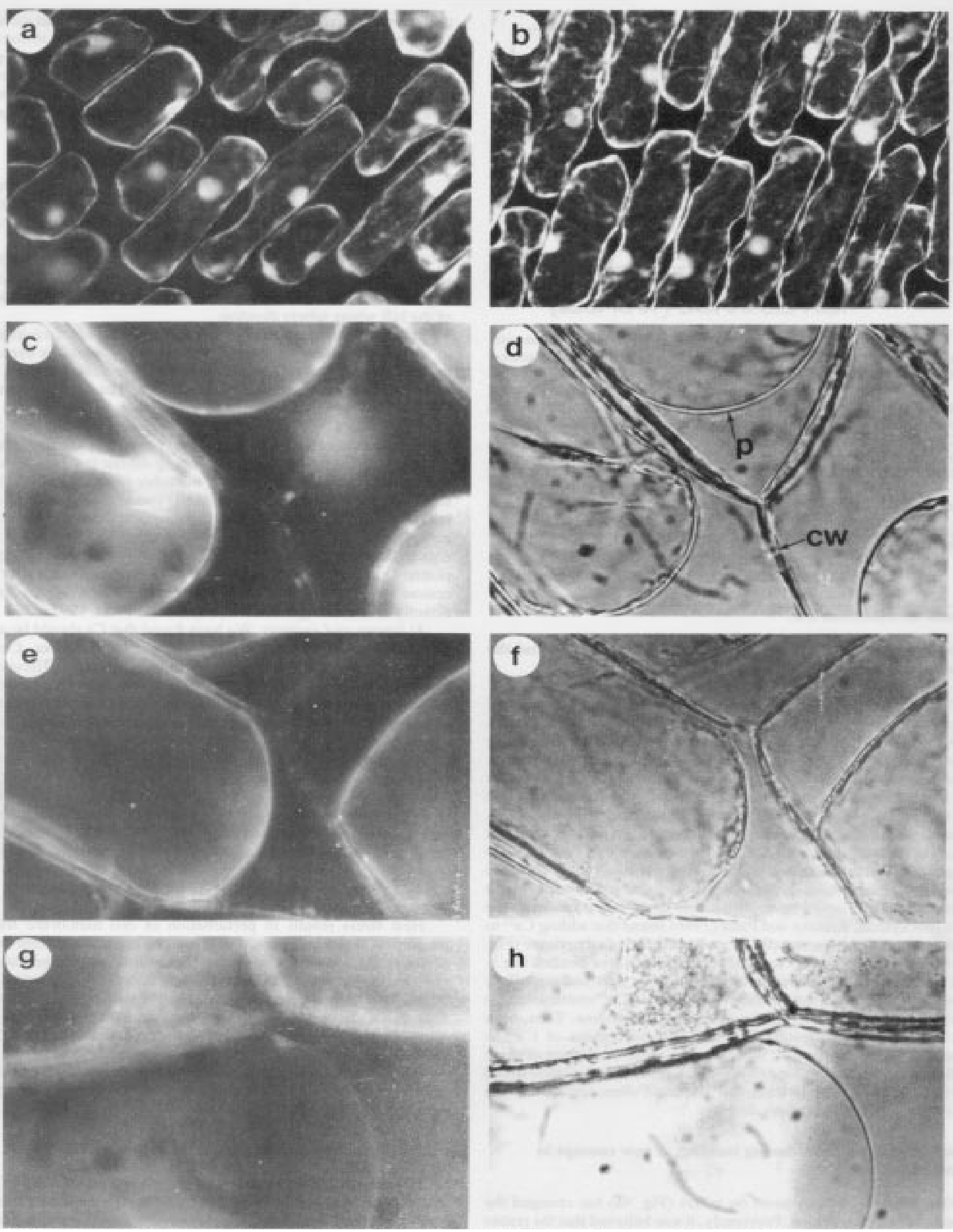

Fig. 2. Photomicrographs of adaxial epidermal cells of onion bulb (nonfrozen control and freeze-thaw-stressed) treated with fluorescein diacetate (FDA) and chlorotetracycline (CTC) staining solutions. (a) Control cells showing fluorescence from FDA staining; (b) freeze-thaw-stressed (-11.5C) cells showing fluorescence from FDA staining; (c) control cells exhibiting $\mathrm{Ca}^{2+}$ CTC fluorescence; (d) bright field picture of (c); (e) freeze-thaw-stressed (-8.5C) cells showing $\mathrm{Ca}^{2+}-\mathrm{CTC}$ fluorescence; (f) bright field picture of (e); (g) freeze-thaw-stressed $(-11.5 \mathrm{C})$ cells showing $\mathrm{Ca}^{2+}-\mathrm{CTC}$ fluorescence; (h) bright field picture of $(\mathrm{g}) . \mathrm{cw}=$ Cell wall; $\mathrm{p}=$ protoplasmic surface (plasma membrane). Magnification in (a) and (b) was $\times 180$ and in (c) to (h) $\times 500$ (source: Arora and Palta, 1988). 


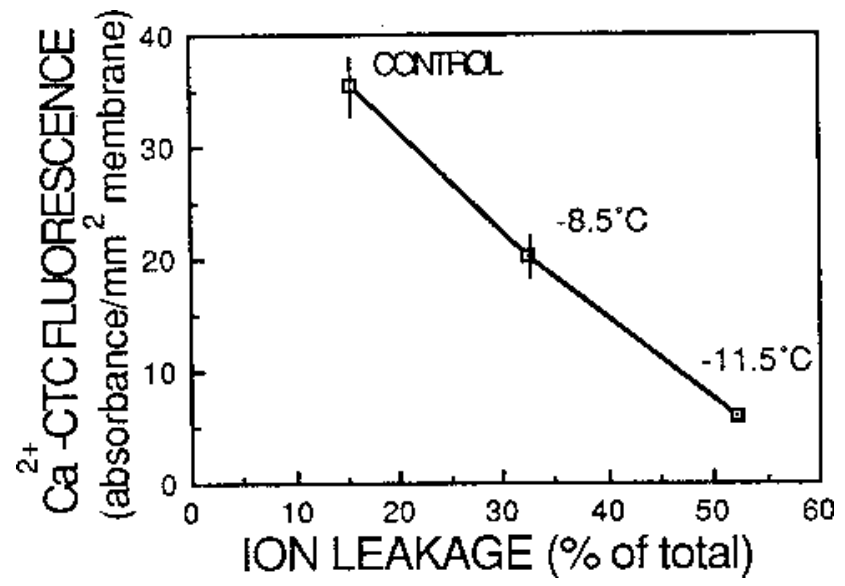

Fig. 3. Relationship between freezing injury (ion leakage) and membraneassociated $\mathrm{Ca}^{2+}-$ chlorotetracycline (CTC) fluorescence (means $\pm \mathrm{SE}$ ) (source: Arora and Palta, 1988).

Table 2. Effect of $\mathrm{CaCl}_{2}$ and a 2-h ethylene glycol tetraacetic acid (EGTA) pretreatment on cell viability of onion scale tissue after freeze-thaw stress. Cell viability was assessed by the tetrazolium chloride (TTC) reduction method (Palta et al., 1981) (source: Arora and Palta, 1989).

\begin{tabular}{lccc}
\hline \hline \multirow{2}{*}{ Freezing temp } & \multicolumn{3}{c}{ TTC reduction (\%) when treated with } \\
\cline { 2 - 3 }$\left({ }^{\circ} \mathrm{C}\right)$ & \multicolumn{2}{c}{$\mathrm{CaCl}_{2}(\mathrm{~mm})$} & $\frac{\text { EGTA }(\mathrm{mM})}{1}$ \\
\cline { 2 - 4 } None (control) & 100 & 100 & 100 \\
-3 & $37.6 \pm 4.2^{\mathrm{z}}$ & $79.5 \pm 8.3$ & $28.6 \pm 2.7$ \\
-5 & $11.6 \pm 1.3$ & $24.2 \pm 3.1$ & $13.5 \pm 1.6$ \\
-7 & $8.0 \pm 0.9$ & $6.3 \pm 0.5$ & $10.0 \pm 0.8$ \\
\hline
\end{tabular}

${ }^{\mathrm{z}}$ Mean of six replications $\pm \mathrm{sE}$.

Discovery of tuber roots: Application of soluble $\mathrm{Ca}^{2+}$ around the tuber area can enhance tuber $\mathrm{Ca}^{2+}$ uptake

Over 10 years ago, we provided evidence for the existence of functional roots on the tuber (Fig. 4a) and at the tuber-stolon junction (Kratzke and Palta, 1985). In a follow-up study, we showed that these tuber roots displayed normal root anatomy; also, they appear to derive from parenchyma cells adjacent to the vascular tissue (Struckmeyer and Palta, 1986). By feeding a water-soluble dye, we demonstrated that these roots were able to supply water to the tuber (Fig. $4 \mathrm{c}$ and d), whereas the main root system supplied water to the top part of the plant (Fig. 4b). Since water and $\mathrm{Ca}$ are known to move together, we suggested that these tuber and stolon roots are able to supply Ca to the tuber (Kratze and Palta, 1985). Using a divided-pot system, where supplemental $\mathrm{Ca}^{2+}$ could be applied either in the tuber area or to the main root system, Kratzke and Palta (1986) found that adding $\mathrm{Ca}^{2+}$ to the main root system increased $\mathrm{Ca}^{2+}$ concentration of tuber tissue (Fig. 5). However, applying $\mathrm{Ca}^{2+}$ to the tuber and stolon area resulted in a 3 fold increase in $\mathrm{Ca}^{2+}$ concentration in the tuber peel and medullary tissue (Fig. 5). These results showed that tuber $\mathrm{Ca}^{2+}$ content can be increased by placing $\mathrm{Ca}^{2+}$ in the tuber and stolon area. Thus, on a practical level, these results indicated that placement of $\mathrm{Ca}^{2+}$ is important for enhancing $\mathrm{Ca}^{2+}$ uptake by the tuber. In support of these studies, Simmons and Kelling (1987) and Simmons et al. (1988) found that maximum increase in tuber $\mathrm{Ca}^{2+}$ occurred when applied $\mathrm{Ca}$ was mixed in the hill where tubers develop.

\section{Spoon feeding potatoes during bulking: A new concept in potato nutrition}

Our discovery of tiny roots on tubers (Fig. 4a) has changed the concept of potato nutrition. Previously, it was believed that the potato plant's main roots supplied all the water and nutrients to the leaves, and the leaves in turn feed the tubers. In contrast, our results clearly show that potato tubers are like "underground plants" that draw their water and nutrients, such as $\mathrm{Ca}$, directly from the soil. Since tubers are surrounded by moist soil, they cannot compete with leaves for transpi- rational water uptake. Tubers thus have to rely on roots that are in their close proximity (tuber roots, tuber-stolon junction roots, stolon roots) to extract water from the soil. Since Ca moves in xylem along with water, it follows that potato tubers must extract $\mathrm{Ca}$ from the soil in their close proximity. These results have lead to the development of a concept of "spoon feeding" Ca to the tubers during the bulking period.

\section{Practical applications}

Three practical questions, for enhancing tuber quality through tuber Ca nutrition, have been addressed by our research: 1) where to apply $\mathrm{Ca}$ (i.e., placement); 2) when to apply $\mathrm{Ca}$ (i.e., timing); 3) what source of $\mathrm{Ca}$ is most effective.

1) Placement. Our results show that tubers take up Ca from the soil surrounding the tuber and stolon area. Thus, to enhance Ca concentration in the tubers, it is important that $\mathrm{Ca}$ be added in the upper portion of the hill where tubers develop.

2) Timing. Because tubers develop late in the season, it is important to add supplemental $\mathrm{Ca}$ during tuber bulking, which is even more critical in sandy soils. Due to low moisture-holding capacity, sandy soils are irrigated two to three times a week. Thus, the top portion of the hill is continuously washed by irrigation and rain, with water moving soluble nutrients to the lower portion of the hill. These nutrients remain accessible to vegetative growth via the main root system. However, the tubers developing during late season will not have access to these nutrients via the tuber or stolon roots. Thus, to enhance tuber Ca uptake, we need to "spoon feed" potatoes during bulking with Ca fertilizer. Before our research, potato growers used to complete fertilization at hilling. This was a necessity, because nutrients could not be applied by tractor after hilling without damaging the plants. Our results show that $\mathrm{Ca}$ needs to be made much later in the season and that this can be easily achieved by injecting Ca fertilizer directly into the irrigation line (Tawfik and Palta, 1992a).

3) Source and quantity. We have found that Ca should be applied in water-soluble form to facilitate uptake by the tuber. Common sources of $\mathrm{Ca}$ used in agriculture are lime and gypsum. These chemicals have low water solubility. Because we are injecting the fertilizer into the irrigation line, we have used two water-soluble sources of $\mathrm{Ca}$ available in the market - calcium nitrate (Hydro Agri of North America) and NHIB (Stoller Chemical Co.). We have injected these two products separately and found them to be effective in increasing tuber $\mathrm{Ca}$ (Tawfik and Palta, 1992a). Applications were made during tuber bulking in three split doses (hilling and 3 and 6 weeks after hilling). Our results demonstrate that it is possible to improve tuber Ca content and, thereby, tuber quality by applying 113 to $226 \mathrm{~kg} \mathrm{Ca} / \mathrm{ha}$ during bulking, even in soil that contained sufficient $\mathrm{Ca}$ for potato plant growth.

\section{ROLE OF CALCIUM IN HEAT STRESS}

Heat stress results in perturbation of cell membrane transport properties. It can be detected as enhanced ion leakage from the cells (Palta et al., 1981). Extracellular Ca reduces membrane leakage at elevated temperatures (Cooke et al., 1986; Toprover and Glinka, 1976). These results suggest that Ca may be able to protect plants from heat stress. Recently, we have found evidence in support of this suggestion (Tawfik and Palta, 1992b). We studied the impact of Ca on potato plant growth and tuber production during heat stress. These results not only provide some insight into the physiological role of $\mathrm{Ca}$ in heat stress, but also provide an avenue for mitigating heat stress on plants in the field.

\section{Potato: A cool-season crop sensitive to heat stress}

Heat stress reduces potato plant growth and partitioning of photosynthate to the tubers (Ewing, 1981). Although there are differences among cultivars in their response to heat stress, in general, day maxima more than 25 to $30 \mathrm{C}$ tend to increase stem length and branches while reducing leaf size and total leaf area (Benoit et al., 1983; Khedher and Ewing, 1985; Manrique, 1990). These morphological changes dramatically reduce the leaf : stem ratio under heat stress (Bodlaender, 1963; Burton, 1989; Khedher and Ewing, 1985; Steward et al., 1981). 

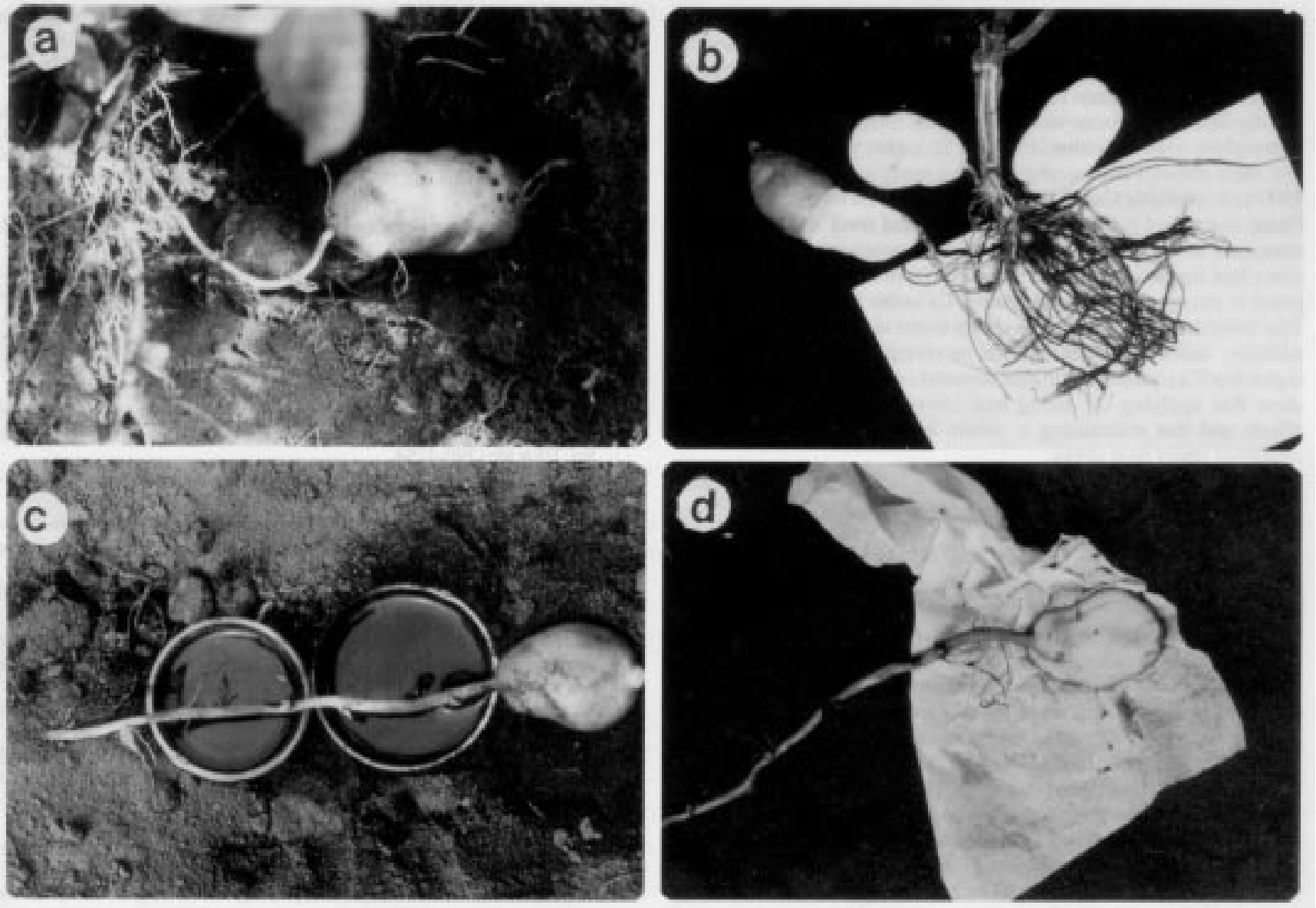

Fig. 4. Evidence for the existence of functional roots on 'Russett Burbank' potato tubers and stolons and study of the transport of water-soluble dye from various roots to the tuber. (a) Growing tubers with tuber roots; (b) dye given to main roots is transported to the leaves and not to the tubers; (c) feeding the dye to stolon roots; (d) movement of dye from stolon roots to the tuber (source: Kratzke and Palta, 1985).

In addition, high temperatures also reduce the net assimilation rate (Midmore and Prange, 1992; Steffen et al., 1995). Overall, the result of all these effects of heat stress on potato plants is a decrease in plant growth and tuber yield.

\section{Heat stress effects on potatoes can be mitigated by Ca}

Summer 1988 was unusually warm and dry in Wisconsin. The daily air maxima temperature between 1 June and 18 Aug. at the

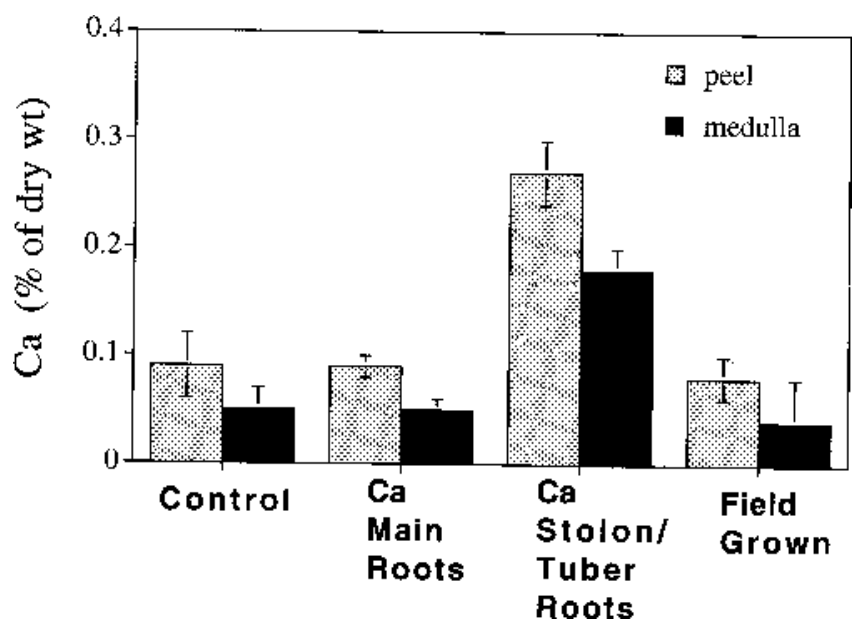

Fig. 5. Tuber Ca concentration as influenced by placement of water-soluble Ca. Fertilizer $\left(\mathrm{CaCl}_{2}\right)$ was selectively given to the main roots or to the tuber and stolon in divided pot system (source: Kratzke and Palta, 1986).
Hancock Experimental Station was at or above 32C for 46 days. The rainfall during June, July, and August was 47, 140, and $100 \mathrm{~mm}$, respectively, at this location. On average, there was a $25 \%$ decrease in tuber yield in the central sands (where Hancock Experimental Station is located) of Wisconsin. In our field trails at Hancock, we found a $20 \%$ to $30 \%$ increase in tuber yields when soluble Ca (calcium nitrate or NHIB) was applied during the tuber bulking period (Fig. 6). There was no significant difference in tuber yield among the two sources of $\mathrm{Ca}$. These results suggest that $\mathrm{Ca}$ fertilization during

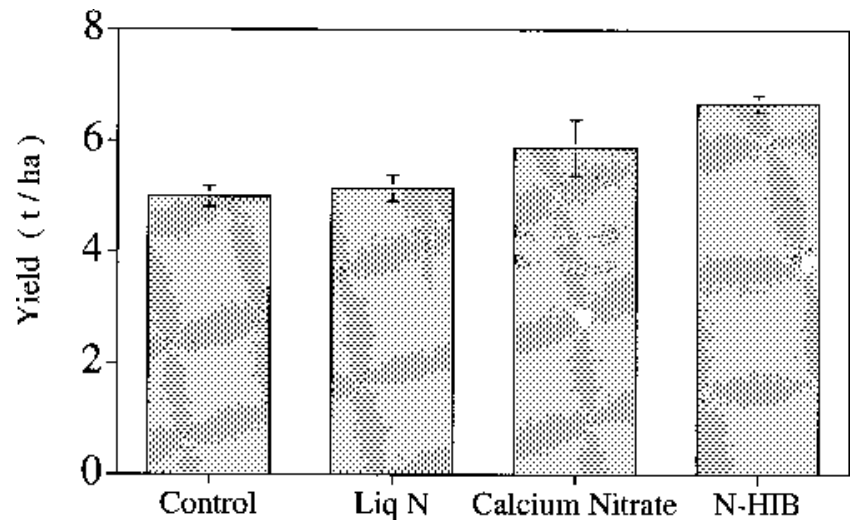

Fig. 6. Impact of $\mathrm{Ca}$ and $\mathrm{N}$ application, during tuber bulking period, on potato tuber yield under heat stress conditions. Field plots were established in 1988 at the Univ. of Wisconsin Hancock Experimental Station. All plots were irrigated with a central pivot system and were grown under standard fertility and cultural practices. Calcium application was made by injecting watersoluble forms of fertilizers (calcium nitrate or NHIB) into the irrigation line. Values are means of five separate locations for yield measurement. 
bulking could mitigate the adverse impact of heat stress on tuber yield.

Following these observations in 1988, we have conducted several studies on the impact of heat stress on potato plants under controlled environmental conditions (Tawfik and Palta, 1992b). In these studies, side-by-side comparisons were made on the impact of Ca nutrition on potato plants grown at either 20C day/15C night cycles (normal) or 30/ $15 \mathrm{C}$ (heat stress). Plants were grown in a sandy loam soil that tested at $1500 \mathrm{~kg} / \mathrm{h}$ available $\mathrm{Ca} / \mathrm{h}$ (adequate amount of $\mathrm{Ca}$ for potato growth). Plants under heat stress had reduced total leaf fresh and dry weights compared to the control. However, plants receiving $\mathrm{Ca}$ under heat stress had significantly higher total leaf fresh and dry weights compared to plants with no supplemental $\mathrm{Ca}$ under identical conditions. This beneficial effect of $\mathrm{Ca}$ was absent under nonstress conditions. In addition, under heat stress, plants receiving supplemental $\mathrm{Ca}$ had higher leaf Ca contents and higher stomatal conductance. These results show that applying $\mathrm{Ca}$ during heat stress can mitigate heat stress effects and that maintaining a certain level of $\mathrm{Ca}$ in leaf tissue is important under heat stress.

\section{Physiological basis for mitigation of heat stress effects on potatoes}

Although we do not know the mechanism by which $\mathrm{Ca}$ is able to mitigate heat stress effects on potatoes, our results provide some insight. For example, we found that stomatal conductance was higher in Ca-treated than control plants under heat stress (Tawfik and Palta, 1992b). This result would be relevant in avoiding heat stress effects via enhanced transpirational water loss. There is some evidence for the regulation of stomatal function by cytosolic calcium $\mathrm{Ca}^{2+}$ (Irving et al., 1992; Schwartz et al., 1988), although the exact mechanism remains to be elucidated (Kearns and Assmann, 1993). We found a decrease in the $\mathrm{Ca}$ concentration in leaves of potato plants exposed to heat stress, but the $\mathrm{Ca}^{2+}$ concentration was maintained at the same level as before heat stress in the leaves of plants given $\mathrm{Ca}$ fertilization during heat stress (Tawfik and Palta, 1992b). Our results suggest that maintaining a certain $\mathrm{Ca}^{2+}$ level during heat stress is essential for normal stomatal function. Additionally, plasma membrane $\mathrm{H}^{+}$-ATPases are one of the effectors of stomatal opening (see Kearns and Assmann, 1993) and their activity is regulated by Ca-stimulated protein kinase (Schaller and Sussmann, 1987). Thus, $\mathrm{Ca}^{2+}$ possibly can regulate stomatal function by regulating $\mathrm{H}^{+}$-ATPase activity in the guard cells. If this is true, then, by maintaining a certain $\mathrm{Ca}$ level in the guard cell, it may be possible to maintain normal stomatal functioning, which, in turn, would allow plants to avoid heat stress effects by dissipating heat through transpiration.

\section{Literature Cited}

Arora, R. and J.P. Palta. 1986. Protoplasmic swelling as a symptom of freezing injury in onion bulb cells. Its stimulation in extracellular $\mathrm{KCl}$ and prevention by calcium. Plant Physiol. 82:625-629.

Arora, R. and J.P. Palta. 1988. In vivo perturbation of membrane-associated calcium by freeze-thaw stress in onion bulb cells. Simulation of this perturbation in extracellular $\mathrm{KCl}$ and alleviation by calcium. Plant Physiol. 87:622-628.

Arora, R. and J.P. Palta. 1989. Perturbation of membrane calcium as a molecular mechanism of freezing injury, p. 281-290. In: J.H. Cherry (ed.). Environmental stress in plants. NATO Advanced Sci. Inst. Series, G 19. Springer-Verlag, Berlin.

Arora, R. and J.P. Palta. 1991. A loss in the plasma membrane ATPase activity and its recovery coincides with incipient freeze-thaw injury and post-thaw recovery in onion bulb scale tissue. Plant Physiol. 95:846-852.

Benoit, G.R., C.D. Stanley, W.J. Grant, and D.B. Torrey. 1983. Potato top growth as influenced by temperatures. Amer. Potato J. 60:489-501.

Bodlaender, K.B.A. 1963. Influence of temperature, radiation and photoperiod on development and yield, p. 199-201. In: J.D. Ivins and F.L. Milthorpe (eds.). The growth of the potato. Butterworths, London.

Burton, W.G. 1989. The potato. Longman Scientific \& Technical, Singapore.

Clarkson, D.T. 1984. Calcium transport between tissues and its distribution in the plant. Plant Cell Environ. 7:449-456.

Collier, G.F., D.C. Wurr, and V.C. Huntington. 1978. The effect of calcium nutrition on the incidence of internal rust spot in the potatoes. J. Agr. Sci. 91:241-243.

Cooke, A., A. Cookson, and M.J. Earnshaw. 1986. The mechanism of action of calcium in the inhibition of high temperature-induced leakage of betacyanin from beet root discs. New Phytologist 102:491-497.

Cramer, G.R., A. Lauchli, and V.S. Polito. 1985. Displacement of $\mathrm{Ca}^{2+}$ by $\mathrm{Na}^{2+}$ from the plasmalemma of root cells. Plant Physiol. 79:207-211.

Dhindsa, R.S. and A.F. Monroy. 1994. Low temperature signal transduction, gene expression, and cold acclimation: Multiple roles of low temperature, p. 501-514. In: J.H. Cherry (ed.). Biochemical and cellular mechanisms of stress tolerance in plants. NATO Advanced Sci. Inst. Series, H86. SpringerVerlag, Berlin.

Ewing, E.E. 1981. Heat stress and the tuberization stimulus. Amer. Potato J. $58: 31-49$

Gomez-Lepe, B.E., O.Y. Lee-Stadelmann, J.P. Palta, and E.J. Stadelmann. 1979. Effects of octylguanidine on cell permeability and other protoplasmic properties of Allium cepa epidermal cells. Plant Physiol. 64:131-138.

Hanson, J.B. 1984. The function of calcium in plant nutrition, p. 149-208. In: P.B. Tinker and A. Lauchli (eds.). Advances in plant nutrition. Praeger, New York.

Irving, H.R., C.A. Gehring, and R.W. Parish. 1992. Changes in cytosolic pH and calcium of guard cells precede stomatal movements. Proc. Natl. Acad. Sci. USA 89:1790-1794.

Kearns, E.V. and S.M. Assmann. 1993. The guard cell-environment connection. Plant Physiol. 102:711-715.

Khedher, M. and E. Ewing. 1985. Growth analyses of eleven potato cultivars grown in the greenhouse under long photoperiod with and without heat stress. Amer. Potato J. 62:537-554.

Kirby, E.A. and D.J. Pilbeam. 1984. Calcium as a plant nutrient. Plant Cell Environ. 7:397-405.

Kratzke, M.G. and J.P. Palta. 1985. Evidence for the existence of functional roots on potato tubers and stolons: Significance in water transport to the tuber. Amer. Potato J. 62:227-236.

Kratzke, M.G. and J.P. Palta. 1986. Calcium accumulation in potato tubers: Role of the basal roots. HortScience 21:1022-1024.

Legge, R.L., E. Thompson, J.E. Baker, and M. Lieberman. 1982. The effect of calcium on the fluidity and phase properties of microsomal membranes isolated from postclimacteric Golden Delicious apples. Plant Cell Physiol. 23:161-169.

Leonard, R.T. and P.K. Hepler. 1990. Calcium in plant growth and development. Amer. Soc. Plant Physiol., Rockville, Md.

Manrique, L. 1990. Growth and yield of potato grown in the greenhouse during summer and winter in Hawaii. Commun. Soil Sci. Plant Anal. 21:237-249.

McGuire, R.G. and A. Kelman. 1984. Reduced severity of Erwinia soft rot in potato tubers with increased calcium content. Phytopathology 74:12501256.

McGuire, R.G. and A. Kelman. 1986. Calcium in potato tuber cell walls in relation to tissue maceration by Erwinia carotovora pv. atroseptica. Phytopathology 76:401-406.

Midmore, D.J. and R.K. Prange. 1992. Growth responses of two Solanum species to contrasting temperatures and irradiance levels: Relation to photosynthesis, dark respiration and chlorophyll fluorescence. Ann. Bot. 69:13-20.

Monroy, A.F., F. Sarhan, and R.S. Dhindsa. 1993. Cold-induced changes in freezing tolerance, protein phosphorylation, and gene expression. Plant Physiol. 102:1227-1235.

Palta, J.P., H.H. Chen, and P.H. Li. 1981. Relationship between heat and frost resistance of tuber-bearing Solanum species: Effect of cold acclimation on heat resistance. Bot. Gaz. 142(3):311-315.

Palta, J.P. and O.Y. Lee-Stadelmann. 1983. Vacuolated plant cells as ideal osmometer: Reversibility and limits of plasmolysis, and estimation of protoplasm volume in control and water-stress-tolerant cells. Plant, Cell Environ. 6:601-610.

Palta, J.P., J. Levitt, and E.J. Stadelmann. 1977a. Freezing injury in onion bulb cells: I. Evaluation of the conductivity method and analysis of ion and sugar efflux from injured cells. Plant Physiol. 60:398.

Palta, J.P., J. Levitt, and E.J. Stadelmann. 1977b. Freezing injury in onion bulb cells: A comparison of freezing vs. desiccation and living vs. dead cells. Physiol. Plant. 41:273-279.

Palta, J.P. and P.H. Li. 1978. Cell membrane properties in relation to freezing injury, p. 93-115. In: P.H. Li and A. Sakai (eds.). Plant cold hardiness and freezing stress. Mechanisms and crop implications. Academic, New York.

Palta, J.P. and P.H. Li. 1980. Alterations in membrane transport properties by freezing injury in herbaceous plants. Evidence against rupture theory. Physiol. Plant. 50:169-175.

Pomeroy, M.K. and C.J. Andrews. 1985. Effect of low temperature and calcium on survival and membrane properties of isolated winter wheat cells. Plant Physiol. 78:484-488.

Poovaiah, B.W. and A.S.N. Reddy. 1987. Calcium messenger systems in plants. CRC Crit. Rev. Plant Sci. 6:47-102.

Poovaiah, B.W. and A.S.N. Reddy. 1993. Calcium and signal transduction in plants. CRC Crit. Rev. Plant Sci. 12(3):185-211. 
Schaller, G.E. and M.R. Sussmann. 1987. Kinase-mediated phosphorylation of the oat plasma membrane $\mathrm{H}^{+}$-ATPase, p. 419-429. In: C.J. Leaver and $\mathrm{H}$. Sze (eds.). Plant membranes: Structure, function and biogenesis. Alan R. Liss, New York.

Schwartz, A., N. Ilan, and D.A. Grantz. 1988. Calcium effects on stomatal movement in Commelina communis L. Use of EGTA to modulate stomatal response to light, $\mathrm{KCl}$ and $\mathrm{CO}_{2}$. Plant Physiol. 87:583-587.

Simmons, K.E. and K.A. Kelling. 1987. Potato responses to calcium application in several soil types. Amer. Potato J. 64:119-136.

Simmons, K.E., K.A. Kelling, R.P. Wolkowski, and A. Kelman. 1988. Effect of calcium source and application method on potato yield and cation composition. Agron. J. 80:13-21.

Steffen, K.L., R.M. Wheeler, R. Arora, J.P. Palta, and T.W. Tibbits. 1995 Balancing photosynthetic light-harvesting and light-utilization capacities in potato leaf tissue during acclimation to different growth temperatures. Physiol. Plant. 93:51-56.
Steward, F., U. Moreno, and W. Roca. 1981. Growth, form and composition of potato plants as effected by environment. Ann. Bot. 48:1-48.

Struckmeyer, B.E. and J.P. Palta. 1986. Anatomical evidence for the existence of roots on potato tubers and stolons. Amer. Potato J. 63:57-60.

Tawfik, A.A. and J.P. Palta. 1992a. Practical means of enhancing tuber calcium content and reducing incidences of soft rot and internal brown spot by application of soluble form of calcium during bulking. HortScience 27:665.

Tawfik, A.A. and J.P. Palta. 1992b. Mitigation of heat stress effects on potato growth by calcium and nitrogen application during stress. HortScience 27:596.

Toprover, Y. and Z. Glinka. 1976. Calcium ions protect beet root cell membranes against thermally induced changes. Physiol. Plant. 37:131-134.

Tzeng, K.C.A., A. Kelman, K.E. Simmons, and K.A. Kelling. 1986. Relationship of calcium nutrition to internal brown spot of potato tubers and subapical necrosis of sprouts. Amer. Potato J. 63:87-97.

Varns, J.L., L.A. Schaper, and D.A. Peterson. 1985. Potato losses during the first three months of storage for processing. Amer. Potato J. 62:91-99. 